GEAP- 10058

AEC RESEARCH AND

DEVELOPMENT REPORT

JULY 1969

\title{
CONCEPTUAL DESIGN STUDY OF AXIAL FUEL COOLING HARDWARE FOR THE FAST FLUX TEST FACILITY \\ FUEL EXAMINATION FACILITY
}

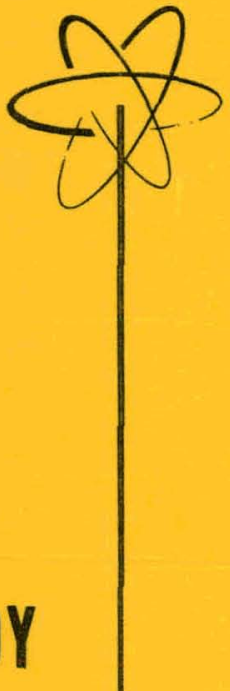

BY

J.H. GERMER

PREPARED FOR THE U.S. ATOMIC ENERGY COMMISSION UNDER CONTRACT NUMBER BDR-341 BETWEEN PACIFIC NORTHWEST LABORATORY AND THE GENERAL ELECTRIC COMPANY 


\section{DISCLAIMER}

This report was prepared as an account of work sponsored by an agency of the United States Government. Neither the United States Government nor any agency Thereof, nor any of their employees, makes any warranty, express or implied, or assumes any legal liability or responsibility for the accuracy, completeness, or usefulness of any information, apparatus, product, or process disclosed, or represents that its use would not infringe privately owned rights. Reference herein to any specific commercial product, process, or service by trade name, trademark, manufacturer, or otherwise does not necessarily constitute or imply its endorsement, recommendation, or favoring by the United States Government or any agency thereof. The views and opinions of authors expressed herein do not necessarily state or reflect those of the United States Government or any agency thereof. 


\section{DISCLAIMER}

Portions of this document may be illegible in electronic image products. Images are produced from the best available original document. 
GEAP-10058

AEC Research and

Development Report

July 1969

NOTICE

This report was prepared as an account of work sponsored by the United States Government. Neither the United States nor the United States Atomic Energy Cominission, nor any of their employees, nor any of their contractors, subcontractors, or their employees, makes any warranty, express or implied, or assumes any legal liability or responsibility for the accuracy, com. pleteness or usefulness of any information, apparatus, plereness or usefulness of any informeston, would not infringe privately owned rights.

\section{CONCEPTUAL DESIGN STUDY OF AXIAL FUEL COOLING HARDWARE} FOR THE FFTF FUEL EXAMINATION FACILITY

\section{J. H. Germer}

Approved:

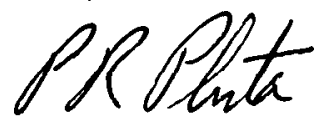

P. R. Pluta

Project Engineer
Approved:

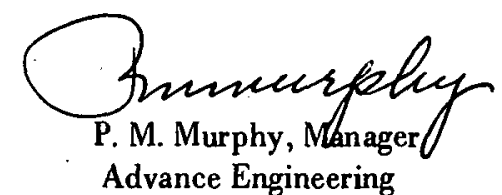

Advance Engineering

Prepared for the

U. S. Atomic Energy Commission

Under Conlract Number BDR-341

Between Pacific Northwest Laboratory

and the General Electric Company

Printed in U.S.A. Available from tbe

Clearing House for Federal Scientific and Tecbnical Information

National Bureau of Standards, U.S. Department of Commerce

Springfield, Virginia

Price: $\$ 3.00$ per copy 


\section{LEGAL NOTICE}

This roport wes proparod as an sosount of Covornmont sponsored work. Neitber the United States, nor the Commission, nor any person acting on bebalf of the Commission:

A. Makes any warranty or representation, expressed or implied, with respect to the accuracy, completeness, or usefulness of the information contained in this report, or that the use of any information, apparatus, method, or process disclosed in this report may not infringe privately owned rights; or

B. Assumes any liabilities with respect to the use of, or for damages resulting from the use of any information, apparatus, metbod, or process disclosed in this report.

As used in the above, "person acting on behalf of the Commission" includes any employee or contractor of the Commission, or employee of such contractor, to the extent that sucb employee or contractor of the Commission, or employee of such contractor prepares; disseminates, or provides access to, any information pursuant to bis employment or contract with the Commission, or bis emplovment with such contractor. 
TABLE OF CONTENTS

Introduction .................... 1 .1

1. Functions and Design Requirements . . . . . . . . . . 1.1

1.1 Functions ........................ 11

1.2 Design Requirements _. . . . . . . . . . . . . . . . $1-2$

2. Physical Description of the System . . . . . . . . . . . 2-1

2.1 Summary Description . . . . . . . . . . . . . . 2-1

2.2 Detailed Description $\ldots \ldots \ldots \ldots$

3. Safety Consideration . . . . . . . . . . . . . . 31

3.1 Hazards . . . . . . . . . . . . . . . . . . . $3-1$

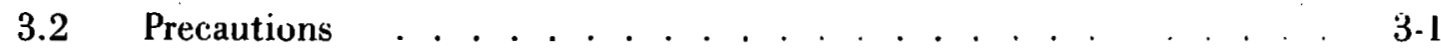

4. Principles of Operation . . . . . . . . . . . . . 4.1

4.1 Description of Driver Fuel Transfer _. . . . . . . . . . . . 4-1

4.2 Description of Open Loop Fuel Transfer . . . . . . . . . . . . . 4.4

4.3 Transfer in the Cell . . . . . . . . . . . . . . . . . . . . 44

5. Maintenance Principles . . . . . . . . . . . . . 5 5-1

\section{APPENDIX}

A. Alternate Cooling Methods . . . . . . . . . . . A-1

B. Substitutes for Suction Hose $\quad \ldots \ldots \ldots \ldots$ B.1

C. Pumping System Analysis . . . . . . . . . . . . . . . . C.1

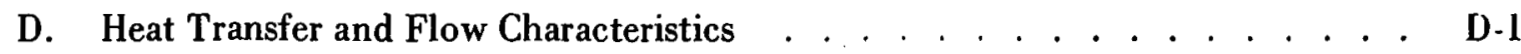

E. Heat Transfer and Flow Calculations _. . . . . . . . . . E-1

F. Emergency Cooling by Radiation . . . . . . . . . . F-1 
TABLE OF CONTENTS (Continued)

(;. Fuel Disassembly Station . . . . . . . . . . . . . . . . G-1

H. Development Program ...... . . . . . . . . . . . . . . . . . . H-1

1. Instrumentation . . . . . . . . . . . . . . . . . . I-1

J. Related Experience in Gas Cooling . . . . . . . . . . . . . . . . J-1

K. Interfaces .......................... . . . . . .

Acknowledgments . . . . . . . . . . . . . . . . - 1 -

Distribution ...................... . . 1- 
GEAP-10058

\section{LIST OF ILLUSTRATIONS}

Figure

Title

Page

2-1 Axial Gas Cooling-Gen. Arrangement . . . . . . . . . . . . . . . 2-2

2 Axial Gas Cooling System . . . . . . . . . . . . . . . 2-3

$2-3$ Suction Manifold and Transfer Port . . . . . . . . . . . . . . 24

4-1 . Entry of Fuel Assembly into Fuel Transfer Cell _ . . . . . . . . . . . . . . . 4-2

4 Transfer to $\mathrm{G}$ as Cooling . . . . . . . . . . . . . . . . 4 4 . . . .

4-3 Sodium to Gas Cooling Sequence for Driver Fuel $\ldots \ldots \ldots \ldots$

4.4 Driver Fuel Sodium-Gas Interface . . . . . . . . . . . . . . . . . . . . . . . . 4-7

4-5 Sodium to Gas Cooling Sequence for Open Loop _ . . . . . . . . . . . . . . . 449

4-6 Driver Fuel Axial Gas Cooling Transfer Sequence . . . . . . . . . . . . . 4-11

4-7 Temporary Gas Cooled Fuel Storage . . . . . . . . . . . . . . 4 4-12

A-1 Na to Gas Transfer Sequence . . . . . . . . . . . . . . A-3

B-1 Articulated Suction Tube . . . . . . . . . . . . . . B-2

C-1 Isentropic Pumping Power and Pump Outlet Temperature Versus Pressure Rise . . . . . C-2

C-2 Two Stage Pumping Power and Pump Outlet Temperature Versus Pressure Rise and Pump Efficiency . . . . . . . . . . . . . . . C C-3

C-3 Two Stage Pumping Power Versus Pressure Rise and Leakage Flow . . . . . . . . C-4

C-4 Temperature Versus Entropy . . . . . . . . . . . . . C-5

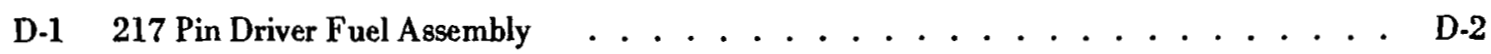

D-2 Wall Temperature as a Function of Pressure Drop for Downward Suction . . . . . . . D-3

D-3 Coolant Outlet Temperature as a Function of Pressure Loss for Downward Suction . . . D-4

D-4 Coolant and Wall Temperatures as a Function of Axial Position for Downward Flow . . . D-5

D-5 Mass Flow Rate for Downward Suction as a Funcliun of Pressure Loss . . . . . . . D-7

D-6 Exit MACH Number as a Function of Mass Flow Rate for Downward Suction $\quad \ldots \quad \ldots \quad$ D-8

D-7 Wall, Coolant, and Stagnation Temperatures for Downward Suction _ . . . . . D D

D-8 Wall Temperature as a Function of Pressure Loss for Downward Blowing . . . . . . D-10 


\section{LIST OF ILLUSTRATIONS (Continued)}

Figure

Title

Page

D-9 Coolant Exit Temperature as a Function of Pressure Loss for Downward Blowing . . . . D-11

D-10 MACH Number as a Function of Mass Flow Rate for Downward Blowing . . . . . . . D-12

D-11 Wall and Coolant Temperatures for Upward Suction . . . . . . . . . . D-12

E-1 Fuel Bundle Schematic . . . . . . . . . . . . . . E-5

F-1 Center Rod Temperature in a Hexagonal Bundle (217 Rods) Cooled Only

by Radiation . . . . . . . . . . . . . . . . . . . . . . F-2

F-2 Radial Temperature Profiles in a 217 Pin Hexagonal Bundle Cooled Only by Radiatiun . . . . . . . . . . . . . . . . . . F-3.

G-1 Method for Utilizing Suction Manifold for Providing Down Flow Cooling During Removal of Shroud . . . . . . . . . . . . . . . . . . G-2

I-1 Added Flow Baffle in Suction Manifold to Permit Accurate Measurement of Outlet Temperature . . . . . . . . . . . . . . . . . I-2

\section{LIST OF TABLES}

Tablc

Title

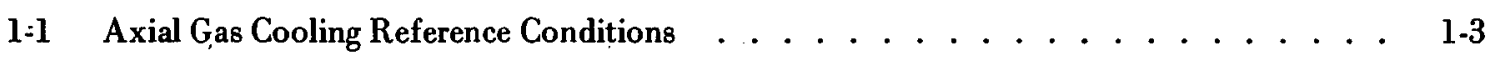

2-1 Characteristics of Pumping System . . . . . . . . . . . . . . . . 2-5

$2-2$ Instrument Types and Location . . . . . . . . . . . . . . . . . . 26

E-1 Variables Which May Be Read From The Data File In MACH _ . . . . . . . . E E

H-1 Estimated Financial and Manpower Needs for FFTF Fuel Cooling Station R \& D . . . . H-2

H-2 Schedule for FFTF Fuel Cooling Station Equipment R \& D . . . . . . . . . H-3

I-1. Approximate Readings of Instruments Under Various Normal and Abnormal Conditions . . I-1 


\section{INTRODUCTION}

A redirected scope of work under contract BDR-341 was ayreed upon between Battelle Northwest Laboratories and General Electric Company in February 1969 to support the new open lattice, vertical reference core concept described in BNWL-955 FFTF Reference Concept Summary Description (January 1969). The new scope of work consisted of four diverse engineering tasks to be completed in the period of February through June 1969. The other tasks are reported in the following documents:

\section{- GEAP-10059}

An Analytical Evaluation of the Consequence of a Hypothetical Instantaneous Loss of Coolant Flow to a Fast Flux Test Facility Driver Fuel Assembly, L. M. McWethy, (July 1969)

\section{- GEAP-10056}

Conceptual Design Study of Dynamic Sealing Techniques Applicable to the Fast Flux Test Facility Control Rod Drive Mechanism, R. W. Lockhart and P. M. Tschamper, (July 1969)

\section{- GEAP-10057}

Design Considerations for the Operation of the Fast Flux Test Facility With Fuel Fission Gas Emission, W. R. Gee (July 1969)
This report is in the general format* of a Conceptual System Design Description, defined by BNWL-592 as specified in the statement of work for this task in contract BDR-34l.

The objective of this study is to provide the conceptual design of an in-cell argon gas-cooling system and associated equipment required to remove up to $20 \mathrm{~kW}$ of decay heat from FFTF driver and test fuel assemblies during transfer, disassembly, and examination operations within the fuel examination facility. ${ }^{*}$ The scope includes the removal of the fuel assembly from a sodium-filled transfer pot and a definition of the other interface requirements with equipment that is directly involved with fuel transfer. Design study of the gas circulating system is limited to a preliminary concept of the system, but does not include detailed sizing of the components. The study recommendations should be compatiable with the Inert Gas Cell Examination Facility as described in BNWL-500.**

A detailed analysis of the flow and temperature relationships in the gas-cooled fuel is included in Appendix D and Appendix E. A proposed development program is given in Appendix $\mathrm{H}$, along with estimated costs and schedule. A brief description of past experience in the handling of fast reactor fucl under gas cooling is given in Appendix $J$.

\section{Section 1.0 FUNCTIONS AND DESIGN REQUIREMENTS}

\subsection{FUNCTIONS}

The primary function of the axial fuel cooling hardware is to provide cooling of an irradiated FTR fuel assembly during transfer operations within the Examination Facility. Three basic types of assemblies are to be cooled by the device: (a) a driver fuel assembly, (b) an open loop test assembly, (c) a closed loop test assembly. The two types of test assemblies differ from the driver assembly in having long instrumentation extensions at their upper ends.

Specific fuel assembly handling operations to be accommodated are as follows:

- Removal from and transfer to a sodium-filled transfer pot

- Transfer to and from a gas-cooled temporary storage station

- Transfer to and from a fuel-cleaning station
- Transfer to and from a neutron radiography station

- Cooling during neutron radiography

- Transfer to and from a gamma scanning station

- Cooling during gamma scanning

- Transfer to and from a fuel disassembly - reassembly station

- Transfer to a final disposal station.

* Dulin, R. V., "Instruction Design Description Preparation," Pacific Northwest Laboratory, October 1967. (BNWL-592).

* Ramsey, E. B. and Meyers, D. J., "Conceptual Facility Design Description for the Inert Gas Cell Examination Facility" December 1968, (BNWL-500, Vol. 71). 


\subsection{DESIGN REQUIREMENTS}

\subsubsection{BASIC DESIGN REQUIREMENTS}

Equipment shall be provided for forced gas cooling of fuel specimens to about $600^{\circ} \mathrm{F}$ cladding temperature (higher cladding temperatures could be tolerated in specific tests) during handling, examination and storage. Total heat removal capability (heat removal capability depends upon fuel subassembly design, permissible cladding temperature, allowable drag or vibration forces and decay heat output per fuel pin) for a fuel subassembly will be:

- Up to $20 \mathrm{~kW}$ for forced gas cooling with axial flow.

Equipment for forced gas coulling shall be instrumentod to monitor:

- Flowrate

- Pressure drop

- Irlet gas temperature

- Outlet gas temperature.

Instrumentation shall be provided to monitor cladding temperature of fuel test pins that are instrumented with surface thermocouples.

Fuel cladding temperatures shall be controlled by varying the cooling gas flowrate within limits determined by:

- Calculated flowrate and outlet temperature for specified cladding temperature.

- Signal from a surface thermocouple on an instrumented test pin.

Maximum surface temperature of the cladding shall be limited to not more than $600^{\circ} \mathrm{F}$ during normal transfor operation of a fuel assembly generating $20 \mathrm{~kW}$ of heat. Heat transfer and flow characteristics are discussed in Appendix $D$, with the analytical method discussed in Appendix E.

Maximum surface temperature of the cladding shall be limited to $1500^{\circ} \mathrm{F}$ under emergency conditions.

Instrumentation will be provided to indicate and permit locating the source of any malfunction of the cooling device.

The design of the axial fuel cooling hardware must be compatible with the following stations, and the cooling device must be capable of receiving a fuel bundle from the station or transferring a fuel bundle to the station:

- Gas-cooled storage station
- Cleaning station

- Neutron radiography station

- Gamma-scanning station

- Disassembly - reassembly station (see also Appendix G)

The design of the axial gas cooling, device must be compatible with the fuel transfer device, and capable of transferring a fuel bundle to and from a liquid sodium-filled pot in the fuel transfer device. Appendix $K$ described equipment interfaces.

The axial gas cooling device must be able to cool the following fucl agsemblioo: *

- Driver fuel assembley

- Open loop test assembly

- Closed loop test assembly

The in-cell portion of the equipment must be capable of operatıng in a high radiation inert gas environment under conditions of residual sodium, sodium vapor, and high radiant heat.

Equipment or methods shall be provided to control the deposition of sodium vapor on in-cell surfaces and equipment.

$\Lambda$ n emergency backup conling method müst be provided independent of the normal fuel cooling systêm in order to prevent fuel meltdown during transfer and examination operations.

Reliable, low maintenance operation shall be a prime requirement.

Instrumentation will be provided to monitor and control fuel subassembly cooling systems at all times systems are in use.

In-cell equipment shall be designted fur seinote removal and replacement or remote maintenance. Refer to Appendix K for equipment interfaces.

\subsubsection{FIRM DESIGN CHOICES}

Coolant flow through the fuel assembly during all transfer operations will be in the downward direction, with argon

* Walker, R. C., "FFTF Reference Concept Summary Description"'January 1969, (BNWL-955). 
inlet gas at cell conditions entering the top of the fuel assembly. (Cell conditions are assumed to be 14.6 psia and $\left.100^{\circ} \mathrm{F}.\right)$

Transfer of fucl out of a liquid sodium-filled pot will be done with the fuel assembly uncooled during the time of transfer.

Connection of the gas suction system cooling manifold to the fuel bundle will be by means of a flexible hose near floor level.
Transfer of fuel over a distance greater than can be arcommodated by the length of the flexible hose will br arcomplished by first transferring to a temporary cooling station. At this time the hose can be disconnected and reconnected to a different outlet before continuing the transfer.

Reference conditions for the axial gas cooling of driver fuel assemblies are tabulated in Table 1-1.

Alternates to the above firm design choices are discussed in Appendix A.

Table 1-1

AXIAL GAS COOLING REFERENCE CONDITIONS

HEAT GENERATED . . . . . . . . . . . . . . $20 \mathrm{~kW}$

INLET PRESSURE . . . . . . . . . . . . . . . . . . . . . . . . . . . . . . psia (cell atmosphere)

FUEI ASSEMBLY OUTLET PRESSURE . . . . . . . . . . . . 12.5 psia

PRESSURE AT DOWNSTREAM END OF HOSE $\ldots . . . \quad . \quad . \quad . \quad .11 .5$ psi

GAS - argon

GAS FLOW RATE THROUGH FUEL ASSEMBI.Y $.210 \mathrm{ft}^{3} / \mathrm{min}^{*}$

ASSUMED LEAKAGE GAS FLOW . . . . . . . . . . . . . . . $42 \mathrm{ft}^{3} / \mathrm{min}^{*}$

TOTAL GAS FLOW . . . . . . . . . . . . . . . . . $252 \mathrm{ft}^{3} / \mathrm{min}^{*} \quad 25 \mathrm{lb} / \mathrm{min}$

INLET TEMPERATURE . . . . . . . . . $100^{\circ} \mathrm{F}$

FUEL ASSEMBLY OUTLET TEMPERATURE . . . . . . . . $5400^{\circ} \mathrm{F}$

MAXIMUM CLADDING SURFACE TEMPERATURE . . . . . $600^{\circ} \mathrm{F}$

TEMPERATURE IN SUCTION HOSE

No Leakage . . . . . . . . . . . . . . . . . $540^{\circ} \mathrm{F}$

Maximum Leakage . . . . . . . . . . . . . $466^{\circ} \mathrm{F}$

TEMPERATURE OF GAS RETURNED TO CELL . . . . . . . $90^{\circ} \mathrm{F}$

HEAT CAPACITY OF FUEL AND CLADDING . . . . . . . . $8.62 \mathrm{Btu} /{ }^{\circ} \mathrm{F} \quad 0.152 \mathrm{~kW} \min /{ }^{\circ} \mathrm{F}$

ȦVERAGE RATE OF TEMPERATURE RISE

WITH NO COOLING $(20 \mathrm{~kW}) \ldots . . . . . . . . .132{ }^{\circ} \mathrm{F} / \mathrm{min}$

PEAK RATE OF TEMPERATURE RISE

WTH NO COOLING $(20 \mathrm{~kW}) \ldots \ldots . \ldots . . . \ldots 158^{\circ} \mathrm{F} / \mathrm{min}$

ASSUMED TRANSFER POT SODIUM TEMPERATURE $\ldots . .400^{\circ} \mathrm{F}$

*Volume Calculated at 14.7 psia and $100^{\circ} \mathrm{F}$. 


\section{Section 2.0 PHYSICAL DESCRIPTION OF THE SYSTEM}

\subsection{SUMMARY DESCRIPTION}

Illustrated in Figure 2-1 is the arrangement of the fuel handling cell (location No. 1) and the fuel examination cell (No. 2). A fuel assembly is brought into the fuel transfer port (No. 4) in a sodium-filled pot by means of an indirect gas-cooled fuel handling machine. This machine (not shown) operates in a fuel transfer cell (No. 3) located at a lower level and receives fuel from the refueling machine and transfers fuel to the Fuel Transfer Cell.

A fuel assembly is removed from the sodium-filled pot and transfer is made in the fuel handling and fuel examination cells with the assistance of the axial gas cooling equipment described in detail in this report. Transfers are made to and from cleaning stations (No 8), gas-cooled storage stations (No. 7), temporary cooling station (No, 11), and the disassembly-reassembly machines (No. 12). Also transfers can be made to other stations which are not illustrated in Figure 2-1, to accomplish other functions such as gamma scanning and neutron radiography.

The cooling of a fuel assembly during transfer and during neutron radiography and gamma scanning examinations is shown schematically in Figure 2-2. The fuel assembly is carried by an overhead grapple between fixed stations. During transfer, the lower end of the fuel assembly is maintained at a negative pressure of about 3 psi, causing argon gas from the cell to enter the top of the assembly and leave at the bottom. The heated gas flows through the flexible hose into the primary system, which also cools and filters the gas.

In the detailed description of the axial gas cooling system. it is broken down into the following three components:

- A suction manifold, which is attached to the lower end of a fuel assembly after the fuel assembly is drawn through it.

- A gas pumping system located external to the fuel handling cell, including suction pumps, heat exchangers and a filter. This system receives hot argon gas at elevated temperature and reduced pressure. This argon may be contaminated with sodium vapor, particles of liquid sodium, or small radioactive particles of solid material from the fuel assembly. The system returns filtered argon to the cell at approximately the temperature of the cell and at atmospheric pressure.

- An interconnecting system consisting of fixed piping. valves, and a flexible hose. This connects the suction manifold to the gas pumping system.

\subsection{DETAILED DESCRIPTION}

\subsubsection{SUCTION MANIFOLD}

The suction manifold is shown in Figure 2-3. It is a portable unit which attaches to a flange at the upper end of the fuel transfer port. Three toggle clamps are utilized to hold it in place. The suction manifold can also attach to any one of various other flanges at other locations where fuel assembly transfer is to take place. Alignment with the flanges is accomplished by means of two alignment pins.

A suction hose connection is provided at the side of the suction manifold, with a disconnect coupling to permit changing hoses. The hose is attached to a swivel in order to permit rotation of the suction manifold with respect to the hose.

The upper part of the suction manifold is fitted with a hexagonal openıng through which the fuel assembly can be drawn. In order to provide sealing of this hexagonal opening onto the outside of a fuel assembly, it is made of sufficient length to $\times x t e n d$ between two adjacent raised pads on the fuel assembly (spaced 54.6 inches apart on the driver fuel assembly). A suggested means of sealing on this hexagonal surface is shown in Figure 2-3, although this is considered to be an area requiring development. Leakage through this seal can be permitted as long as sufficient pumping capacity is provided to maintain the required suction.

This hexagonal seal is designed as an insert which can be changed to accommodate different sized assemblies. When used with an instrumented test assembly, this insert is made in two parts to permit the large end flange of the fuel assembly to pass through the opening. The feature will be discussed in subsection 4.2. The suction shroud may be installed either before or after the fuel assembly is brought into the transfer port in its sodium-filled pot.

Two flexible cables connect between the grapple and the suction manifold to lift the suction manifold when fuel is being transferred and to prevent accidentally raising the fuel assembly out of the suction manifold. These cables are provided with windup reels to take up the slack when the fuel assembly is lowered.

\subsubsection{PUMPING SYSTEM}

The details of the pumping system are beyond the scope of this studv although the basic concepts will be discussed. The pumping system is located in a separate equipment room and is connected to the suction hose through fixed 
GEAP-10058

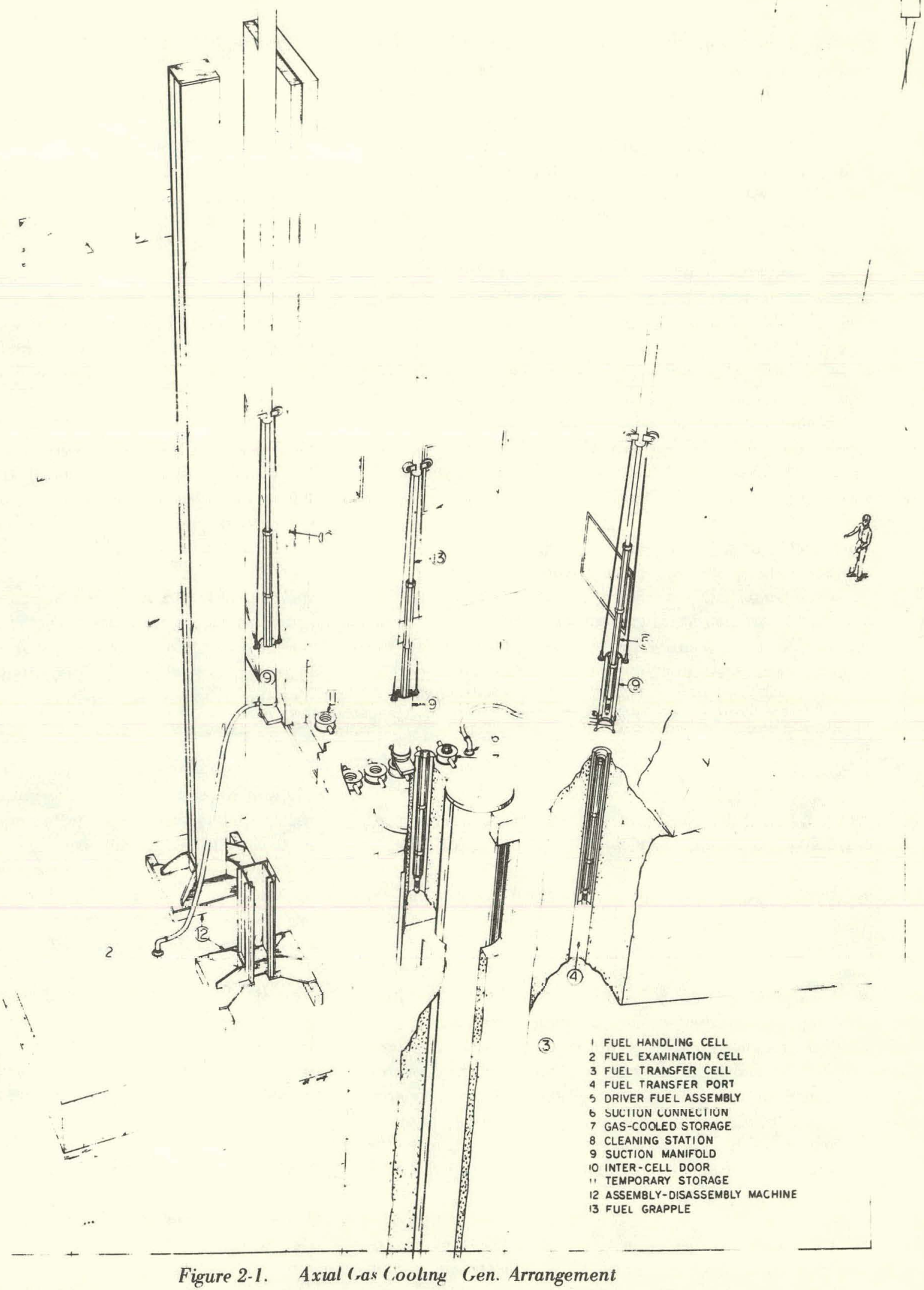




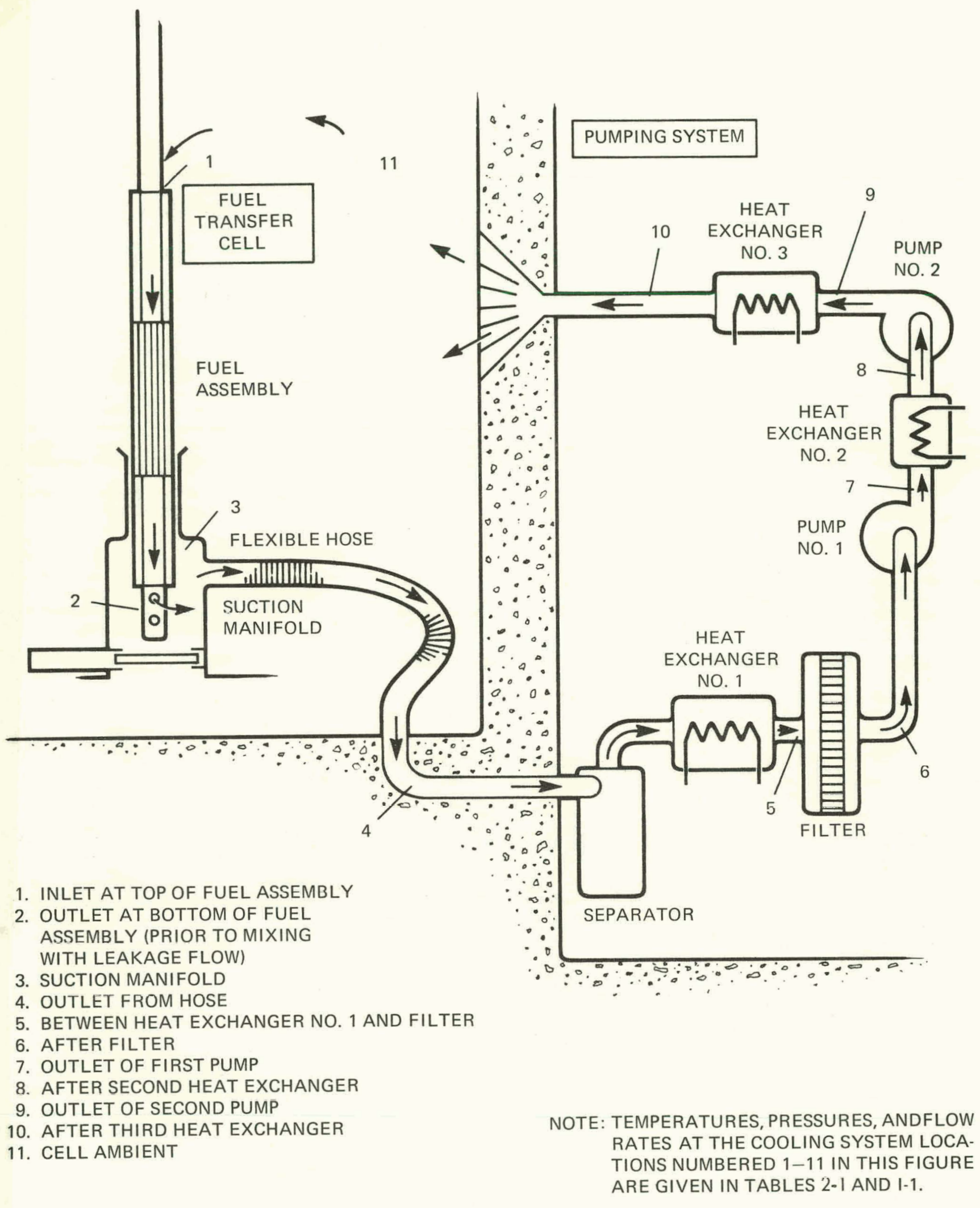

Figure 2-2. Axial Gas Cooling System 

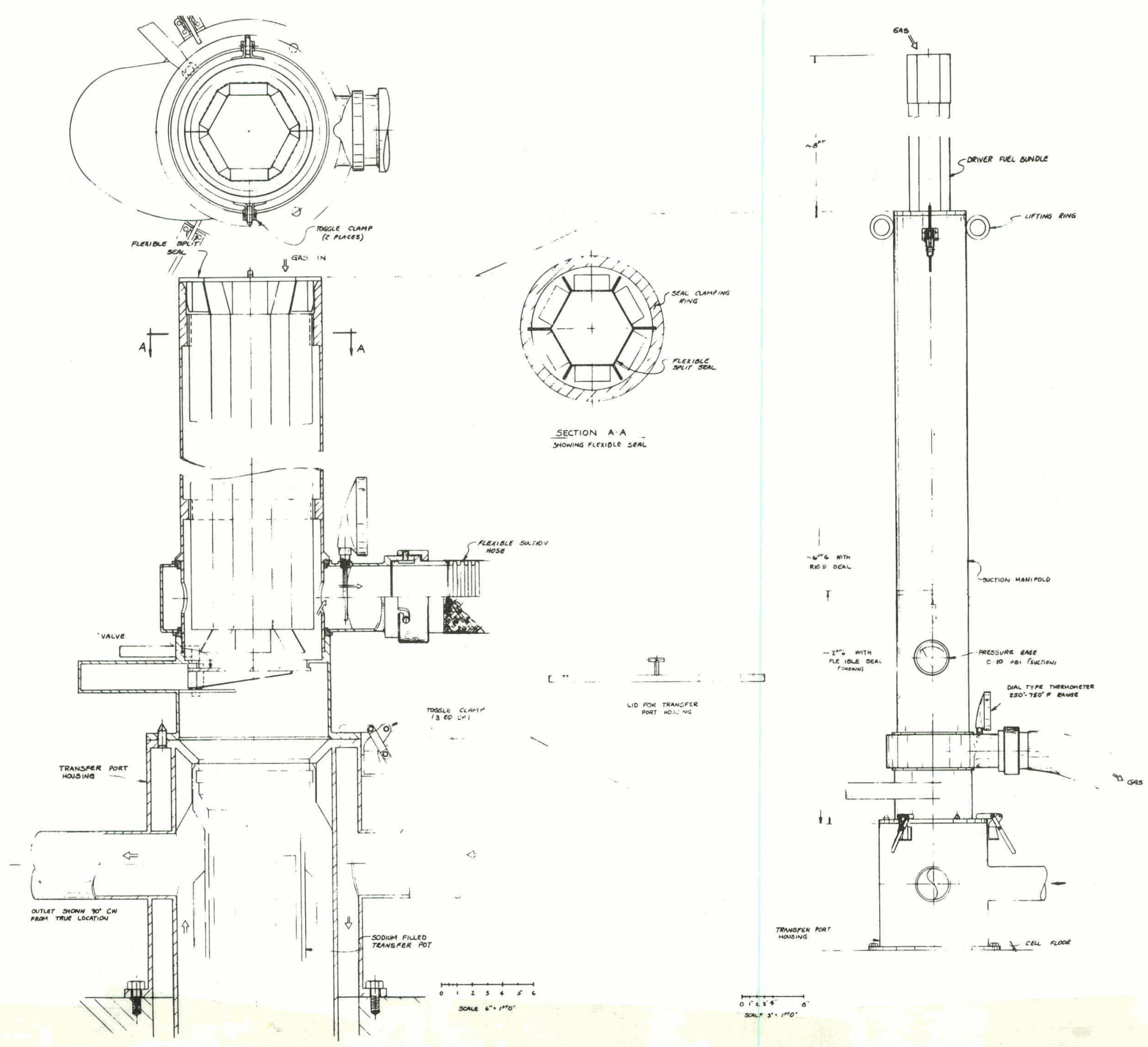

量

Figure 2-3. Suction Manifold and Transfer Port 
piping and suitable valving. The recommended system is shown schematically in Figure 2-2, and its characteristics are tabulated in Table 2-1.

The pumping is accomplished by two centrifugal blowers operating in series and driven by separate electric motors. Reliability is assured by providing independent electrical power circuits for the two blowers. Each blower has a shaft power of about 7.5 horsepower, assuming a $60 \%$ efficiency for the blower and a total pressure drop of $4.7 \mathrm{psi}$. In the event of failure of one unit, the second one will continue at somewhat over half of the rated flow without requiring any valve operation.

Heat exchangers are provided at the inlet to the system, hetween the two blowers, and at the exit to the second blowers. In each case the gas temperature is reduced to approximately $100^{\circ} \mathrm{F}$. A filter is located in the system immediately after the first heat exchanger to minimize the amount of particulate matter that could be blown back into the cell. Its location after the first heat exchanger assures low temperature operation of the filter. The other heal exchangers are required to remove the heat added by compression of the argon gas. A further discussion of the system is yiven in Appendix C.

A separator is provided before the first heat exchanger to trap out a large surge of liquid sodium that could be inadvertently sucked into the system if the suction system is started before complete withdrawal of the fuel assembly from the sodium. The volume of this separator should be approximately equal to that of the sodium-filled transfer pot. Provision should be made for removal of collected sodium.

\subsubsection{SUCTION HOSE}

The recommended suction hose is a flexible metallic braidcovered bellows-type stainless-steel hose, equivalent to Flexonics Series 400L/T-321. An inside diameter of 4 inches provides adequate flow area for suction cooling of a $20 \mathrm{~kW}$ fuel assembly. A nominal length of 12 feet is required to provide adequate access to the required locations in the cell. The concept would allow a considerably longer hose, if that should be determined to be desirable.

A disconnect coupling is provided at each end of the hose to permit connecting to suction ports at more than one location in the cell. It also makes it possible to replace the hose or to replace the suction manifold.

During operation, the hose at the suction manifold end remains between 2 and 3 feet above the floor, and the remainder of the hose rests upon the floor. The other end of the hose is provided with a swivel mounting to the connecting pipe at floor level. Alternates to this hose arrangement are discussed in Appendix B.

\subsubsection{INSTRUMENTATION}

Instrumentation is required for monitoring the operation of the gras cooling system and to ensure that the temperature limit of the fuel is not exceeded. Devices for measuring temperature, pressure, and flow are located at various points in the system. Their locations are based upon convenience of measurcment and usefulness of the measurements.

Table 2-1

\section{CHARACTERISTICS OF PUMPING SYSTEM}

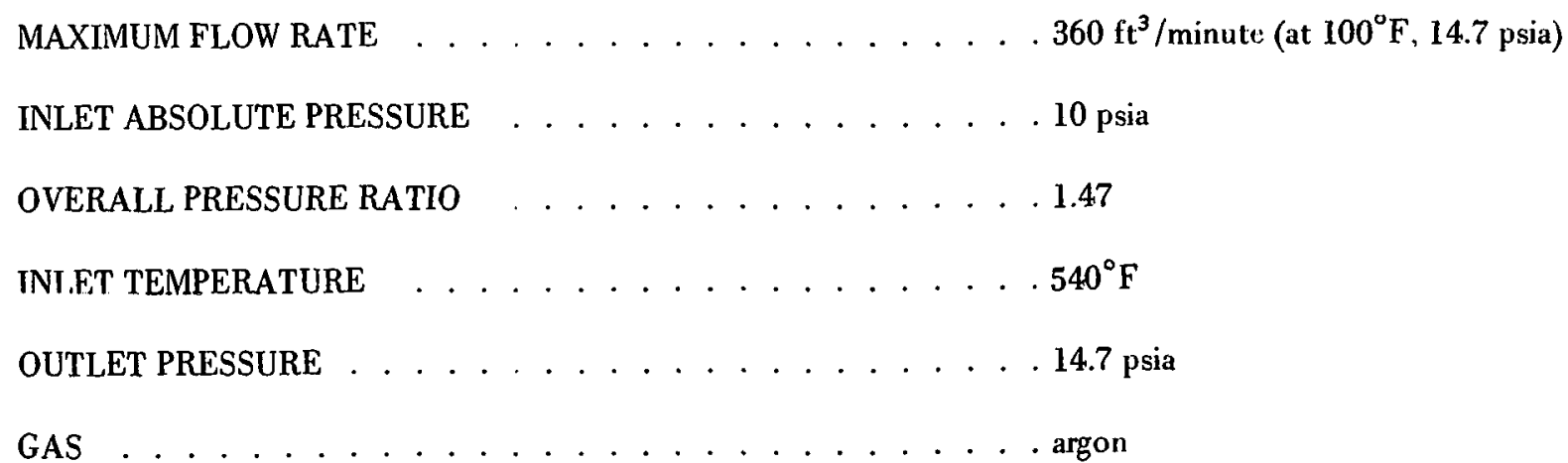

PUMPING METHOD ................... . . two independent centrifugal blowers in series

TOTAL BLOWER POWER (assuming $60 \%$ efficiency) $\ldots . . . .15$ horsepower 
The schematic of the pumping system, Figure 2-2, identifies 11 different locations for instruments. These locations are tabulated in Table 2-2. The table distinguishes between remote and direct reading instruments (indicated as " $R$ " and "D"). It also notes the desirability of instruments to mea- sure directly the flow at the top of the fucl ass:mbly (inlet) and the outlet temperature. These are not included in the reference, since these measurements would be very difficult to obtain. A further discussion of the instrumentation is given in Appendix I.

Table 2-2

\section{INSTR UMENT TYPES AND LOCATION}

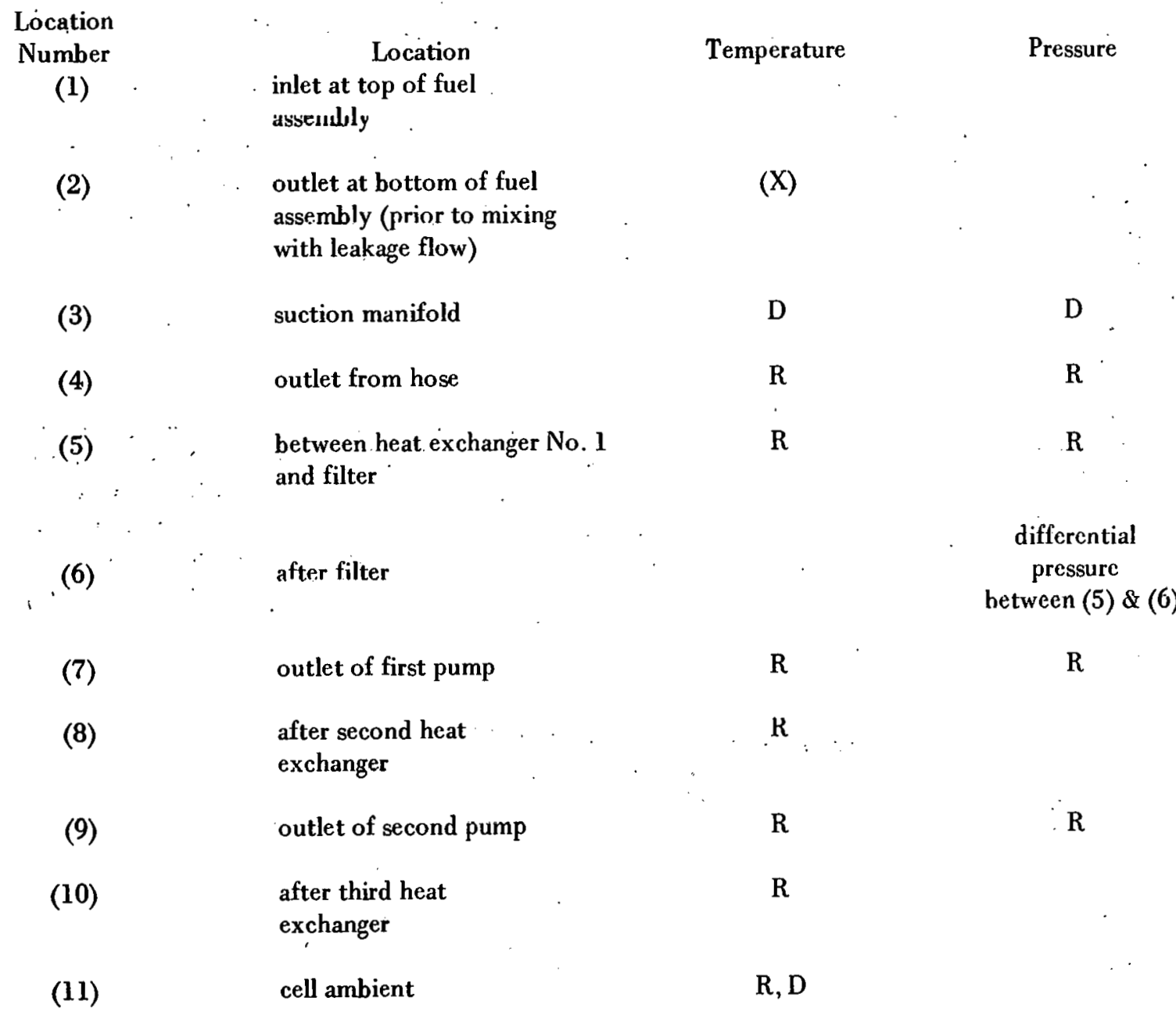




\section{Section 3.0 SAFETY CONSIDERATION}

\subsection{HAZARDS}

The primary hazard involved in the transfer of fuel is loss of coolant flow. In the case of driver fuel or an open loop fuel assembly, loss of coolant flow would eventually result in the melting of cladding and extreme contamination of the cell. Even assuming a very optimistic value of emissivity, the cladding will reach $1500^{\circ} \mathrm{F}$ with less than $5 \mathrm{~kW}$ of heat generation (see Appendix F). The possible causes for loss or reduction of coolant flow follow:

- Failure of the pumping system (including heat exchangers or pumps)

- Rupture of the hose

- Kinking of the hose

- Raising of the fuel assembly out of the top of the suction manifold

- Failure of wall of fuel assembly

- Failure of flexible hexagonal seal in suction manifold

- Partial flow blockage within the fuel bundle
Other failures, such as accidental dropping of the fuel assembly are not discussed here, since they are not considered as failure of the cooling device.

\subsection{PRECAUTIONS}

The following methods can be used to reduce the severity of a flow failure:

- Provide redundancy in the pumping system

- Transfer the fuel assembly to an emergency cooling station

- Provide a backup hose that can be connected within a few minutes

- Provide two independent cables to prevent raising the fuel assembly out of the suction manifold

- Provide adequate instrumentation for monitoring operation of the cooling system. 


\section{Section 4.0 PRINCIPLES OF OPERATION}

\section{I DESCRIPTION OF DRIVER FUEL TRANSFER}

lintry of a driver luel assembly into the cell is shown schenatically in Figures 4-1, 4-2. and 2-2. In Figure 4-1 is sliown the luel assembly raised into the transfer port and the suction manifold installed. 'The relationship after the l'url assimbly has bern grappled and raised until its lower end is above the gate valve of the suction manifold is indicated in Figure 4-2. At this time the suction has been initiated. The fuel assembly during transfer, with the gate valve closed, is shown in Figure 2-2.

This sequence is shown in more detail, and to approximate scale, in Figure 4-3. The following is a description of the eight sequence operations numbered on the drawing:

\section{- (1)}

The entrance port connecting the fuel transfer tunnel and the fuel handling cell is illustrated. A gas cooling system is provided for cooling the sodium-filled pot if it remains within the port. This cooling circuit is open to the cell, but otherwise is operated as a closed circuit. Its capacily should be sulficieril to move $20 \mathrm{~kW}$ of heat with a temperature rise of about $200^{\circ} \mathrm{F}$, requiring an argon flow of $460 \mathrm{ft}^{3} / \mathrm{min}$ (based on properties at 1 atm and $100^{\circ} \mathrm{F}$ ). The upper end of this port can be covered with a blind flange when not in use.

- (2)

This illustrates a fuel assembly and sodium-filled transfer pot inserted into the transfer port from the botlom. The pot is raised against a stop at the upper end by a mechanism which is not shown.

- (3)

The suction manifold is mounted in place on the upper flange of the transfer port. 'The gate valve at the lower end of the suction manifold remains open. A craneoperated grapple is then lowered through the suction manifold to attach to the fuel assembly. The fuel assembly is slowly raised until its upper end is engaged in the hexagonal seal section of the suction manifold. Rotation of the fuel assembly may br necessary to affect the engagement. Note that in this position the heat generating section of the fuel assembly is still below the level of the sodium.

- (4)

The grapple is raised within approximately one minute (so as to avoid exceeding cladding temperature limitations) until the bottom of the fuel assembly is above the gate valve in the suction manifold. Total time for this operation should be limited to approximately one min- ute to avoid excessive temperature rise. The suction system is now started, with argon from the cell passing downward through the fuel assembly. Excess sodium from the fuel assembly will tend to be blown downward into the transfer pot, but some will be carried with the argon stream. In the event that the fuel assembly becomes stuck at a position where part of the fuel is above the sodium level but the lower end is still below the sodium, the suction system will be started in any event. This will cause a considerable amount of sodium to be carried into the suction system, but cooling will be adequate. The suction system is designed to accommodate this sodium.

- (5)

After sufficient time to blow off most of the liquid sodium, the valve is clesed at the bottom of the suction manifold. Altur unclamping the flange, the fuel assembly is carried to another station along with the suction manifold.

- (6)

The features of a typical station are illustrated to which the fucl assembly can be transferred. In this case it is a gas-cooled storage station, although other stations will have similar cooling features. The flange of this station is similar to the one at the entrance port, and the suction manifold is clamped onto it. An independent suction system at the storage station is started up before opening the gate valve at the bottom of the suction shroud. The fuel assembly is now being cooled by both suction systems.

- (7)

The fuel assembly is now lowered until its lower fitting is engaged in a port at the bottom. At this point the portable suction system is blocked off (and indication of this is shown on its pressure gauge).

- (8)

The suction manifold will now be completely removed, leaving the fuel assembly in the gas-cooled storage station. Transfer of the fuel assembly out of this station is done by reversing the above procedure.

The raising of the fuel assembly out of the sodium-filled pot is shown in greater detail in Figure 4.4. The sodium pot and the suction manifold are shown in sequence No. 1 . The relative elevations of the fuel assembly and the sodium surface are shown separately in sequences No. 2 through No. 6. A description of this sequence is as follows: 


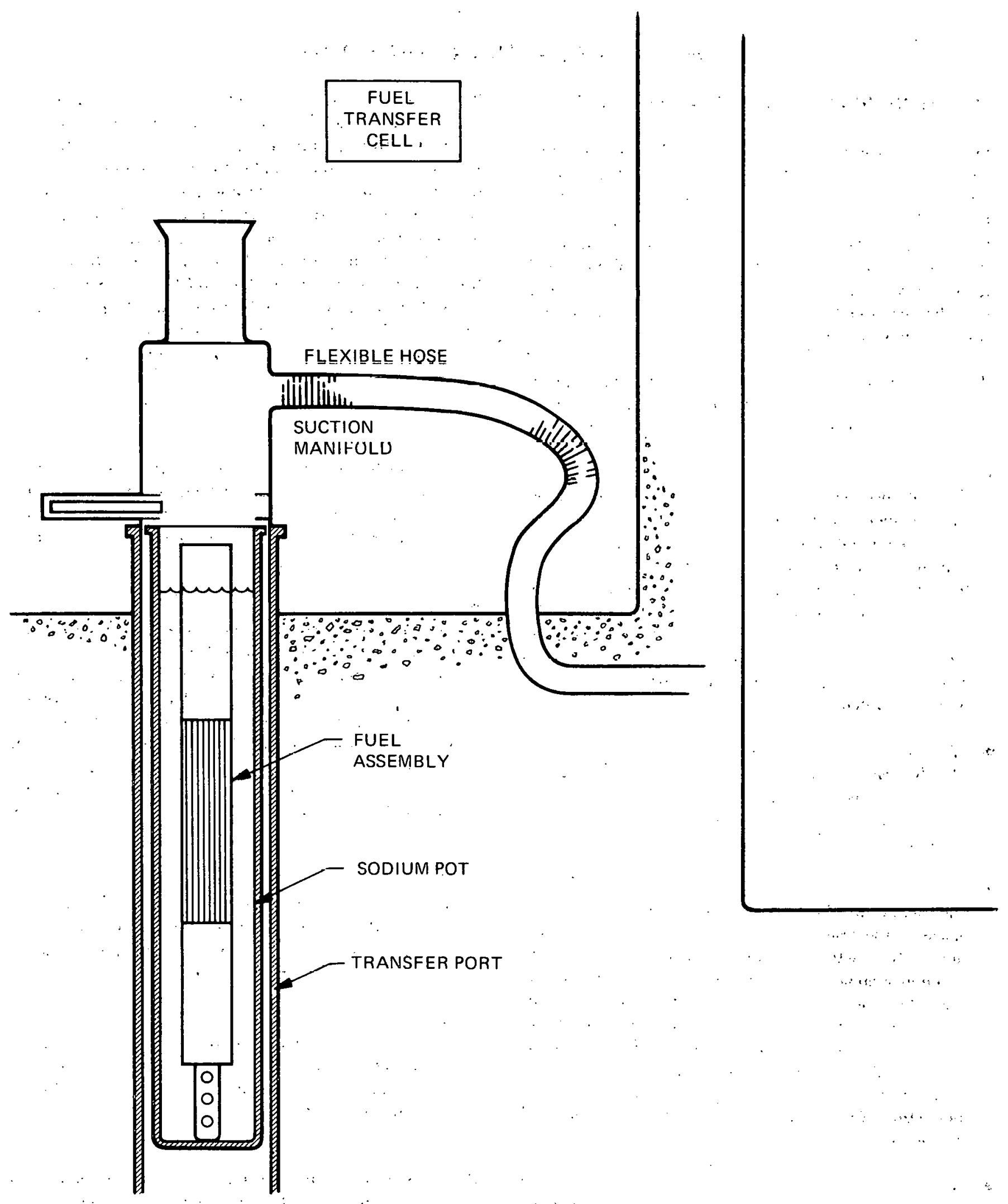

Figure 4.1. Entry of Fuel Assembly into Fuel Transfer Cell 


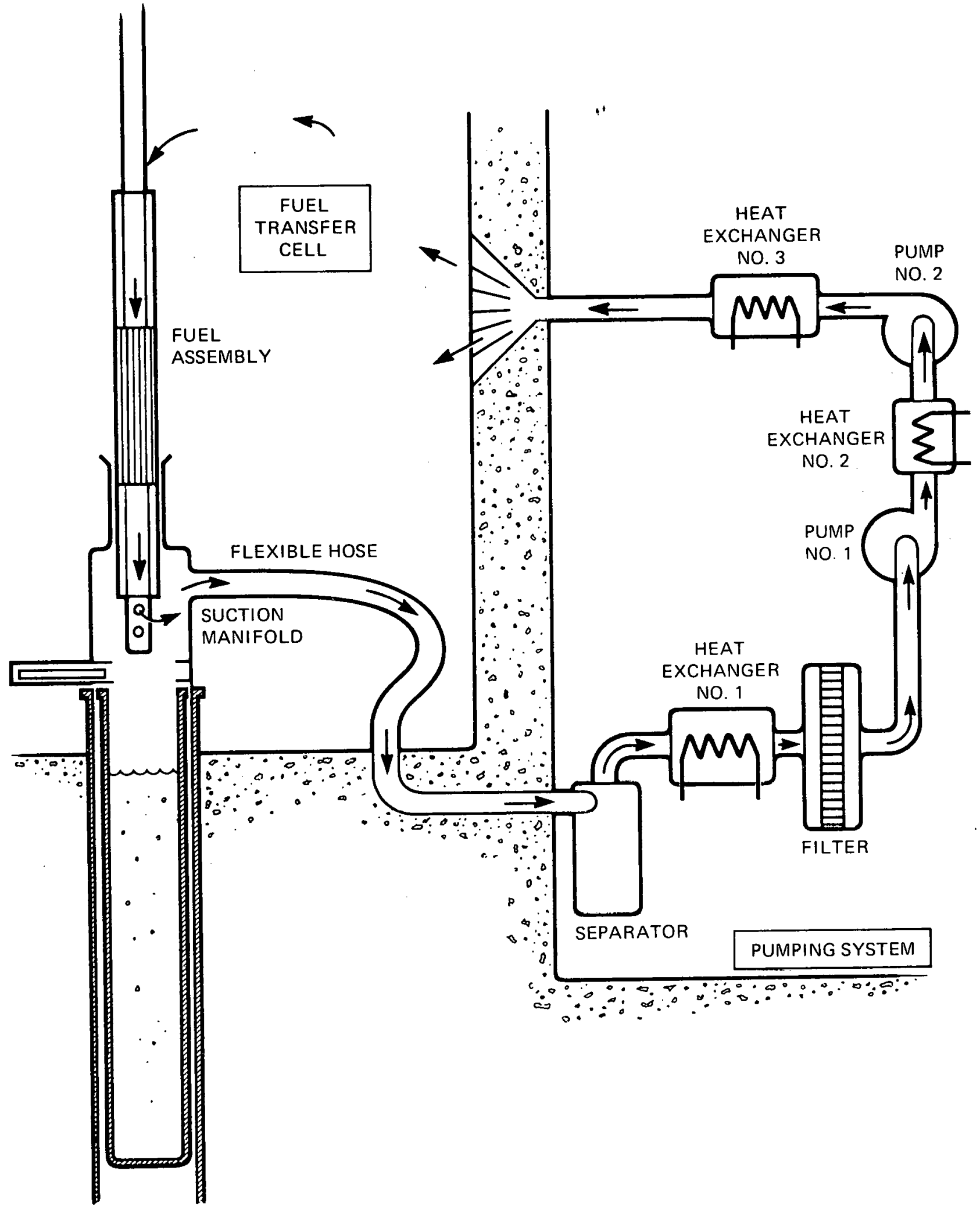

Figure 4-2. Transfer to Gas Cooling 
- (2)

The fuel assembly is in position where it is totally immersed in the sudium.

- (3)

The fuel assembly is raised to the position where its upper end enters the hexagonal seal region of the suction shroud. Rotation may be required to permit entering the seal. Since the fuel is still totally immersed in sodium, this operation may be done slowly.

- (4)

The heated region of the fuel has reached the sodium level. Subsequent steps must be carried out rapidly until gas cooling is established.

- (5)

The fuel assembly is at an intermediate position where the second spacer pad on the fuel assembly enters the seal region and the first spacer pad leaves.

- (6)

Gas flow is initiated in this position.

\subsection{DESCRIPTION OF OPEN LOOP FUEL TRANSFER}

The handling of instrumented fuel differs from handling of driver fuel mainly in the accommodation of the long handle and instrumentation leads. The difference is shown in Figure 4-5. When the instrumented assembly is brought into the transfer port in the sodium-filled pot, the instrumented extension will project vertically into the rell The suction manifold is made with a removable two-plese he xagonal seal insert which is installed after the handle of the fuel assembly has passed through the surtion manifold. This feature is necessary since the flange is larger than the hexagonal outer surface of the fuel assembly. The following descripiton refers to the seven sequence operations numbered in Figure 4-5.

\section{- (1)}

The fuel assembly and transfer pot is being inserted into the transfer port.

- (2) With the transfer pot in place, the suction manifold is installed over the top and clamped down.

- $(3,4)$

The two piece hexagonal seal is installed in the suction manifold.
- (5)

As with the driver fuel, the fuel assembly is raised into the suction manifold and suction gas cooling established.

- (6)

The fuel assembly is transferred to another station in the same manner as a driver fuel assembly. ..

- (7)

The downward removal of the transfer pot is shown after the fuel assembly has been removed.

\subsection{TRANSFER IN THE CELL}

The description in subsections 4.1 and 4.2 mainly covers the transfer of fuel assemblies out of the sodium and into the cell. Transfer between stations in the cell is illustrated in the cell layout ( $F$ igure $4-6$ ) and in the perspective picture of the cell (Figure 2-1). Although the cell layout is subject to rearrangement, the general principles would still apply.

The single 12-foot length of hose is adequate to provide transfer of a fuel assembly to most points in the fuel handling cell, as shown in the plan view of Figure 4-6. Moving a fuel assembly into the interim examination and disassembly cell requires that the luel assembly be first placed in a temporary storage station. 'This is shown in Figure 4-7. The storage station consists of a fixed flange to fit the suction manifold. Below the flange is a suction system connertion and a fitting into which the nose prece of a fuel assembly can be plugged. This differs trom the other floor storage positions in the location of the fittıng which is near floor level. Operation consists of attaching the suction mandold to the flange, starting the suction system of the hose transfer station, opening the gate valve on the suction manifold. and lowering the fuel assembly until its nose picce engages the suction fitting. At this point. the suction to the hose can be slupped and the hose relocated to connect to another fixed suction port. After starting up the hose suction again, the fuel can be lifted and the gate valvr again closed. Suction at the hose transfer station is then stopped and the transfer operation continued.

Other floor storage positions are similar to the hose transfer station except that they are sufficiently deep to permit the fuel assembly to be lowered to a greater depth. As shown in sequences 6,7 , and 8 of Figure 4-3, the assembly is not stored completely below the floor level, because it is necessary to make connection with the nose piece of the fuel assembly before the hexagonal surface leaves the seal region in the suction manifold. An alternate would be to provide an insert in the floor suction cavity that has a hexagonal 
GEAP-10058

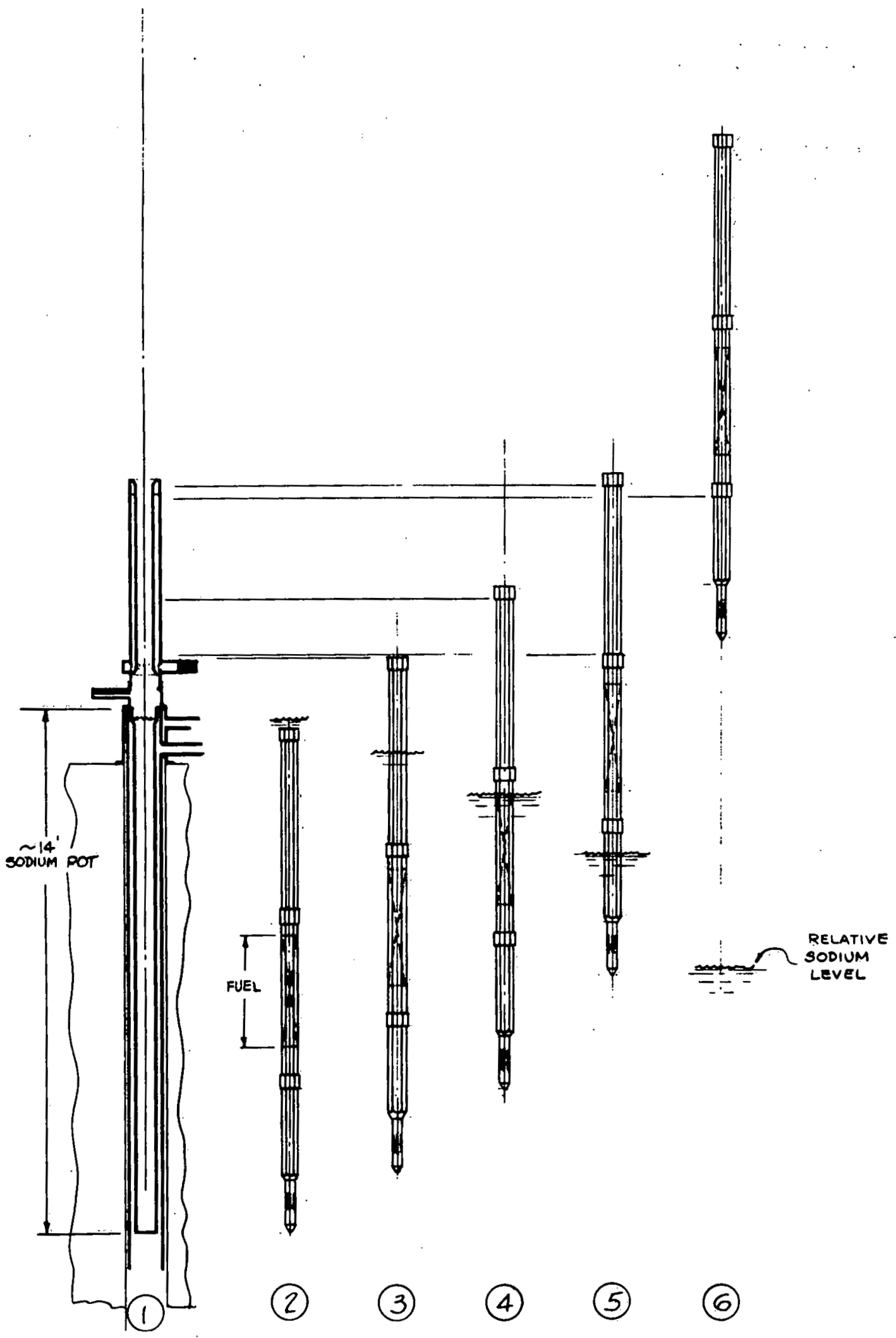

Figure 4-4. Driver Fuel Sodium-Gas Interface 
sealing surface. This would permit the fuel assembly to be lowered below the floor level without interrupting gas flow.

Other stations must be equipped with a similar means of applying suction to these lower ends, unless their function can be served with the suction manifold and hose connected. The cooling manifold will be left in place for the neutron radiography and gamma scan examinations, since these operations will not have special cooling equipment. The use of removable inserts permits the individual stations to be adapted to a variety of nose piece designs. 


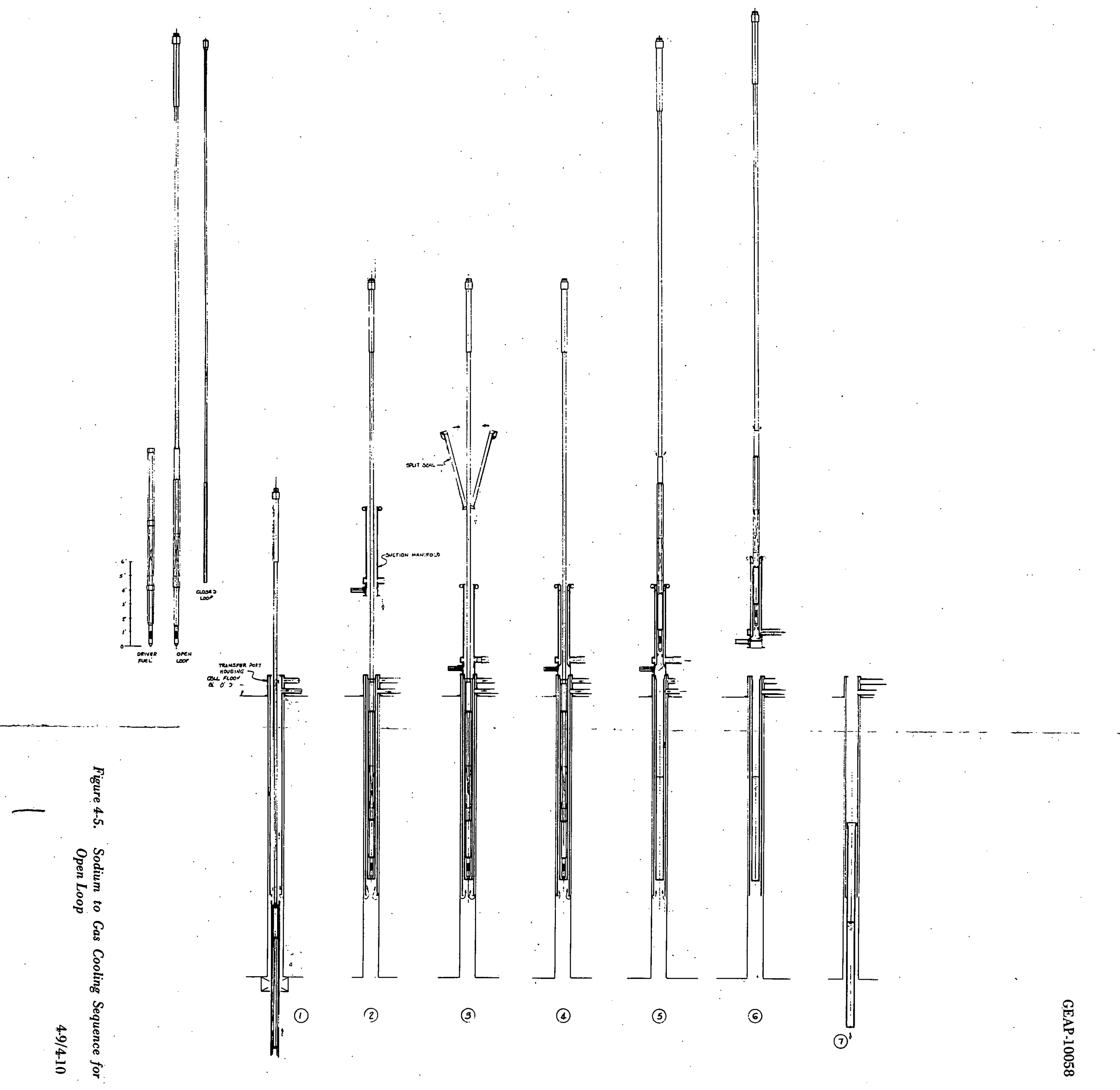




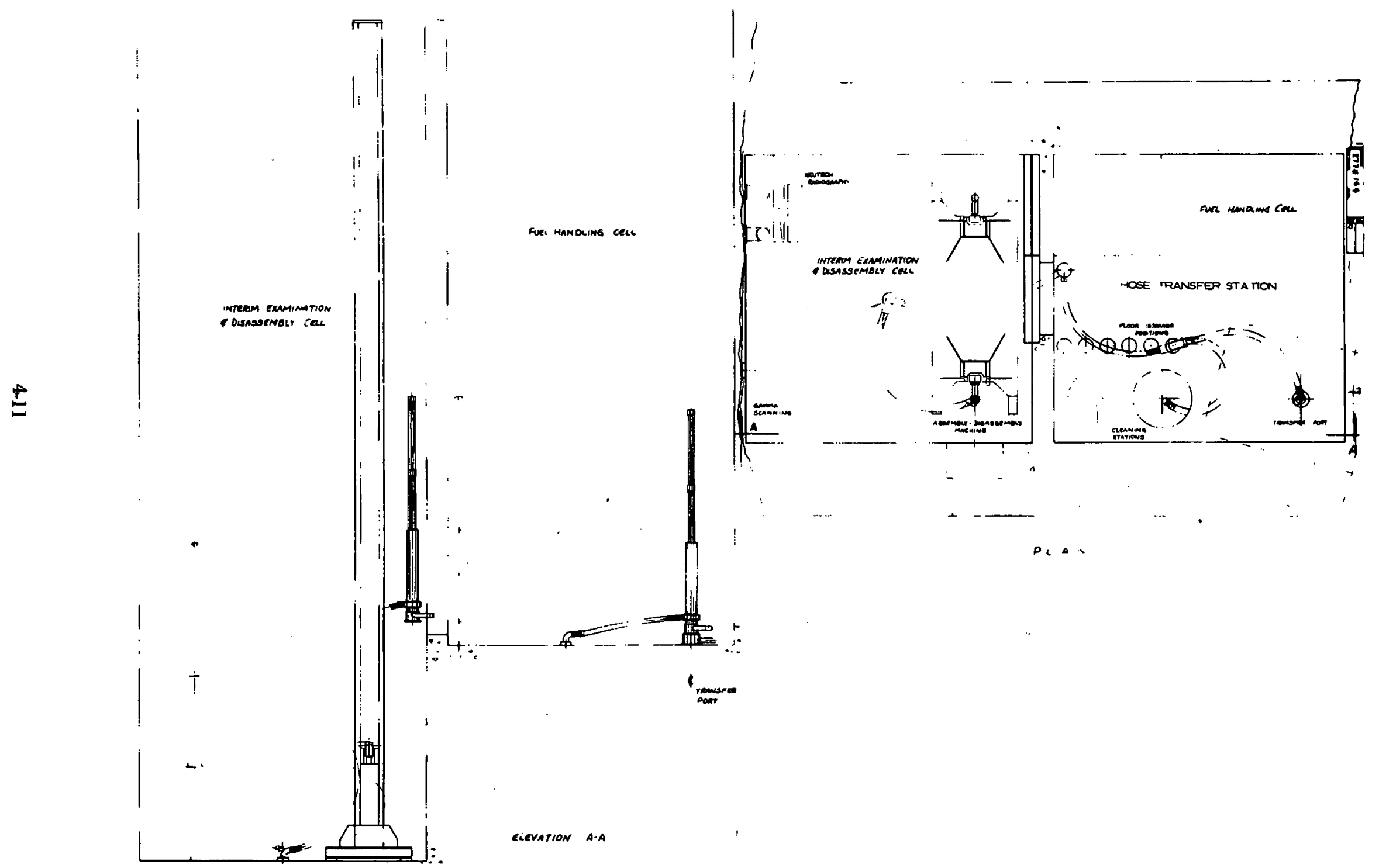

Figure 4-6. Driver Fuel Axial Gas Cooling Transfer Sequence 


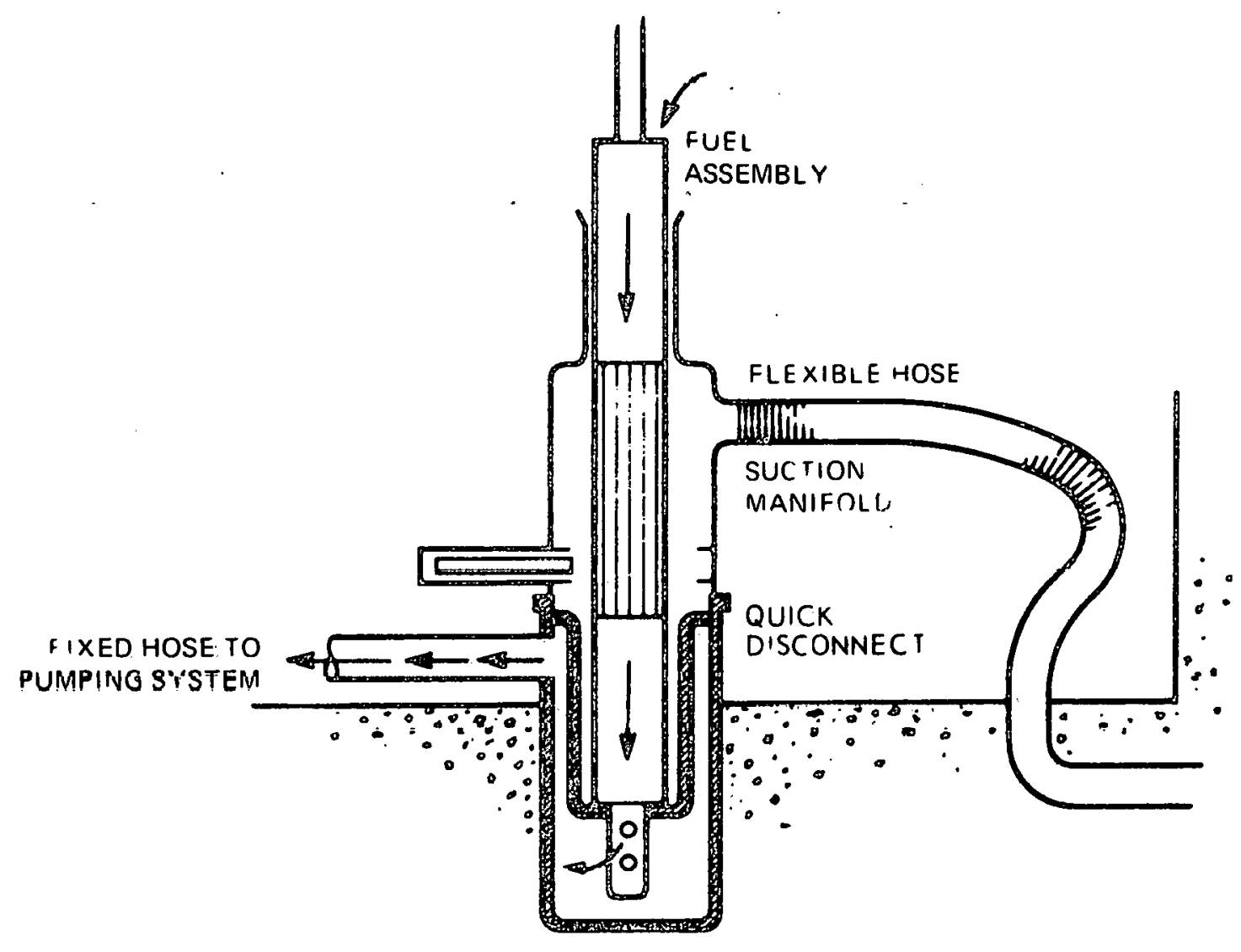

Figure 4-7. 7 7ompurarv Gas Cooled Fuel Itorage 


\section{Section 5.0 MAINTENANCE PRINCIPLES}

Maintenance of the gas cooling equipment is related to three general areas:

$$
\therefore \therefore
$$

- Maintenance of mechanical equipment to assure proper functioning.

- Controlling the spread of sodium and radioactive contamination in the cell. This includes maintaining cleanliness of the lower end of the suction manifold and of the suction hose.

- Cleanup of equipment whose function is compromised by the accumulation of sodium in the suction hose or the suction manifold. This would be of particular concern in the event of a failure to lift a fuel assembly completely out of the liquid sodium before starting the suction system.
Provisions should be made for filter maintenance and replacement requirements.

Periodic checks should be made of the flow system for detection of flow blockage or restriction resulting from for eign objects, sodium accumulation, or component malfunction.

All maintenance of in-cell equipment will be by remote manipulator operation, except where decontamination and contact maintenance is permissible or equipment replacement is required.

Decontamination and cleaning of equipment will in most cases require removal from the cell by conventional methods. 


\section{APPENDIX A}

\section{ALTERNATE COOLING METHODS}

Several other methods of axial gas cooling have been considered:

\section{A.1 PRESSURE COOLING}

In this method, the argon is supplied to the fuel assembly at a pressure greater than atmospheric and then discharged into the cell. In comparison with suction cooling, this method of cooling requires less pumping power and presents less of a limitation on the maximum amount of heat that can be accommodated. Its major drawbacks are the difficulty in avoiding the blowing of sudiun vapor and other contaminants into the cell and the necessity for having the cell argon cooling system accommodate the heat introduced by the hot discharge gas. Furthermore, tests have shown that this mode gives serious hot spots during the transition from axial to transverse flow as the duct is removed. Because of these problems, the pressure cooling system was not further studied.

\section{A.2 DOWNWARD SUCTION COOLING ATTACHED TO THE LOWER END OF THE FUEL ASSEMBLY}

This method differs from the reference design in the fuel assembly not being drawn up through the suction manifold but plugged into the top of the manifold. The method of attachment would consist of first raising the fuel assembly and then lowering it into the suction manifold.

The three most serious drawbacks of such an arrangement follow:

- There is poorer control of sodium dripping when the fuel assembly is raised out of the transfer pot.

- A temporary period without cooling is necessary for the transfer, thus lowering the allowable temperature while cooling is in operation.

- There is additional hazard of not completing the transfer before severe overheating occurs.

\section{A.3 UPWARD SUCTION WITH THE SUCTION MANIFOLD ATTACHED TO THE UPPER END OF THE FUEL ASSEMBI,Y}

At the beginning of this study this method was tentatively selected as a reference. Its principal advantage over the final reference design is that it eliminates the sliding seal to the hexagonal outside of the fuel assembly. The sequence of operations is shown in Figure A-1 for a driver fuel assembly. Refer to the sequence numbers on that drawing for the following brief description of the transfer:

- (le)

The cooling manifold is brought in and attached to the top of the fuel assembly.

- (2e)

A circular sliding seal is engaged to the cylindrical outer surface of the cooling manifold.

- (3e)

The fuel assembly is raised out of the sodium by lifting the cooling manifold. Couling flow is established downward through the fuel assembly by a separate suction cooling system built into the transfer pot.

- (4e)

The cooling flow is reversed by suction on the flexible hose attached to the upper end of the cooling manifold. To permit this reversal, a valve is opened to permit cell argun to pass to the bottom of the fuel assembly.

- (5e)

The circular sliding seal is opened permitting cell gas to reach the fucl asscmbly dircetly

- (6e)

The fuel assembly is raised and transported to another station. The other station would be provided with a similar system for down suction on the fuel assembly.

This method of fuel transfer was rejected because of the following disadvantages:

- It requires a considerable amount of vertical motion of the flexible hose.

- It requires extra valving as well as a careful sequencing of these valves in order to reverse the coolant flow.

- It is more difficult to accommodate instrumented fuel assemblies, because the cooling manifold must be split over its entire length in order to be installed. 


\section{A.4 UPWARD SUCTION DURING THE ENTIRE TRANSFER}

This method differs from the previous one (subsection A.3) in that no provision is made for downward suction at the station where the fuel assembly is removed from the sodium pot. A suction manifold is attached to the upper end of the fuel assembly. After it is raised out of the sodium, the upward flow is started. Although this system requires less equipment than the previous one. it would be considerably less effective in removing liquid sodium from the fuel assembly and would cause considerably more sodium to be carried into the flexible hose under normal conditions. 
$\frac{p}{b}$

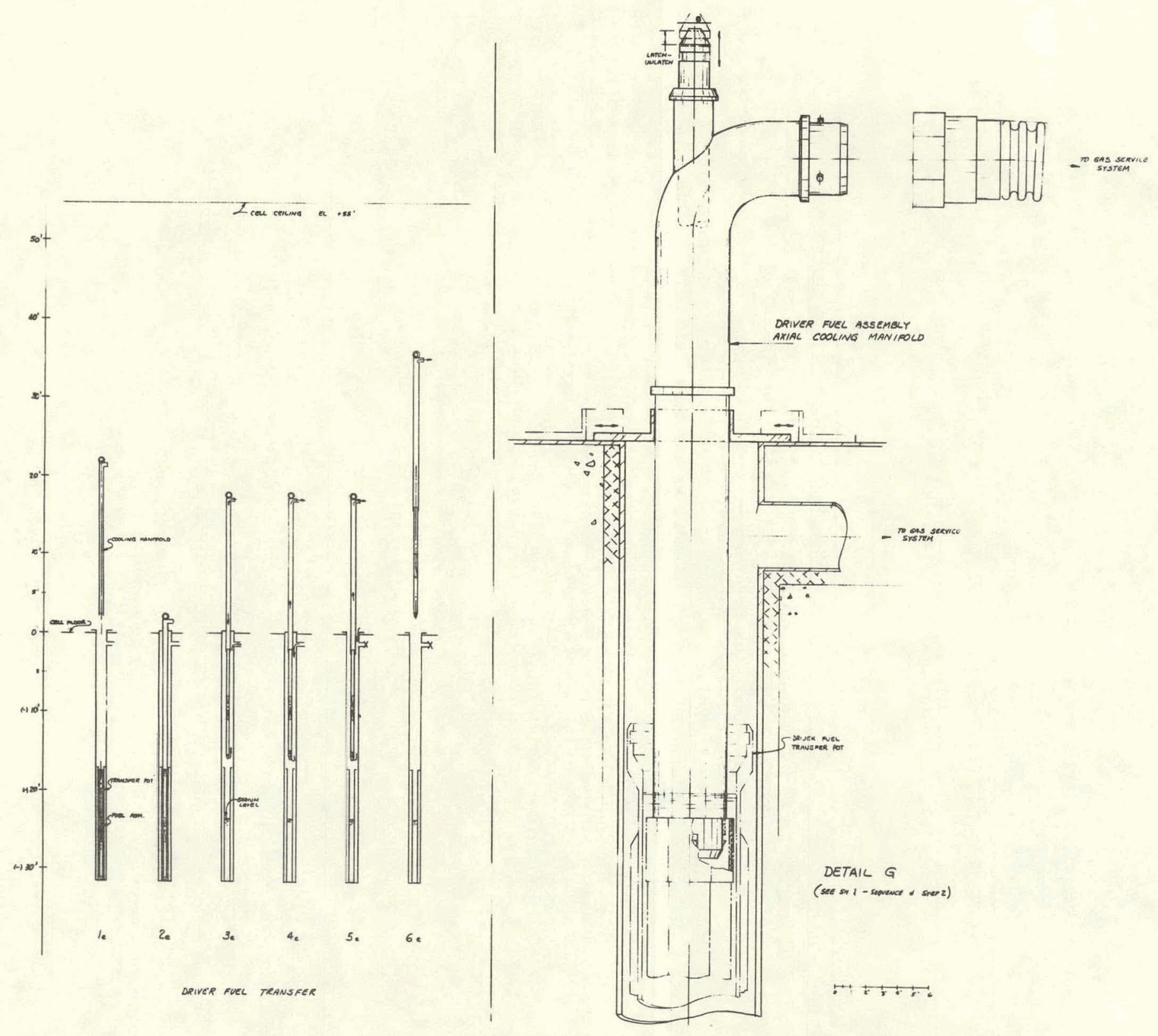




\section{APPENDIX B}

\section{SUBSTITUTES FOR SUCTION HOSE}

The description of the transfer operation includes a flexible metal hose to connect the suction manifold to the pumping system. The use of a flexible hose presents some problems in transferring into the fuel examination cell because of the weight of the hose and the difference in floor level (see Figure 4-6). Extreme care must be taken in making a transfer into the fuel examination cell to prevent the weight of the hose from exerting an excessive side force on the fuel assembly as it passes into the region of the lower floor. Three alternate arrangements should be considered in order to minimize this problem. It should be noted that the following arrangements are compatible with the reference hose design and could be used for particular parts of the transfer if desired rather than for all of the operations.

- Figure B-1 shows an articulated suction tube to replace the hose. This consists of two sections of pipe connected by flexible joints.

The first section of tube is cantilevered from a fixed pivot, permitting it to swing in a horizontal plane. The diameter of the tube ( 6 in.) is based more upon the requirement of rigidity and strength than flow capacity. Its length is dictated by the requirements for range of coverage within the cell.
The second section of tube (4-in. diam) is pivoted onto the end of the first tube, with its weight taken both by the suction manifold and the end of the first tube. Flexible joints are incorporated in this second tube to permit a limited amount of vertical motion of the suction manifold.

- A variation of the above arrangement consists of replacing the second section of tube with a flexible hose. This offers some advantages in permitting more flexibility to reach remote points in the cell, while permitting the use of a shorter hose length than in the reference design.

- A retractable hose can be withdrawn as required from a fixed feed-through tube. This arrangement has been used successfully in the Fuel Cycle Facility of the EBR-II.*

* Ferguson, K. R., Simon, J. P., White, J. R., "Cooling Grapple For Handling Radioactive Sources," American Nuclear Society proceedings of the 13th Conference on Remote Systems Technology, 1965. 
GEAP-10058
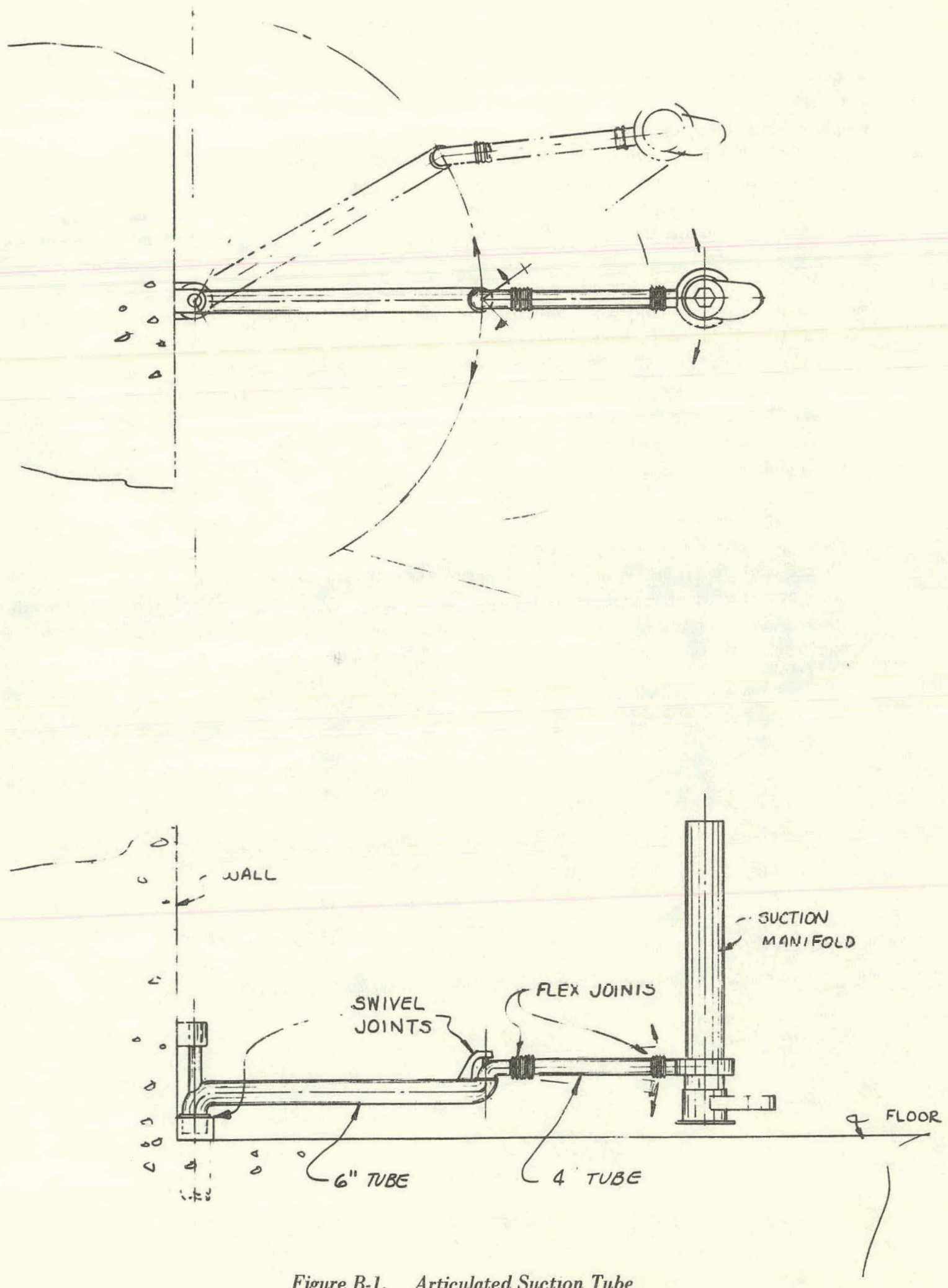

Figure B-1. Articulated Suction Tube 


\section{APPENDIX C}

\section{PUMPING SYSTEM ANALYSIS}

The amount of power required to pump argon back to the pressure of the cell was calculated under isentropic conditions from the following equation:

$$
\text { horsepower }=N(k / k-1)(p v / 229.2)\left(R^{(k-1) / N k}-1\right)
$$

$$
\text { where: }
$$

$$
\begin{array}{ll}
\mathrm{N} & =\text { number of stages } \\
\mathrm{k} & =\text { specific heat ratio }(=1.667 \text { for argon) } \\
\mathrm{p} & =\text { supply pressure }(\mathrm{psia}) \\
\mathrm{v} & =\text { volume, flow rate at inlet }\left(\mathrm{ft}^{3} / \mathrm{min}\right) \\
\mathrm{R} & =\text { overall compression ratio }
\end{array}
$$

The above expression assumes equal pressure ratios in multi-stage pumping and is exact only if the fluid behaves as a perfect gas.

The results of the calculation are shown in Figure $C-1$ for both one and two stages of pumping. A nominal inlet flow through the subassembly of $240 \mathrm{ft}^{3} / \mathrm{min}$ at a temperaturc of $100^{\circ} \mathrm{F}$ and various inlet pressures was assumed for the analysis reported in this appendix. ${ }^{*}$ Intercooling to $100^{\circ} \mathrm{F}$ was assumed with two stages. Outlet pressure was assumed to be 14.7 psia. In terms of pumping power. very little incentive is shown for intercooling between two stages. Fig- ure C-l also indicates the outlet temperatures of the pump for one or two stages, where $\mathrm{T}_{\text {out }} / \mathrm{T}_{\mathrm{in}}=\mathrm{R}^{(\mathrm{k}-\mathrm{l}) / \mathrm{Nk}}$. The principal reason for recommending two stages is to permit independent drives on each stage, thus assuring that flow will continue if one unit fails. The purpose of the intercooler between stages is to decrease the operating temperature of the second pump.

The results of decreasing pump efficiencies from 1.0 (isentropic) to 0.6 are shown in Figure C-2 for the case of two stage pumping with intercooling. The power input must be increased, and this additional energy shows up in an increased pump outlet temperature. Another effect which causes additional power requirements is leakage flow: from the cell into the pumping system at the suction manifold. Leakage rates of up to $50 \%$ of the required assembly, cooling flow are shown in Figure C-3. Note that this leakage docs not affect the outlet temperatures of the pumps. Thus, the temperatures shown in Figure C-2 apply regardless of the amount of leakage.

The temperature-entropy plot of a typical pumping system cycle for argon is shown in Figure C-4. This eycle is very similar to the final design conditions of the reference system.

\footnotetext{
* Table 1-1 shows the final reference condition for the pumping system to be $252 \mathrm{ft}^{3} / \mathrm{min}$ at $100^{\circ} \mathrm{F}$ and 14.7 psia.
} 


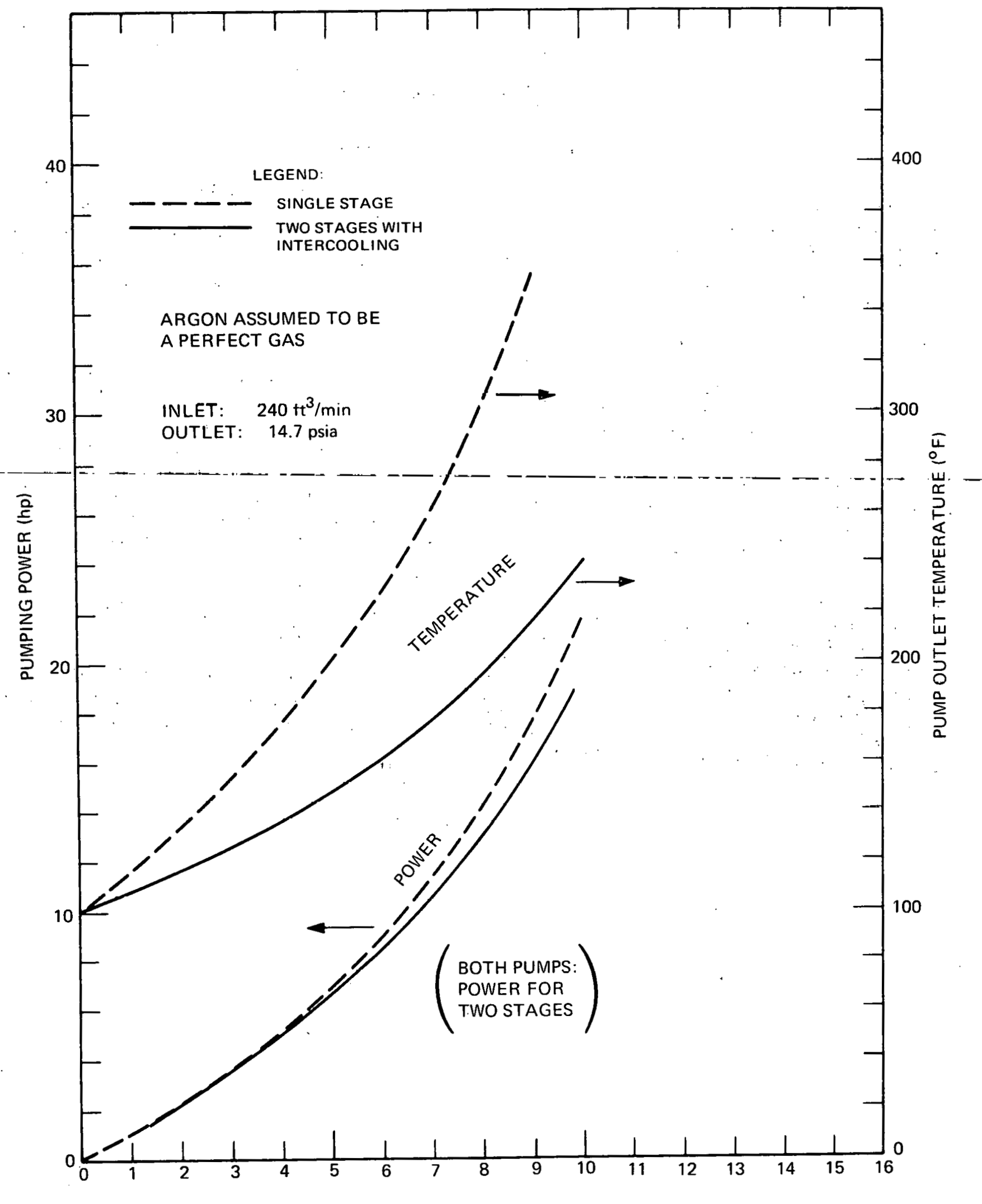

TOTAL NET PRESSURE RISE (psi)

Figure C-1. Isentropic Pumping Power and Pump Outlet Temperature Versus Pressure Rise 


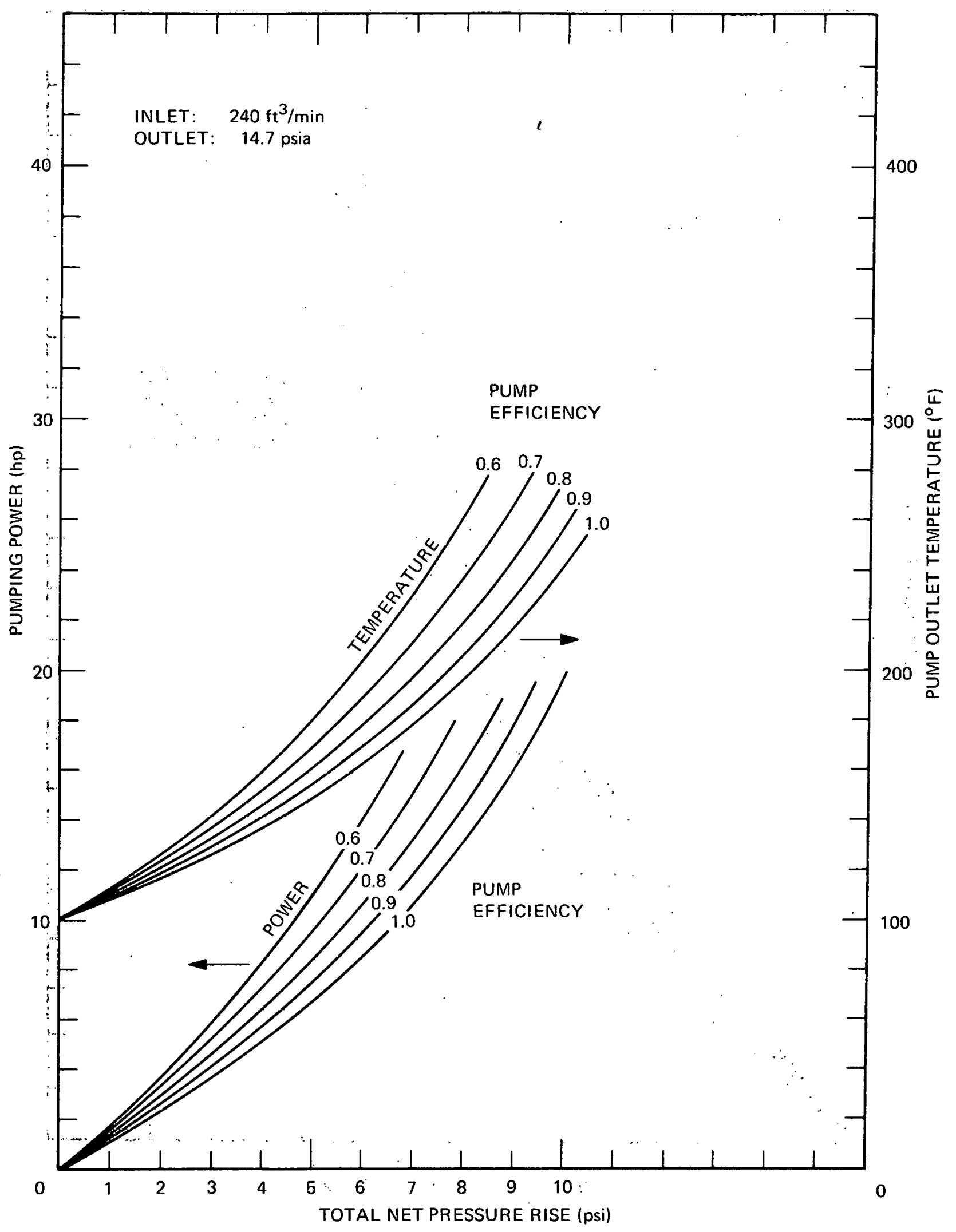

Figure C-2. Two Stage Pumping Power and Pump Outlet Temperature Versus Pressure Rise and Pump Efficiency 


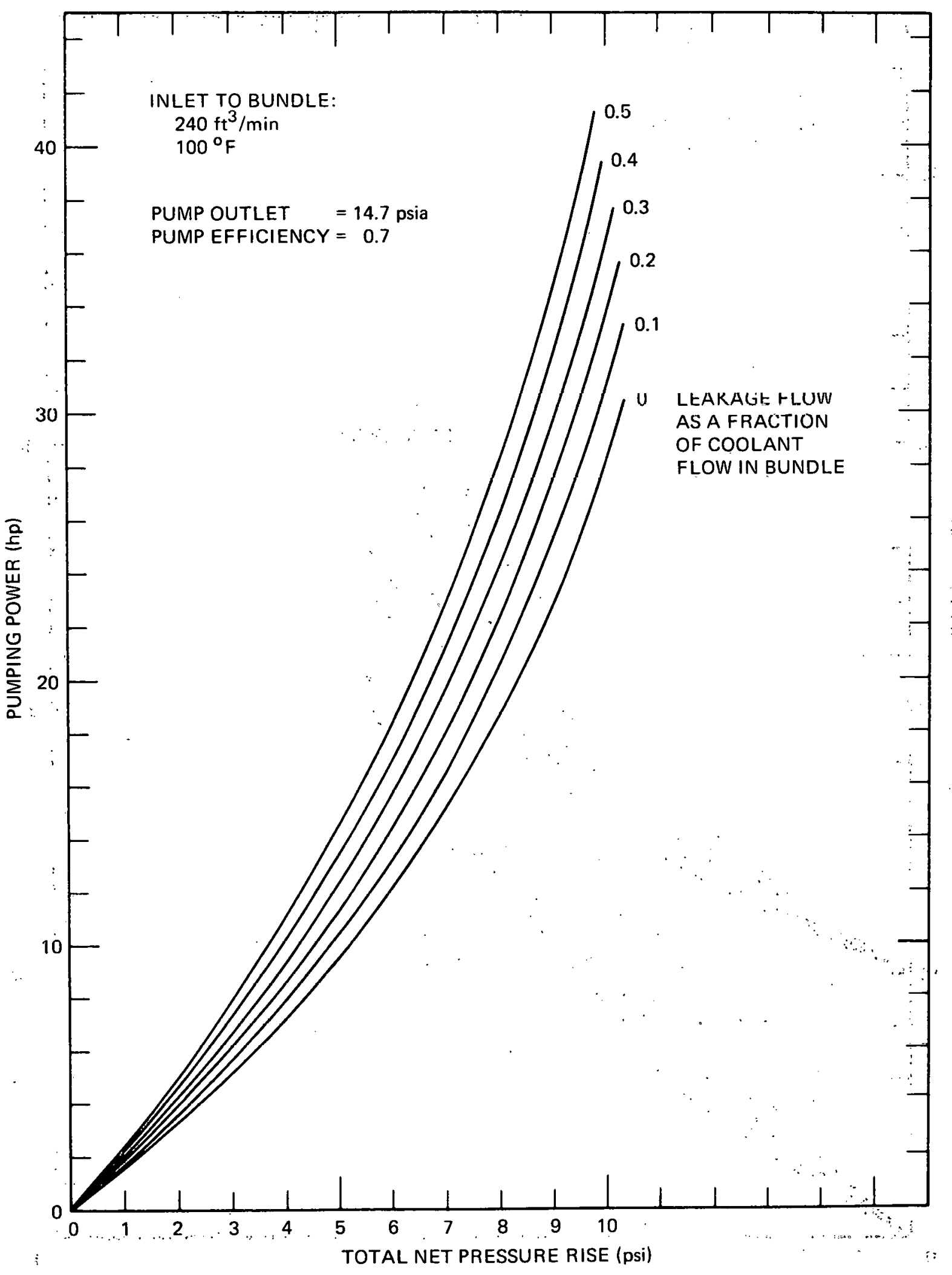

Figure C-3.. : Two Stage Pumping Power Versus Pressure Rise and.Leakage Flow 


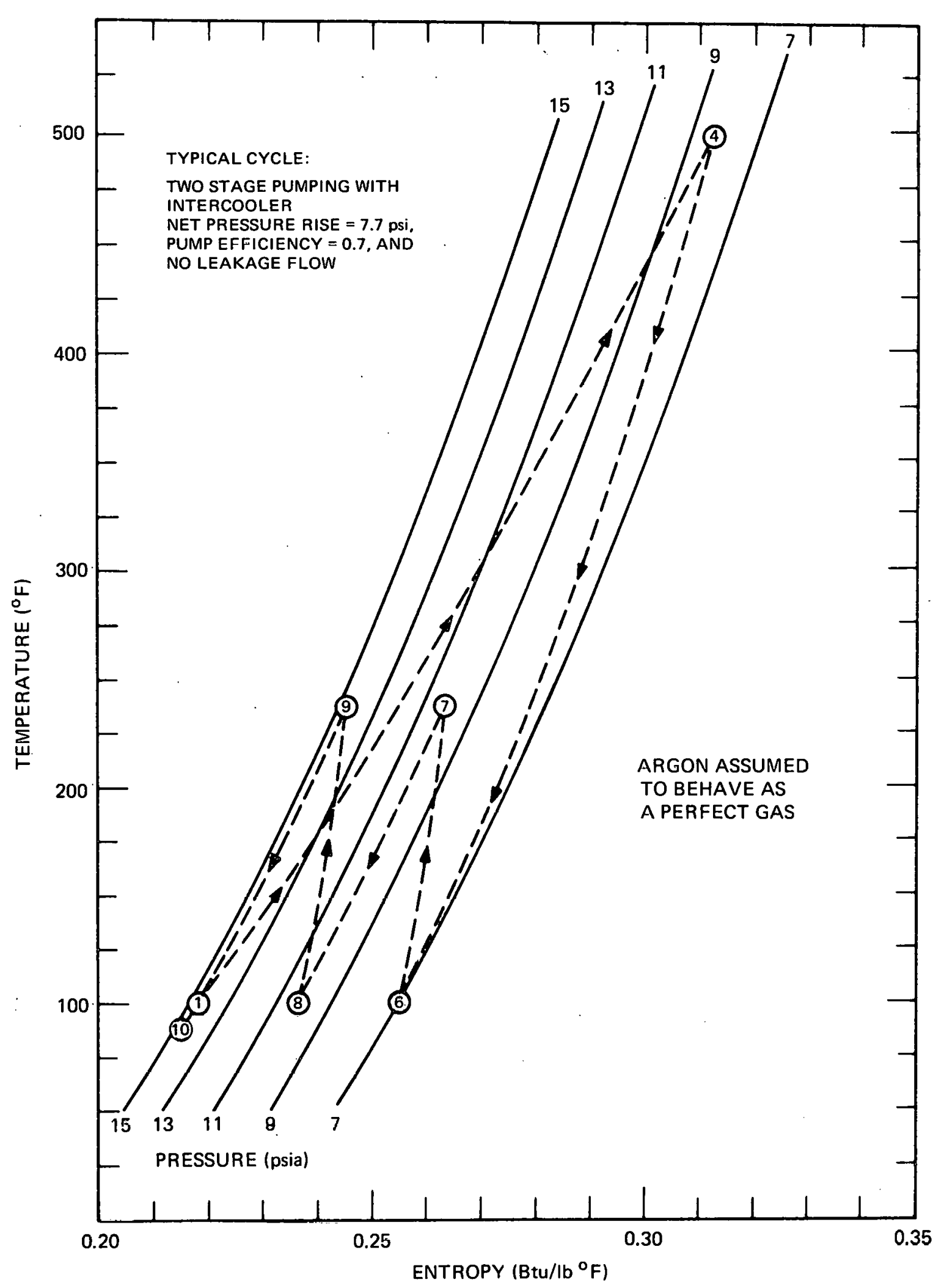

Figure C-4. Temperature Versus Entropy 


\section{APPENDIX D \\ HEAT TRANSFER AND FLOW CHARACTERISTICS}

\section{D.I INTRODUCTION}

The object of the heat transfer and fluid flow analysis is to provide design information on the relationship between temperatures, pressure drop, and mass flow rate. This was accomplished by the development and use of the computer code, MACH. The code MACH performs a thermalhydraulic analysis of a fuel rod assembly. It has the following capabilities:

- compressible flow

- variable properties

- nonuniform heat generation

- heated and nonheated sections

- laminar and turbulent flow

MACH is coded in time-sharing FORTRAN for the GE 635 computer and is described in Appendix $\mathrm{E}$.

For the present study the following design correlations and reference conditions were used for the fuel assembly cross section* shown in Figure D-1. This geometry differs from that presented by Dickinson ${ }^{* *}$, and a more detailed analysis was used.

\section{Power distribution}

chopped cosine with peak/average $=1.2$

Heat transfer coefficient

turbulent flow $\mathrm{Nu}=0.027 \mathrm{Re}^{\mathrm{n} .8} \mathrm{Pr}^{0.3}$

laminar flow $\mathrm{Nu}=4.364$

Friction factor

turbulent flow $f=0.079 / \mathrm{Re}^{0.25 * * *}$

laminar flow $f=16 / \mathrm{Re}$

* Walker, R. C., ed., "FFTF Reference Concept Summary Description," January 1969, (BNWL-955).

** Dickinson, D. R., "Gas Cooling of FFTF Fuel During Examination and Disassembly Preliminary Feasibility Study,"July 1967, (BNWL-524).

*** Sangster, W. A., "Calculation of Rod Bundle Pressure Loss," 1968, (ASME 68-WA/HT-35).

\begin{tabular}{|c|c|}
\hline inlet temperature & $100^{\circ} \mathrm{F}$ \\
\hline inlet pressure (suction) & $14.6 \mathrm{lb}_{\mathrm{f}} / \mathrm{in}^{2}$ \\
\hline exit pressure (blowing) & $14.6 \mathrm{lb}_{\mathrm{f}} / \mathrm{in}^{2}$ \\
\hline wetted length & $7.75 \mathrm{ft}(93 \mathrm{in})$. \\
\hline heated length & $3.0 \mathrm{ft}$ (36 in.) \\
\hline \multicolumn{2}{|c|}{ length to beginning of heated length $4.02 \mathrm{ft}$ (48.25 in. } \\
\hline equivalent diameter & $0.01305 \mathrm{ft}$ \\
\hline flow area & $0.0467 \mathrm{ft}^{2}$ \\
\hline heated area & $39.199 \mathrm{ft}^{2}$ \\
\hline Reynolds number (laminar flow) & $<2300$ \\
\hline Reynolds number (turbulent flow) & $>2300$ \\
\hline
\end{tabular}

For the down flow cases the heated section began at an $\mathrm{X} / \mathrm{L}$ of 0.519 while for the up flow case the heated section started at an $\mathrm{X} / \mathrm{L}$, of 0.094 .

Three cooling schemes were investigated:

- downward suction

- downward blowing

- upward suction

\section{D.2 RESULTS}

\section{D.2.1 DOWNWARD SUCTION}

The results between suction pressure drop, heat generation, and mass flow rate are presented in Figure D-2 as a function of the maximum wall temperature and in Figure D-3 as a function of the outlet coolant temperature. For the limiting conditions of $20 \mathrm{~kW}$ and $600^{\circ} \mathrm{F}$ maximum allowable wall temperature, the pressure loss is $2.1 \mathrm{psi}$. This $\Delta \mathrm{p}$ is only for the rodded length of the fuel assembly and does not include entrance and exit losses or losses in the unrodded sections. The flow rate for maximum wall temperature is 0.35 $\mathrm{lb}_{\mathrm{m}} /$ sec. The axial variation of temperatures for a more conservative condition of $0.5 \mathrm{lb}_{\mathrm{m}} / \mathrm{sec}$ is given in Figure D-4. The peak wall temperature of $446^{\circ} \mathrm{F}$ occurs near the end of the active core. For a given pressure loss, increasing the power reduces the flow rate through the assembly. This 


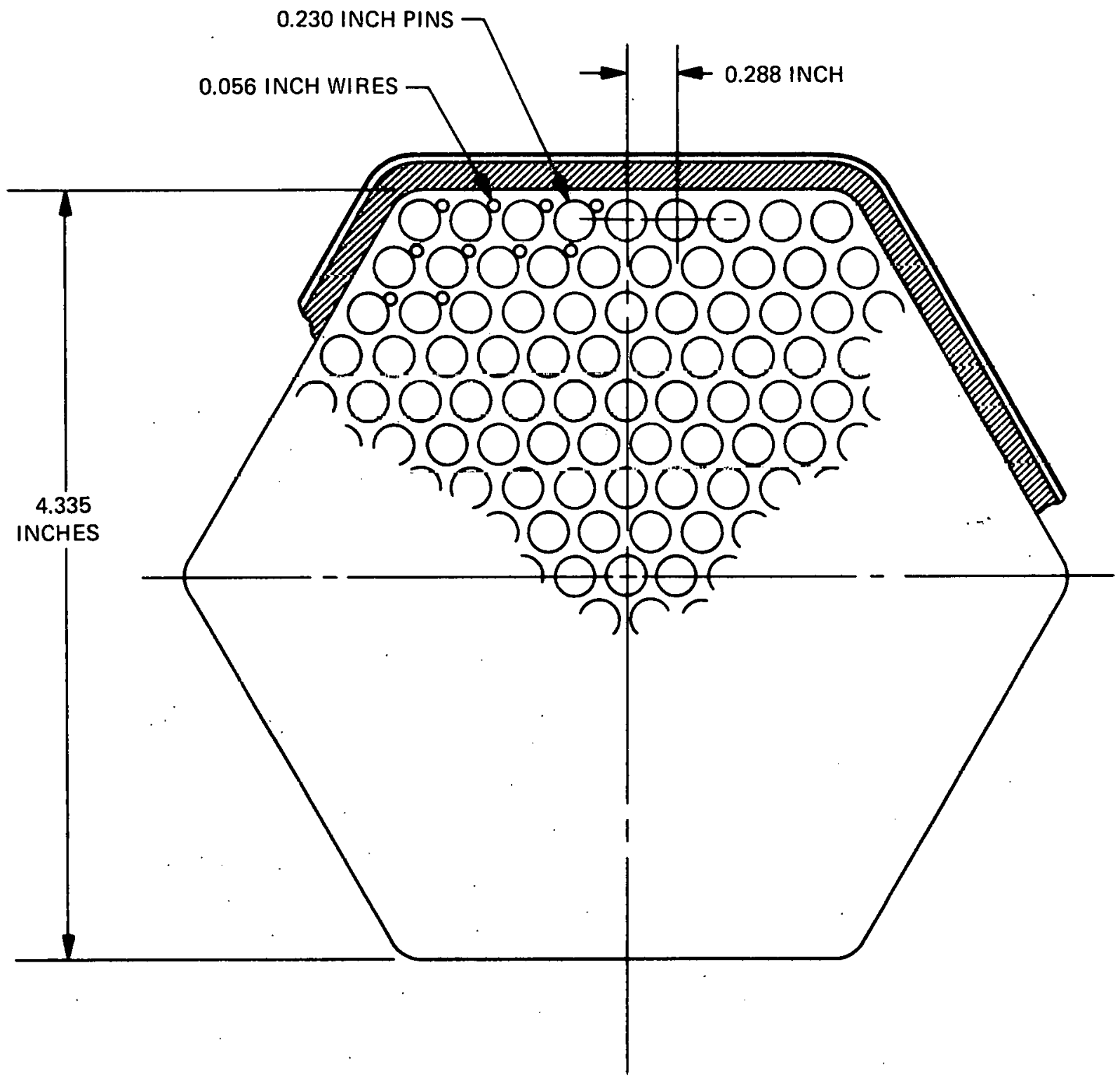

Figure D-1. 217 Pin Driver Fuel Assembly 
GEAP-1.0058

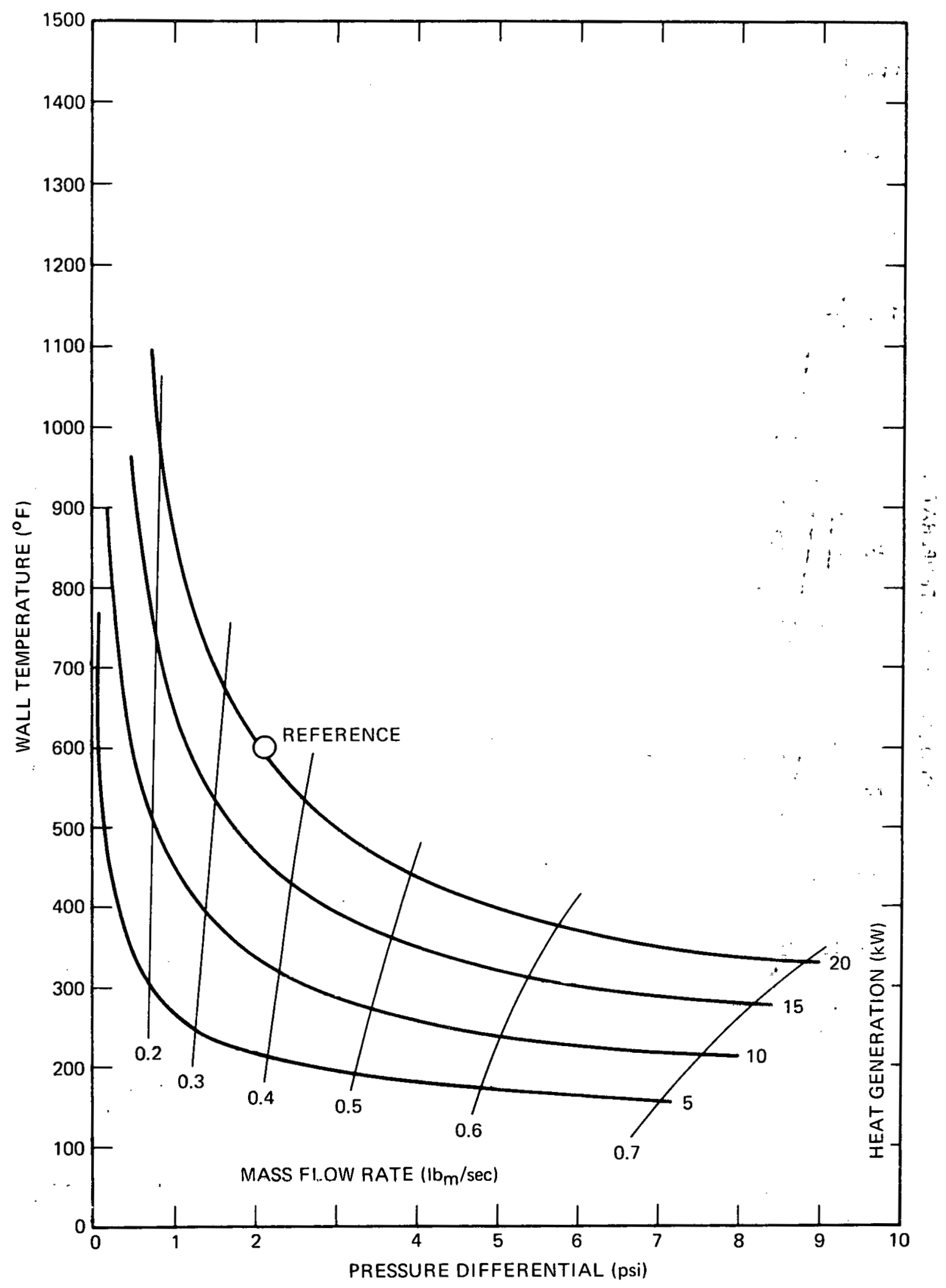

Figure D-2. Wall Temperature as a Function of Pressure Drop for Downward Suction 
(iLAP-10058

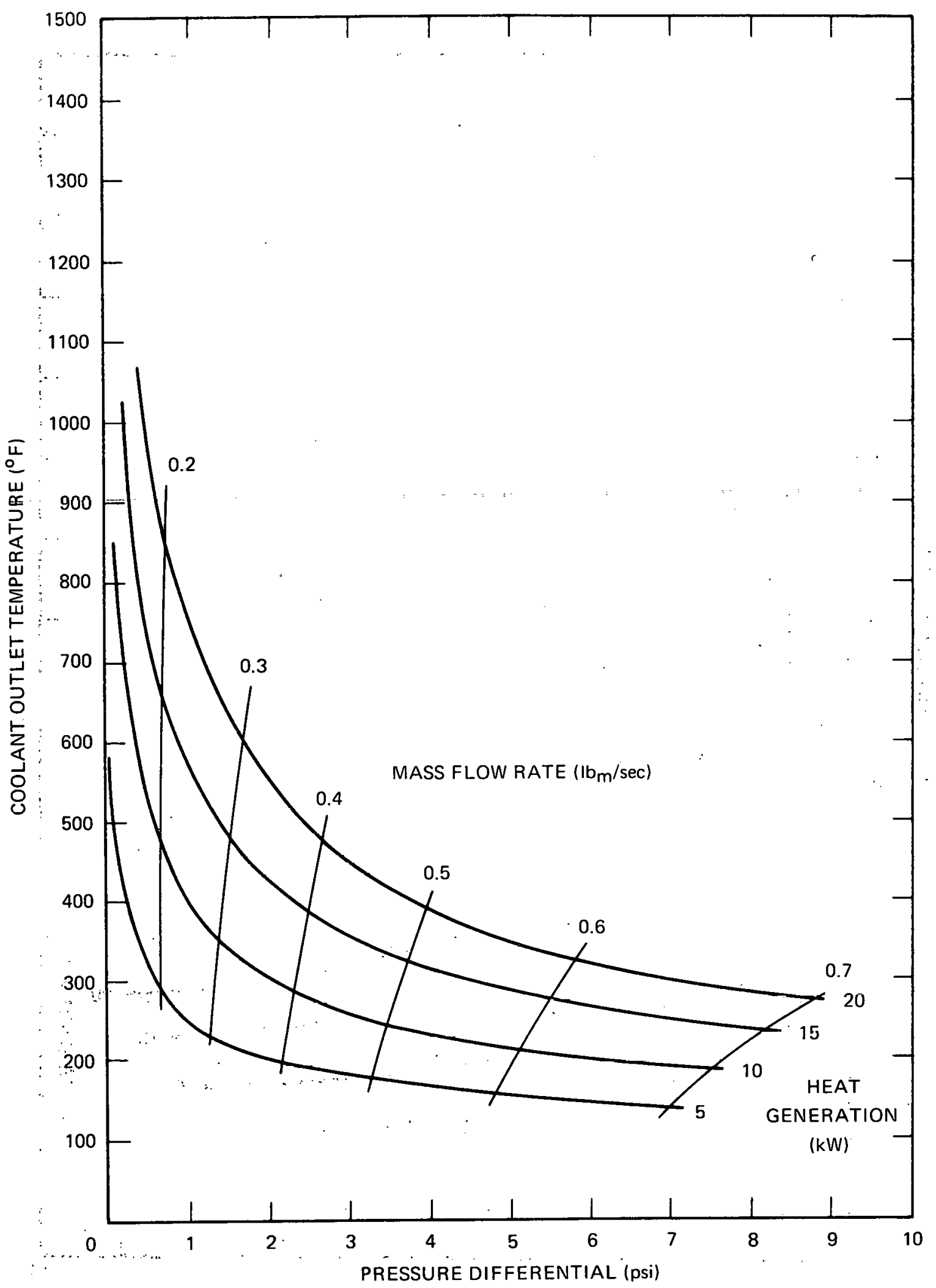

Figure D-3. Coolant Outlet Temperature as a Function of Pressure Loss for Downward Suction 


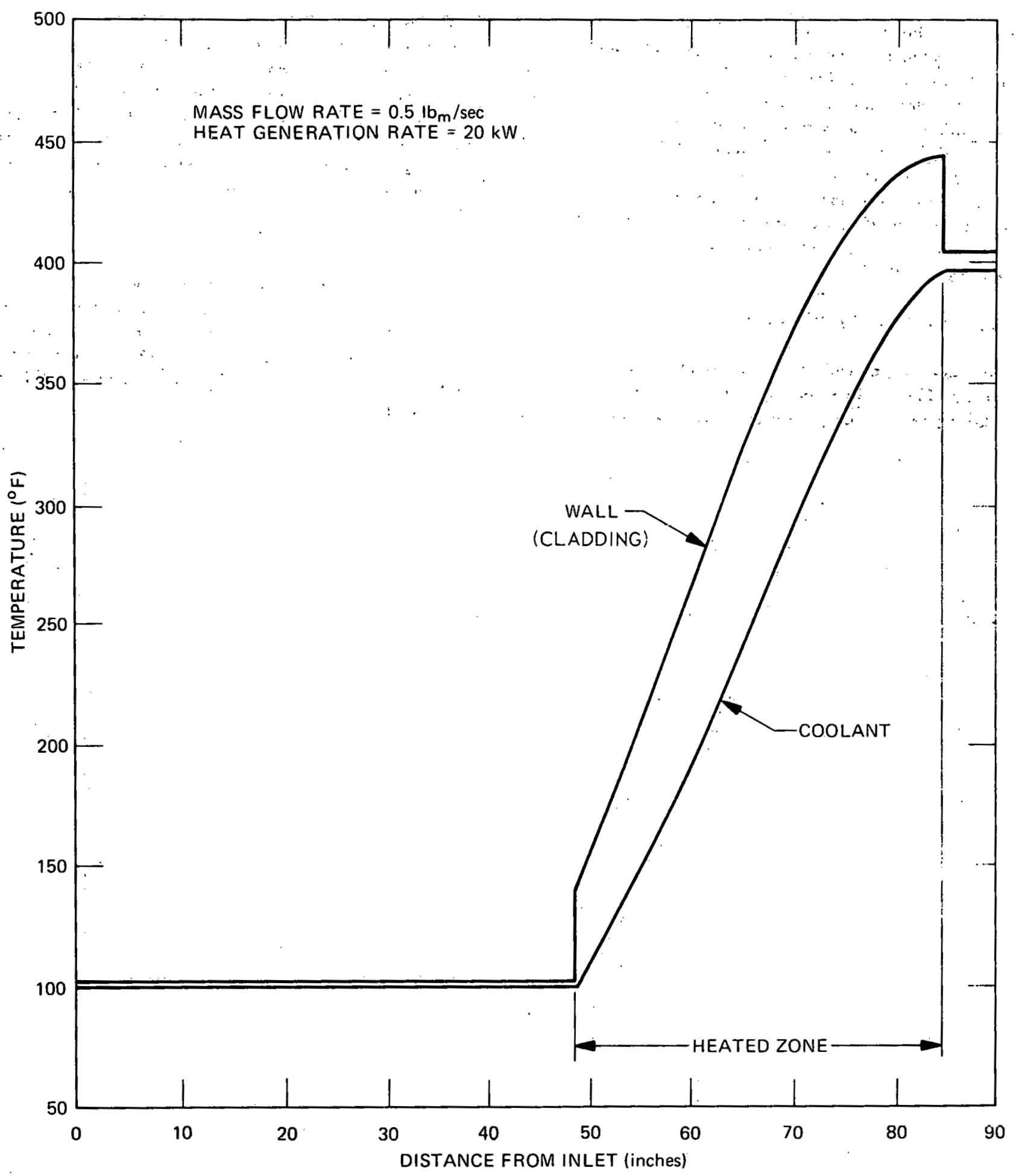

Figure DA. Coolant and Wall Temperatures as a Function of Axial Position for Downward Flow 
rline is slown in Figure 1).5. It high flow rates, the HAlll numbrer at thr. "xit approaches unity and choking results. as shown in Firure 1).6. For the $20 \mathrm{~kW}$ reference case the maximum tow rate is $0.74 \mathrm{lb}_{\mathrm{m}} / \mathrm{sec}$. The compressibility reflect at higher mass flon rates can be seen in ligurs 1).7 which show: the deviation of the stagnation and thr gas limperatures. It low flow rates, the flow characteristic become laminar in the heated section. This results in significantly higher wall temperatures. The reference casc exhibited laminar transition for flow rates less than $0.3 \mathrm{lb} / \mathrm{mec}$.

\section{D.2.2 DOWNWARD BLOWINC.}

In order to gain insight into the penalty for using suction rather than positive pressure. the relationships between blowing pressure: drop, hral greneration. and mass flow rate

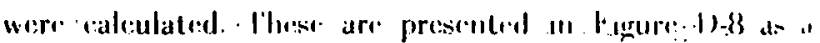
Cunction of maximum wall temperature and in ligrum 11.9 as a function of the outlel coolant temperature l'he p.. erence tase pressure loss is 1.8 psi. Thus the prenalty lon using suction $\$ 0.3 \mathrm{psi}$. Although the same caution applorto blowing with regard to the laminar transition al low masflow rates. choking is not a problem at higher masi now rates of interest. This is shown in Figure 1 ). 10 .

\section{D.2.3 UP.FLOW SUCTION}

Because the coolant docs not reach its maximum l1.m perature until it is near the exit in down-flow there of a savings of pressure loss over up-flow. This is demonstrated in Figure D-11. The reference conditions lor up-flun produce a pressure loss of $2.65 \mathrm{psi}$ or an increase of $0.55 \mathrm{ps}$ over down-flow. 


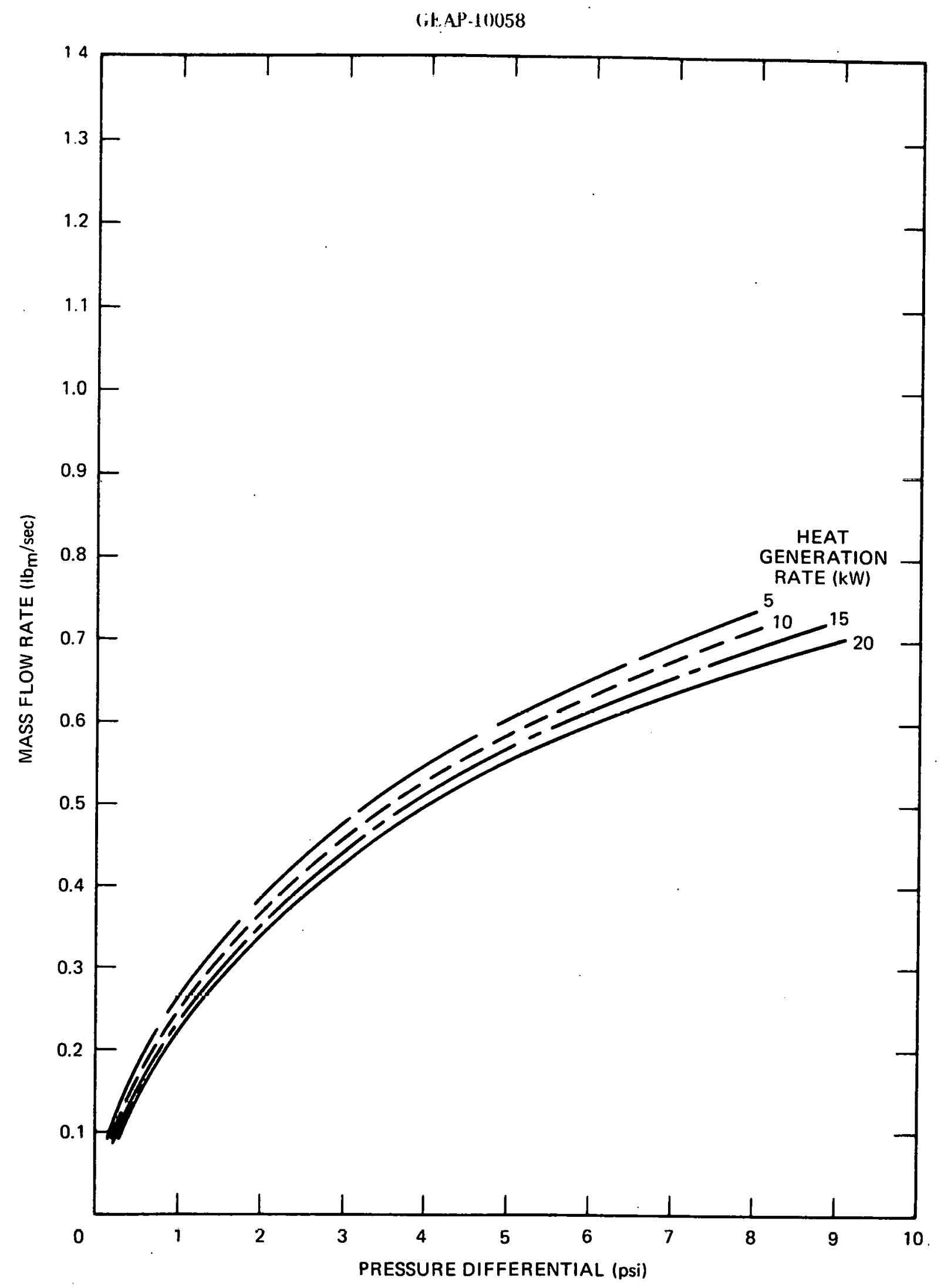

Figure D-5. Mass Flow Rate for Downward Suction as a Function of Pressure Loss 


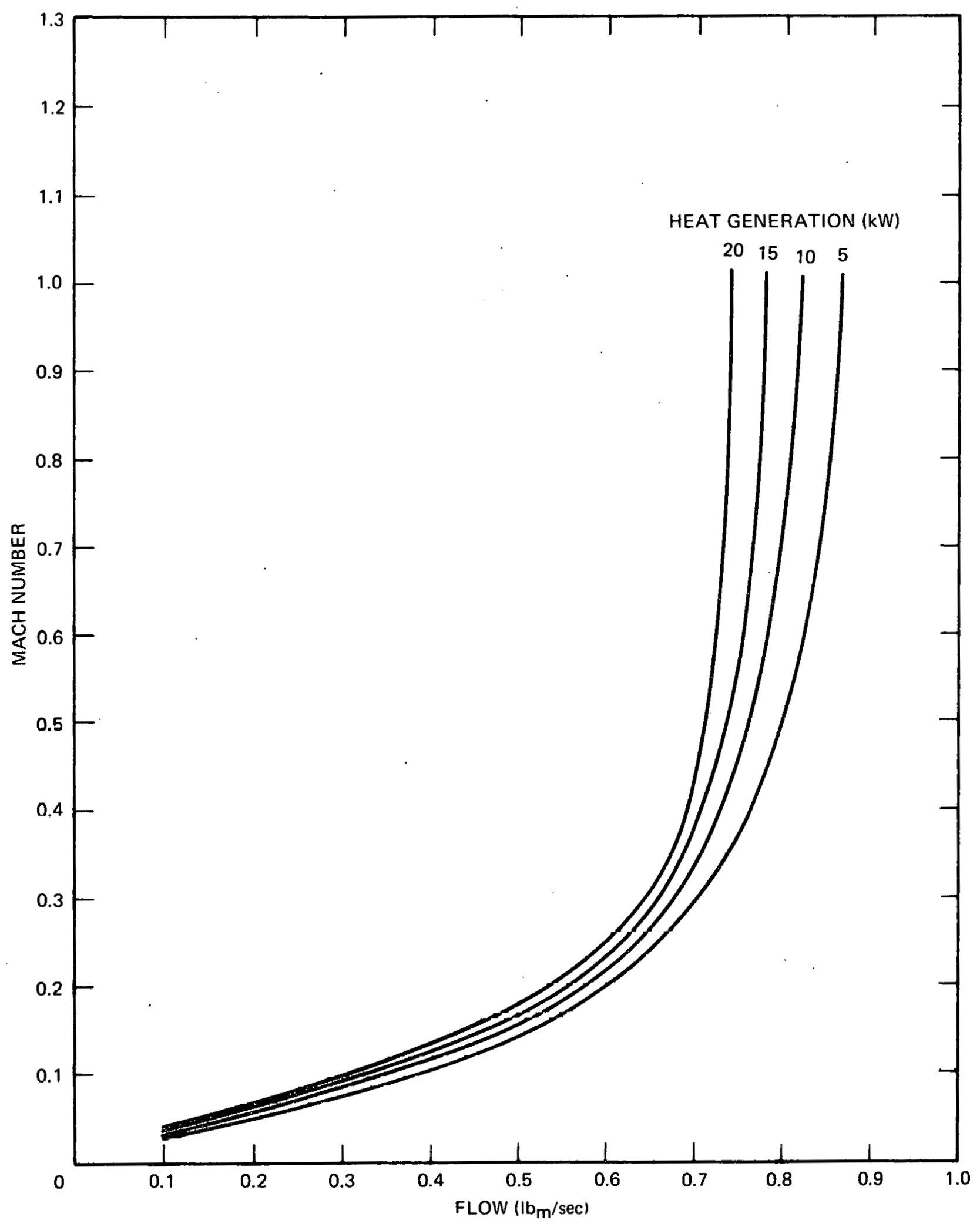

Figure D-6. Exit MACH Number as a Function of Mass Flow Rate for Downward Suction 


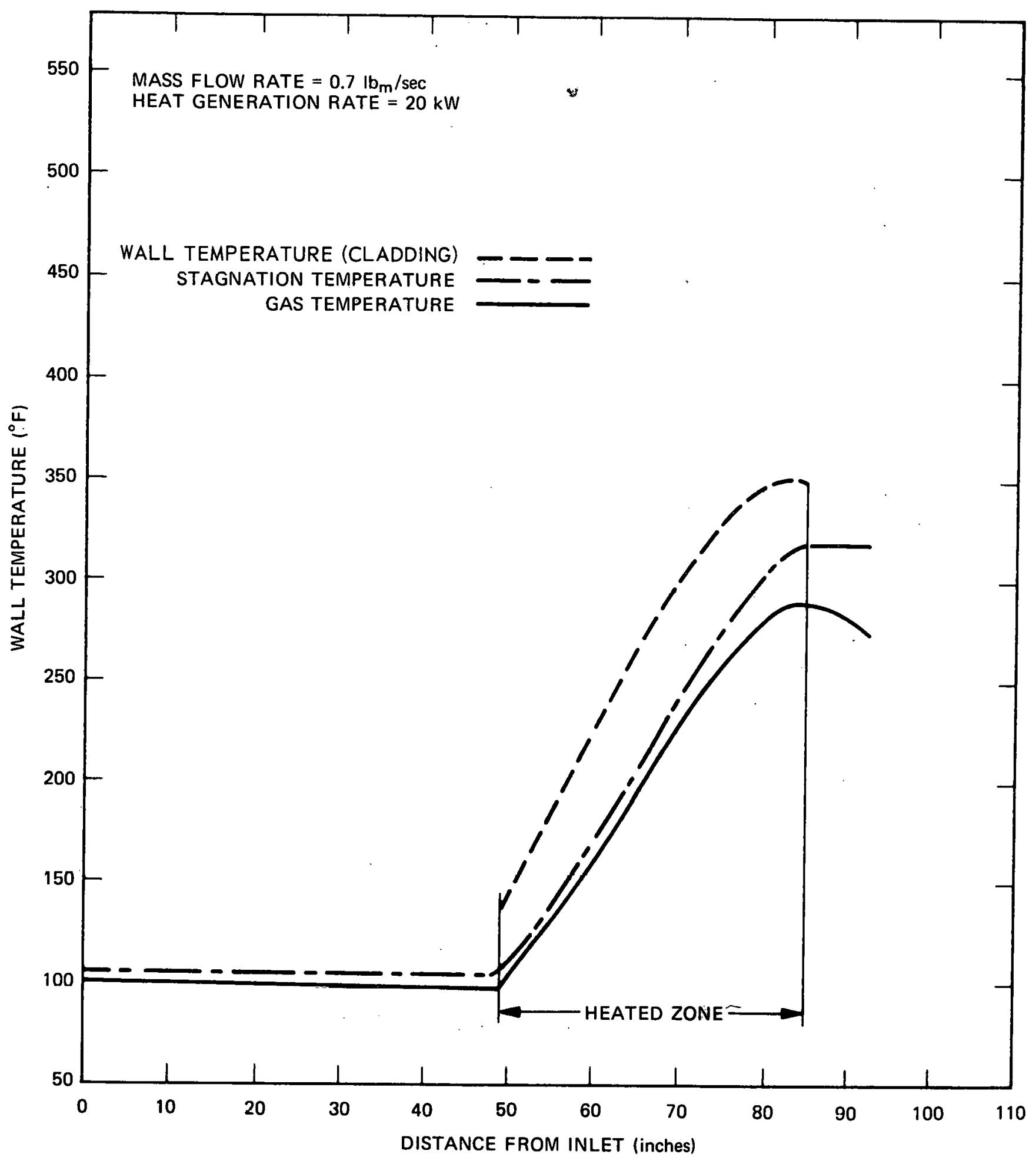

Figure D-7. Wall, Coolant, and Stagnation Temperatures for Downward Suction 


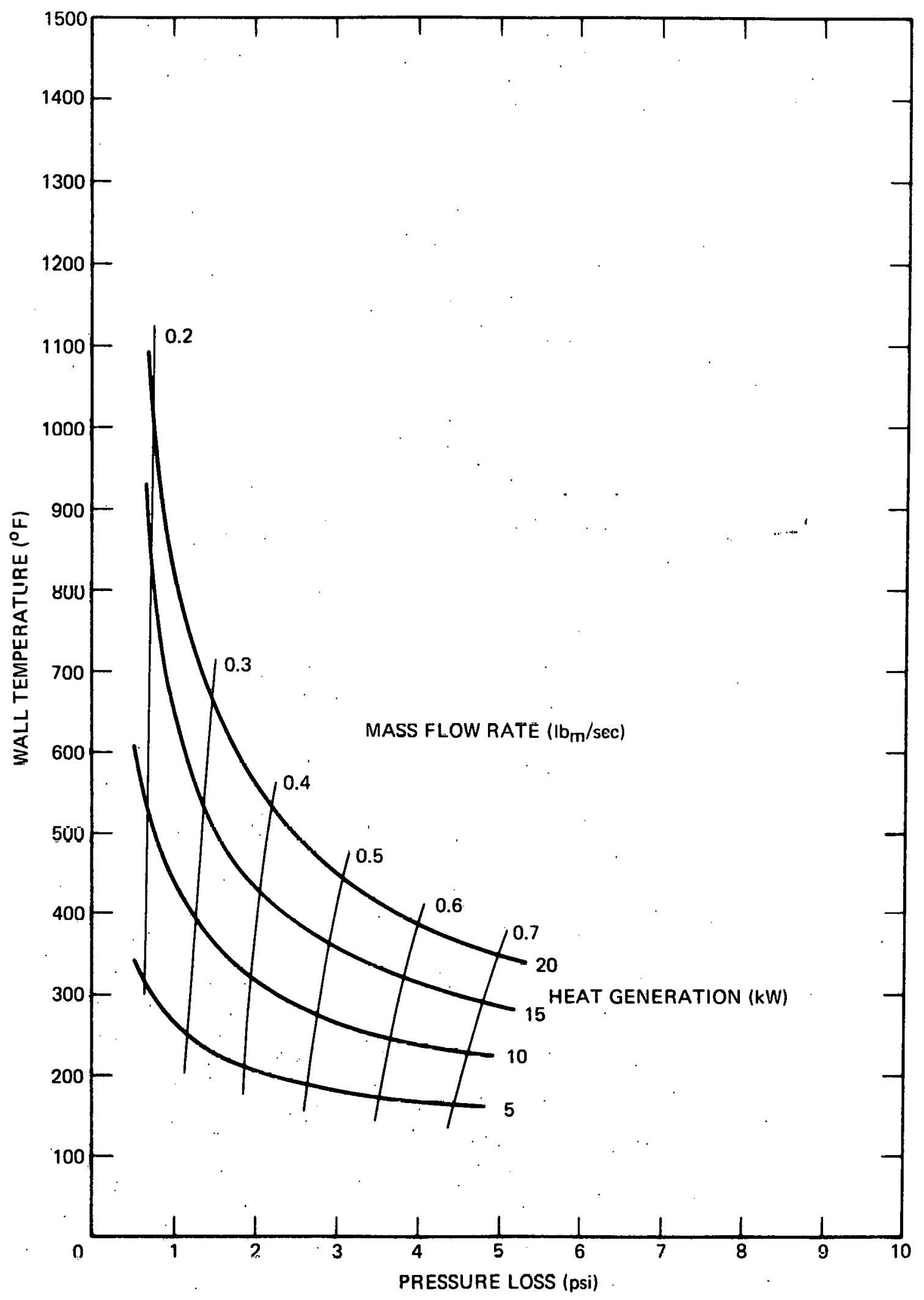

Figure D-8. Wall Temperature as a Function of Pressure. Loss for Downward Blowing 
GEAP-10058

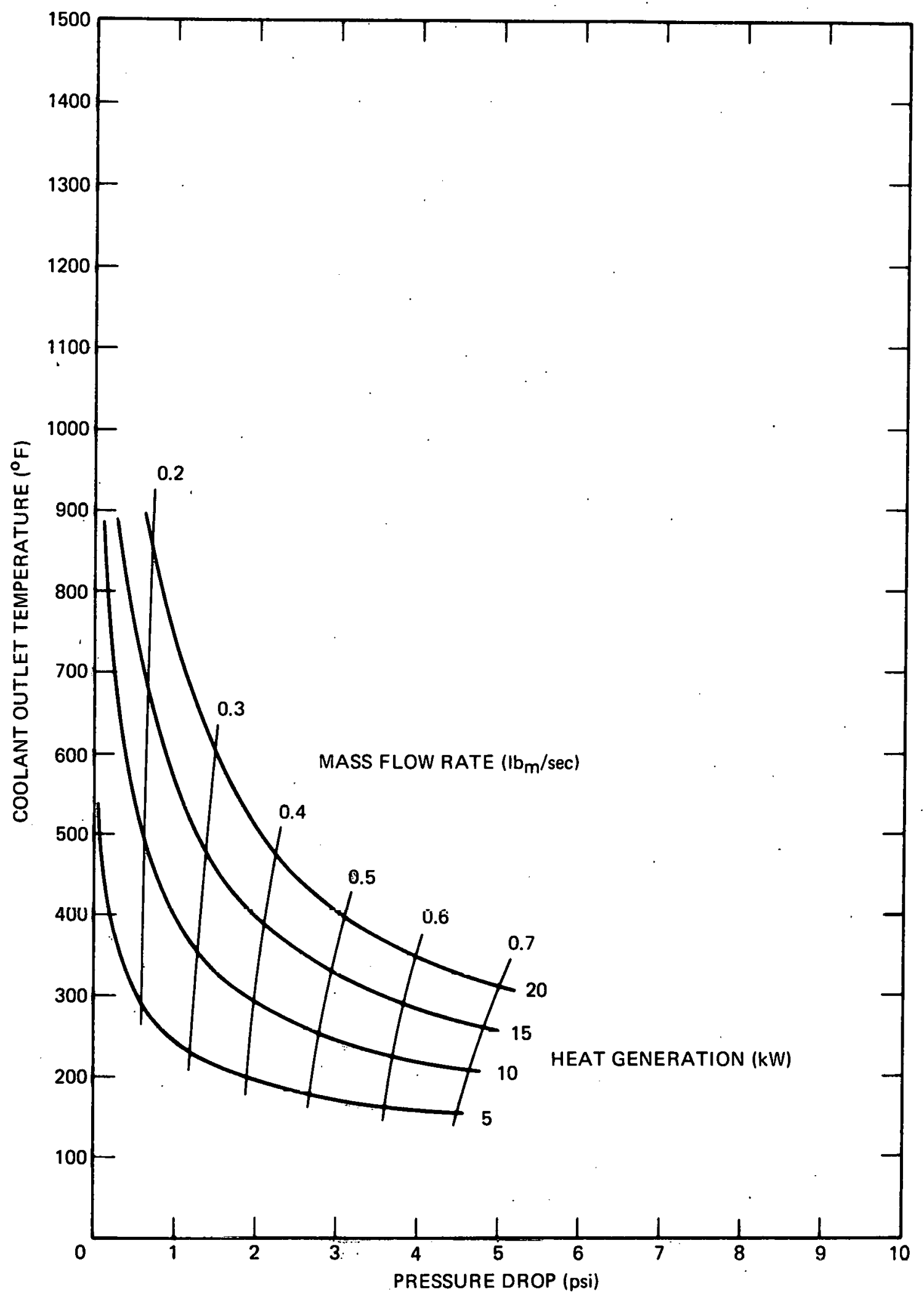

Figure D-9. Coolant Exit Temperature as a Function of Pressure Loss for Downward Blowing 


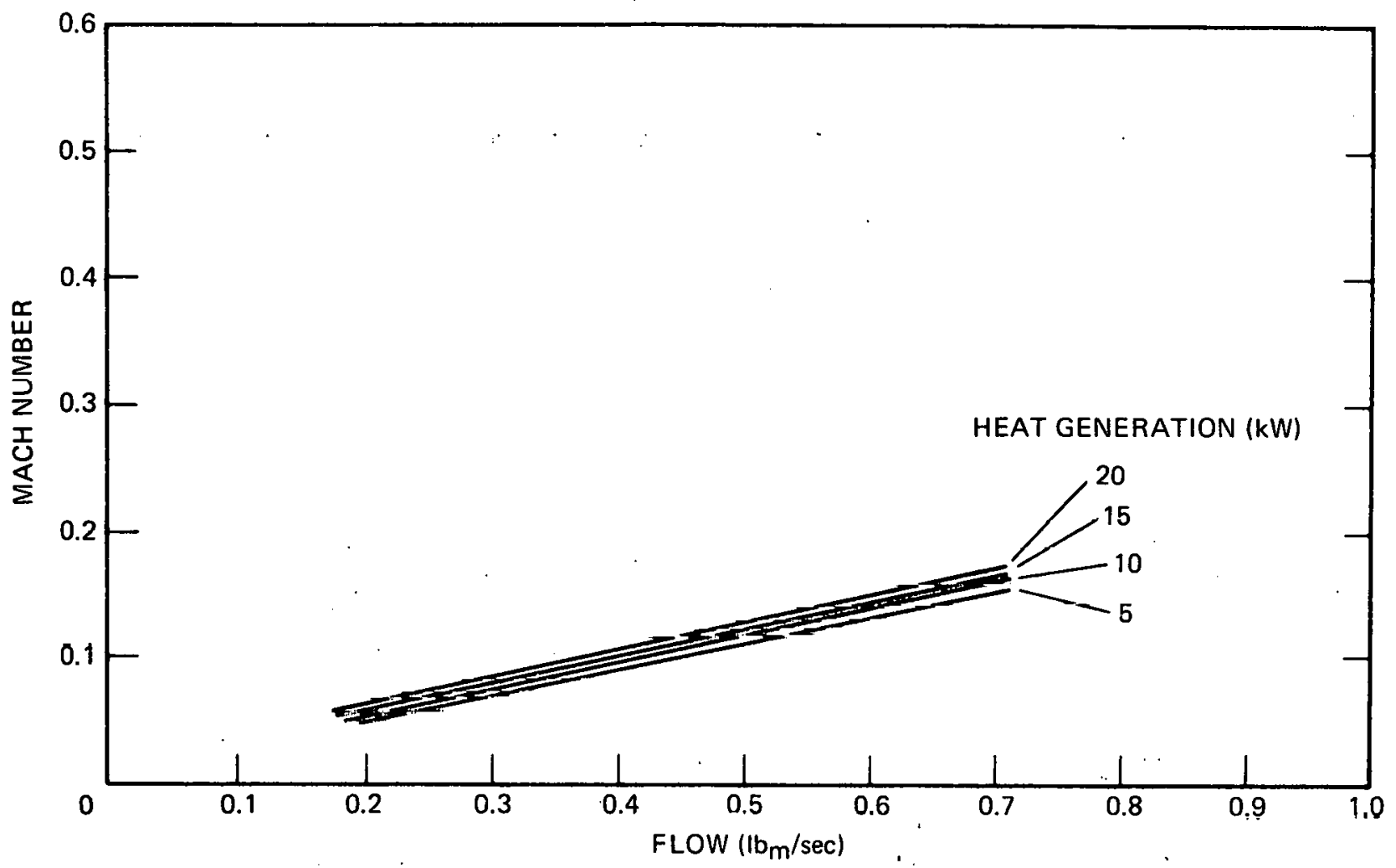

Figure D.10. MACH Number as a Function of Mass Flow Rate for Downward Blowing

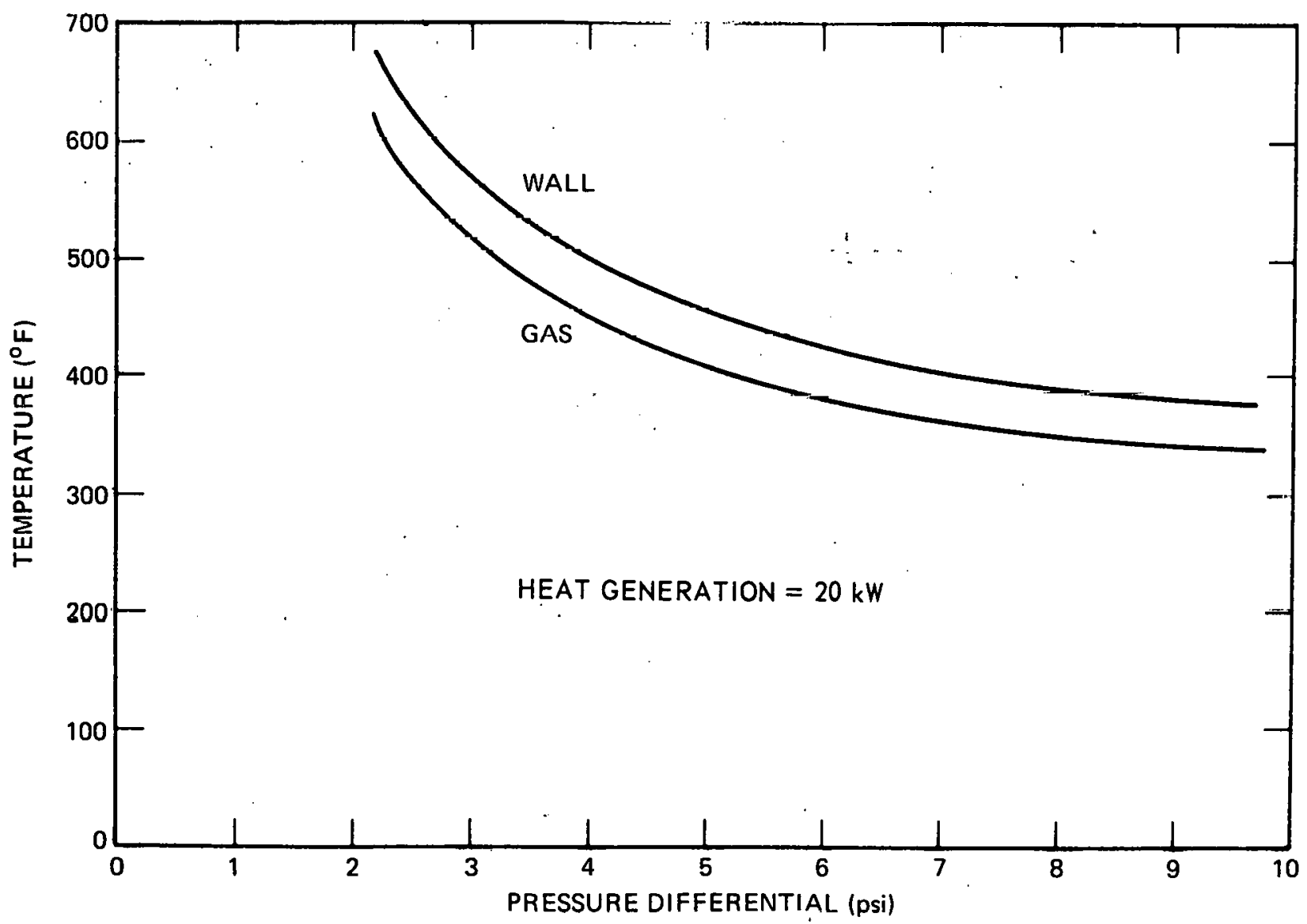

Figure D-11. Wall and Coolant Temperatures for Upward Suction 


\section{APPENDIX E}

\section{HEAT TRANSFER AND FLOW CALCULATIONS}

\section{E.I INTRODUCTION}

The heat transfer and flow characteristics presented in Appendix $\mathrm{D}$ were determined by a computer code $\mathrm{MACH}$. MACH performs a thermal-hydraulic analy sis of a fuel rod bundle cooled by a compressible fluid. MACH is written in time-sharing FORTRAN for the GE 635 computer. It has these capabilities:

- compressible flow

- variablc fluid propcrtics

- nonuniform heat generation

- heated and nonheated sections

- laminar and turbulent flow

A whematic of the geumetry used is shown in Figure E-1.

\section{E.2 CODE STRUCTURE}

The axial length of the fuel bundle is divided into nodes at which the coolant conditions are calculated The number of nodes used is dependent on the physical dimensions of the fuel bundle and on the storage capabilities of the computer. The code as listed in the computer printout below uses 32 nodes for a node spacing of 4 inches. In order to facilitate limited compilation space, extensive use has been made of functions and subroutines which mas be compiled independently.

Properties as a function of temperature are evaluated by linear interpolation from a look-up table in subroutine TABLE. When required, a pressure correction is also made. Because subroutine TABLE may be called repeatedly for different properties at the same temperature, the last position in the table is saved to eliminate the temperature search. Each property is evaluated by a function which sets up the proper indices for subroutine TABLE and performs pressure corrections.

The node analysis is performed by the main program and subroutines UPDATE. NOHEAT and HEAT. The main program controls input and output, and initials variables. It also computes the axial position of the node and tests for a zero heat generation rate. Subroutines NOHEAT and HEAT calculate the change in MACH number. the wall temperature, and the heat generation rate in an unheated or heated increment. The changes in temperature, velocity. and pressure, and their average values over the increment are computed by subroutine UPDATE. Correlations for friction factors are stated explicitly in subroutine UPDATE and, those for the heat transfer coefficients are stated ex. plicitly in subroutine HEAT. These correlations may be changed as required by the user.

Subroutine OUTPUT, contains the print statements and their associated formats.

\section{E.3 REQUIRED DATA}

The required data mav be divided into two types stored data and input data.

\section{E.4 PROPERTY DATA}

All property data is stored in an array. T' $4 B L$, by a DAT 4 statement in subroutine TABLE.

At a pressure of 14.7 psi, the following properties art tab. ulated as a function of temperature:

- density

- dynamic viscosity

- specific heat ratio

- thermal conductivity

- Prandtl number

The first elements of TABL are the absolute temperature at which the properties are referenced. Following the temperatures. one property for each temperature must be given in the order shown above. List all values of one property before listing the next property.

\section{E.5 OTHER DATA}

The remaining data may be either stored or input data. This data is specified by the DATA statement in the main program. In addition, replacement values may be read at execution from the NAMELIST data file The NAMELIST data file is a separate program containing only data and must be saved under the name DATA. The data which may be placed in the data file are shown in Table E-1. The data file must contain values for QBAR and PIN. An example of the use of the data file for the code as listed in the above MACH Code Listing is shown in the following printout: 


\section{MACH CODE LISTING}

1000 FINCTION RHO $(T, P)$
$1010 \mathrm{C}$
DIMENSION OF DENSITY IS LBM/FT**3

1020 CALL TABLE $(T, R H O, 2) ;$ RHO = RHO*P/14.7; RETURN ; END

$1030 \mathrm{C}$

1040 FUNCTION NU(T,P)

1OSOC DIMENSION OF KINEMATIC VISCOSITY IS FT**2/HR

1060 REAL NU.MU; CALL TABLE(T,MU,3); CALL TABLE(T,RHO,2)

1070 $\mathrm{NU}=(14.7 * \mathrm{MU}) /(\mathrm{P} * \mathrm{RHO}) ; \mathrm{RETURN} ; \mathrm{END}$

$1080 \mathrm{C}$

1090 FUNCTIJN GAMMA(T)

$1100 C$ RATIO UF SPECIFIC HEATS IS DIMENSIONLESS

1110 CALL TABLE(T,GAMMA, 4) :RETURN ; END

$1120 \mathrm{C}$

1130 FUNCTION CONDCT(T)

$1140 C$ DIMENSION JF THERMAL CONDUCTIUITY IS B/HR/FT/F

1150 CALL, TABLE(T,CUNDCT, 5) ; RETURN ; END

$1160 \mathrm{C}$

1170 FUNCT I JN PRANTL $(T)$

$1180 \mathrm{C}$ PRANDTL NUMBER IS MIMFNSIOULESS

1190 CALL TABLE(T, PRANTL, 6) ; RETUPN ; END

$1200 \mathrm{C}$

1210 FUNCTION GFUN $(A, B)$

1220 CUMMUN $T(32), T O(32), T W(32), P(32), Q(32), M(32), U(32), X U L(32), R E(32)$, 1230 \& TBAR, VBAR, PBAR, FBAR, LW, DXOL, DE, AH, QBAR, MDOT, CP, I, XOL $1, X O L 2, N O D E S, A F$

1240 REAL LW,NU, MU, MDOT, MBAR,MSQBAR, M, MISQ, M2SQ

1250 GFU: $=1++($ GAMMA $(B)-1 \cdot) * A * A / 2$. :RETURN; END

$1260 \mathrm{C}$

1270 FUNCTIU.V XFUN ( J)

1280 COMMON T( 32$), T O(32), T W(32), P(32), Q(32), M(32), V(32), X U L(32), R E(32)$, 1290 \&TBAR, UBAR, PBAR, FBAR, L K, DXUL, DE, AH, QBAR, MDOT, CP, I, XOL 1 , XOL, NODES, AF 1300 REAL LW, NU, MU, MDOT, MBAR, MSQBAR, M, M ISQ, M2SQ

1310 XFUN $=(X O L(J)-X O L 1) /(X O L 2-X J L 1)$

1320 IF (XFUN・LT・O・) XFUN $=0$.

1330 IF XFUN・GT・1・) XFUN $=1 \cdot$; RETURN : END

$1340 \mathrm{C}$

1350 SUBROUTINE TABLE $(T, V, J)$

1360 DIMENSION TABL $(20,6)$

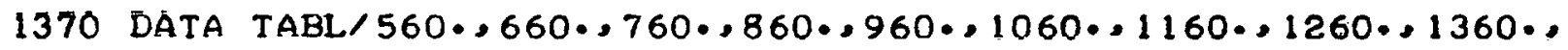

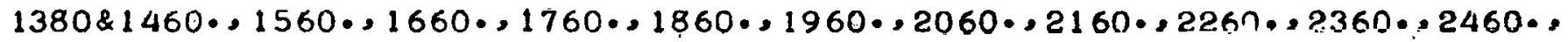
$1390 \& \cdot 094, .076, .068,0062, .057,0052, .048,045,043,041,039,037$. $1400 \& \cdot 033, .030, .02 \%, 0023, .020,0.017,013,010$. $1410 \& \cdot 057, .065, .072, .079, .086, .092, .097, \cdot 103, \cdot 108, \cdot 114, \cdot 119, \cdot 124$, $1420 \& \cdot 128, \cdot 133, \cdot 138, \cdot 142, \cdot 147, \cdot 152, \cdot 157, \cdot 161$, $1430 \& 1.6696,1.6686,1 \cdot 6680,1 \cdot 6678,1 \cdot 6675,1 \cdot 6673,1 \cdot 6671,13 * 1.6670$, 1440\&.0105,.0118,.0131,.0144,.0157,.0170,.0183,.0196,.0209,.0223, $1450 \& \cdot 0260, .0340,0420, .0500,00575, .0620,0750,00830,0910,00990$, 1460\&.6692,.6654,.6622,.6594,.6570,.6552,.6540,.6532,.6528,.6528, $1470 \& \cdot 6530, .6534, .6539, .6546, .6553, .6561, .6571, .6581, .6591 ; .6610 /$ $1480 \&$, TLAST/0./

1490 IF $(T \cdot L T \cdot T A B L(1,1)), 60$ TO 200

1500 IF (T.GT.TABL $(20,1))$ GO TO 300 
$1510 I F(A B S(T-T L A S T) \cdot L E \cdot 1 \cdot)$ GO TO 130

$1520 C \quad T(1) \circ L E \cdot T \cdot L E \cdot T(20)$

$1530100 \quad$ DO $120 \quad I=1,19$

$1540 I F(T \cdot L T \cdot T A B L(I, 1))$ GO TO 130

$1550110 \mathrm{II}=I ; 120$ CONTINUE; $130 \mathrm{I}=I \mathrm{I}$

$1560 \mathrm{C}=(T-\operatorname{TABL}(I, 1)) /(\operatorname{TABL}(I+1,1)-\operatorname{TABL}(I, 1))$

$1570140 \mathrm{~V}=\operatorname{TABL}(I, J)+C *(\operatorname{TABL}(I+1, J)-\operatorname{TABL}(I, J)) ; \operatorname{TLAST}=\mathrm{T}$; RETURN

$1580 \mathrm{C} \quad T \cdot L T \cdot T(1)$

$1590200 \mathrm{C}=(T-\operatorname{TABL}(1,1)) / 100$

$1600 V=\operatorname{TABL}(1, J)+C *(\operatorname{TABL}(2, J)-\operatorname{TABL}(1, J)) ; \operatorname{RETURN}$

$1610 \mathrm{C} T \cdot \mathrm{G} T \cdot T(20)$

$1620300 \mathrm{~V}=\operatorname{TABL}(20, \mathrm{~J})$; RETURN ; END

$1630 \mathrm{C}$

1640 SUBRUUT INE UPDATE(A,B,D)

1650 COMMON $T(32), T O(32), T W(32), P(32), Q(32), M(32), V(32), X O L(32), R E(32)$, 1660\&TBAR, VBAR, PBAF, FBAR, LW, DXOL, DE, AH, QBAR, MDO T, CP, I, XOL 1, XOL2, NODES, AF 1670 REAL LW,NU, MU, MDUT, MBAR, MSQBAR, M, M 1 SQ, M2SQ

$1680 A=T(I-1) * T O(I) * \operatorname{GFUN}(M(I-1), T(I-1)) /(T O(I-1) * G F I N(M(I), T(I)))$

$1690 B=U(I-1) * M(I) * \operatorname{SQRT}(A / T(I-1)) / M(I-1)$

$1700 D=P(I-1) *(V(I-1) * A) /(B * T(I-1))$

$1710 \mathrm{TBAR}=(\mathrm{T}(\mathrm{I})+\mathrm{T}(\mathrm{I}-1)) / 2$

$1720 \mathrm{VBAR}=(V(1)+V(I-1)) / 2$.

$1730 \mathrm{PBAR}=(P(I-1)+P(I)) / 2 \cdot ; R E(I)=3600 *$ VBAR*DE/NU(TBAR, PBAB)

1740 IF(RE(I) $\triangle L T \cdot 2300 \cdot)$ GO TO 100

$1750 \mathrm{C}$ TURBULENT FLOW

1760 FBAR $=.079 / R E(I) * * .25 ;$ GO TO 150

$1770 \mathrm{C}$ LAMINAR FLOW

$1780100 \mathrm{FBAR}=16 . / \mathrm{RE}(\mathrm{I})$

1790. 150 RETURN ; END

$1800 \mathrm{C}$

1810 SUBROUTINE NOHEAT

1820 COMMON $T(32), T O(32), T W(32), P(32), Q(32), M(32), V(32), X O L(32), R E(32)$, 1830 \& TBAR, VBAR, PBAR, FBAR, $L W, D X O L, D E, A H, Q B A R, M D O T, C P, I, X O L 1, X O L 2, N O D E S, A F$

1840 REAI. I.W. NU, MU. MDOT, MBAR, MSQBAR, M, M1 SQ, MESQ

$1850 Q(I)=0$. $\operatorname{TO}(I)=T O(I-1) ; T W(I)=T O(I) ; T E S T=M(I-1)$

$1860 M(I)=$ TEST ; $F=0$.

187050 CALL UPDATE $(T(I), V(I), P(I))$

1880 IF (ABS(FBAR-F)/FBAR・LT. .000001$)$ RETURN

$1890 \mathrm{C}=40 * \mathrm{~L} W * \mathrm{DXOL} / \mathrm{DE} ; \mathrm{MISQ}=\mathrm{M}(1-1) * * 2 ; \mathrm{F}=\mathrm{FBAR}$

1900200 M2SQ $=$ TEST**2; FACTOR $=($ GAMMA $($ TBAR $)+1 \cdot 1) / 2$.

1910 \&*ALOG(MI SQ*GFUN (TEST, T $(I)) /(M 2 S Q$ GFUN $(M(I-1), T(I-1)))$ )

$1920 M(1)=S Q R T(1 . /($ FACTOR+(1)/MISQ) $-C * F B A R * G A M M A(T B A R)))$

1930 IF(ABS(TEST-M(I))/M(I).LT. .000001) GO TO 50

19.40 TEST = M(I); GO TO 200 ; END

$1950 \mathrm{C}$

1960 SUBROUTINE GEAT(XFL)

1970 COMMON $T(32), T O(32), T W(32), P(32), Q(32), M(32), V(32), X O L,(32), R E(32)$, 1980\& TBAR, UBAR, PBAR, FBAR, L W, DXOL, DE, AH, QBAR, MDO T, CP, I, XOL 1 , XOL 2, NODES, AF 1990 REAL LW, NU, MU, MDOT, MBAR, MSQBAR, M, M1SQ, M.2SB

2000 TO (I ) $=$ TO $(1)+.54768 *$ QBAR* $(.866025-\cos (.523598 *(40 *$ XFUN (I)

$2010 \&+1 \cdot 1)) /(M D O T * C P) ; M(I)=M(I-1) ; T E S T=M(I)$ 
MACH CODE LISTING (Continued)

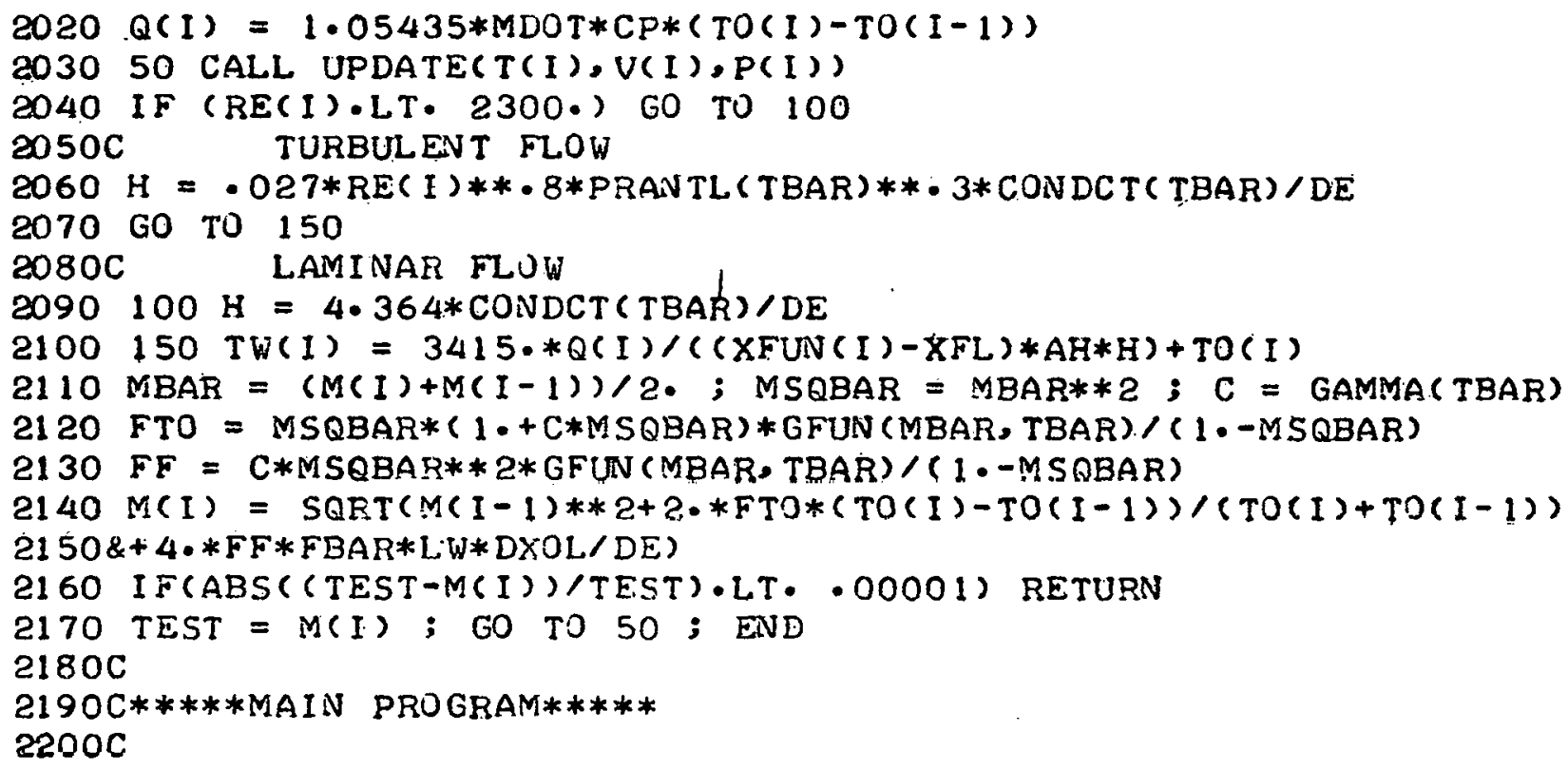




\section{MACH CODE LISTING (Continued)}

2530 FEELL LWI, NU, VII], MDOT, NBAR, MSQBAR, M

2540 PRI.NT 2000, QSAR, (T(1)-460.), (T(NODES)-460.),P(1),P(NODES), MDOT

2550 PRINT $2010,(X O L(I),(T(I)-460 \cdot),($ TO(I $)-460$.), (TH(I)-460.), Q(I),

$2550 \& I=1,(T) E E S)$

2570 PRINT $2020,(X O L(I), M(I), V(I), P(I), R E(I), I=1, N O D E S)$

25802000 HORMATC//17H POWEF...........F10.3,3H KW/

$2590 \& 17 \mathrm{~A}$ INLET TEMP..... $=, F 10,1,6 \mathrm{H}$ DEG F/

$2600217 \mathrm{H}$ EYIT TEMP..... =,F10.1,6H DEG F/

$2610 \& 17 \mathrm{H}$ I NLET PRESS. $\cdots=, F 10 \cdot 3,10 \mathrm{H}$ LBF/SQ IN/

$2620 \& 17 \mathrm{H}$ EXIT PRESS.... =,F10.3,10H LBF/SQ IN/

$2630 \& 17 \mathrm{H}$ MASS FLOW RATE. $=, F 10.4,8 \mathrm{H} \mathrm{LBM} / \mathrm{SEC} / /$ )

26402010 FORMATC 94 POSITION, 3X, $9 H$ GAS TEMP, $3 X, 10 H$ STAG TEMP, $3 X$, 2650\&1OH WALL TEMD, 3X,6H POWER/2X,4H X/L,7X,7H F DEG, 5X,7H F DEG,7X,

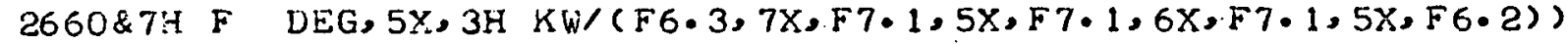
26702020 FURMATC///9H POSITION, 3X,9H MACH NO,,3X,9H UELOCITY, $4 X$, 2680\&9H PRESSURE, 5X,9H REYNOLDS/2X,4H X/L, 19X,7H FT/SEC, 5X, $10 \mathrm{H}$ LBF/SQ IN $2690 \&, 5 X, 7 \mathrm{H}$ NUMBEP/ $(F 6,3,7 X, 117 \cdot 3,2 X, F 10 \cdot 4,5 X, F 8,3,5 X, F 8 \cdot 0))$

¿700 RETURN ; END

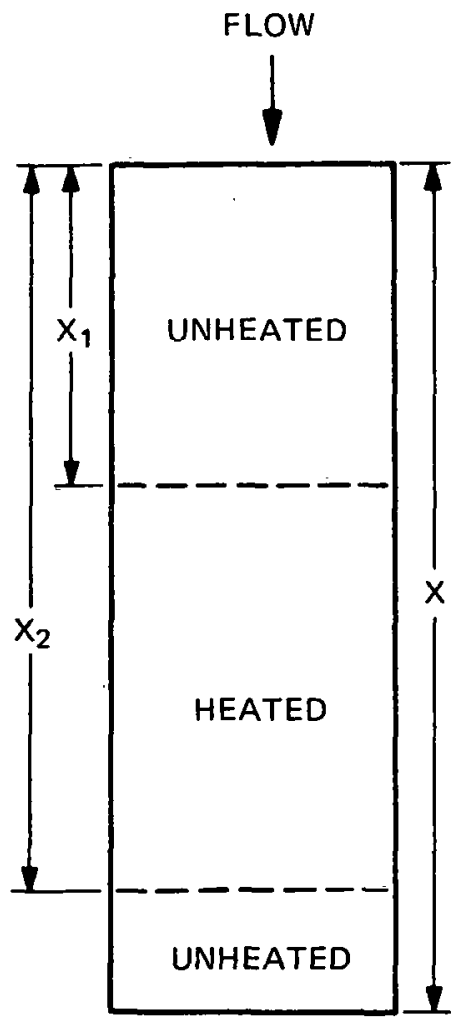

Figure E-1. Fuel Bundle Schematic 
This data would result in tour cases. Parh with a different power. 'The data for a particular case may be placed in more than one line, provided the first variable is preceded by $\$$ IN and the last variable is followed by $\$$

The value of PEX controls the nature of the pressure solution. When PEX $>0$, the inlet pressure is adjusted until the exit pressure equals PEX. If PEX $\leqslant 0$, the inlet pressure is fixed. Thus for suction flow PEX should be given an arbitrary negative value.

\section{E.6 PROGRAM OUTPUT}

The program output consists of the following variables which are tabulated for each node.

- coolant temperature

- stagnation temperature

- wall temperature

- power

- MACH number

- velocity

- pressure

- Reynold's number

The output generated by the first case data in the example of a data file is shown in the output listinge:

EXAMPLE OF A DATA FILE IN MACH

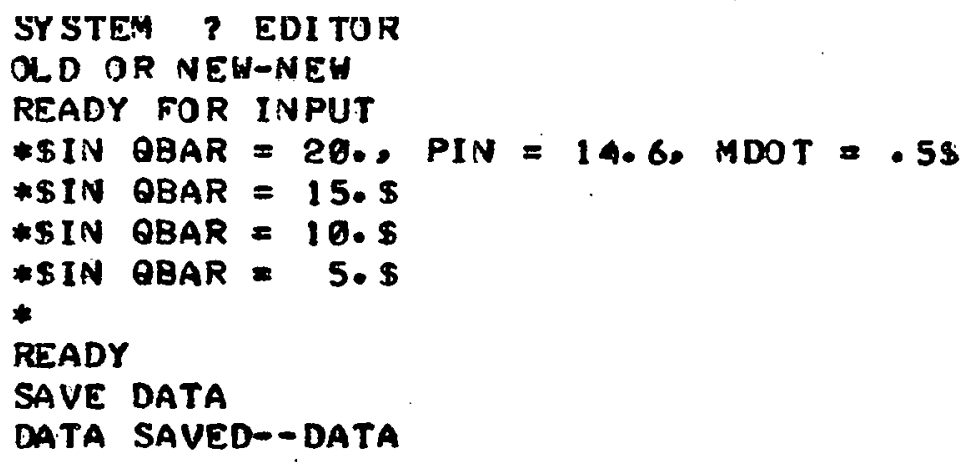

OUTPUT LISTING FOR TYPICAL MACH CASE

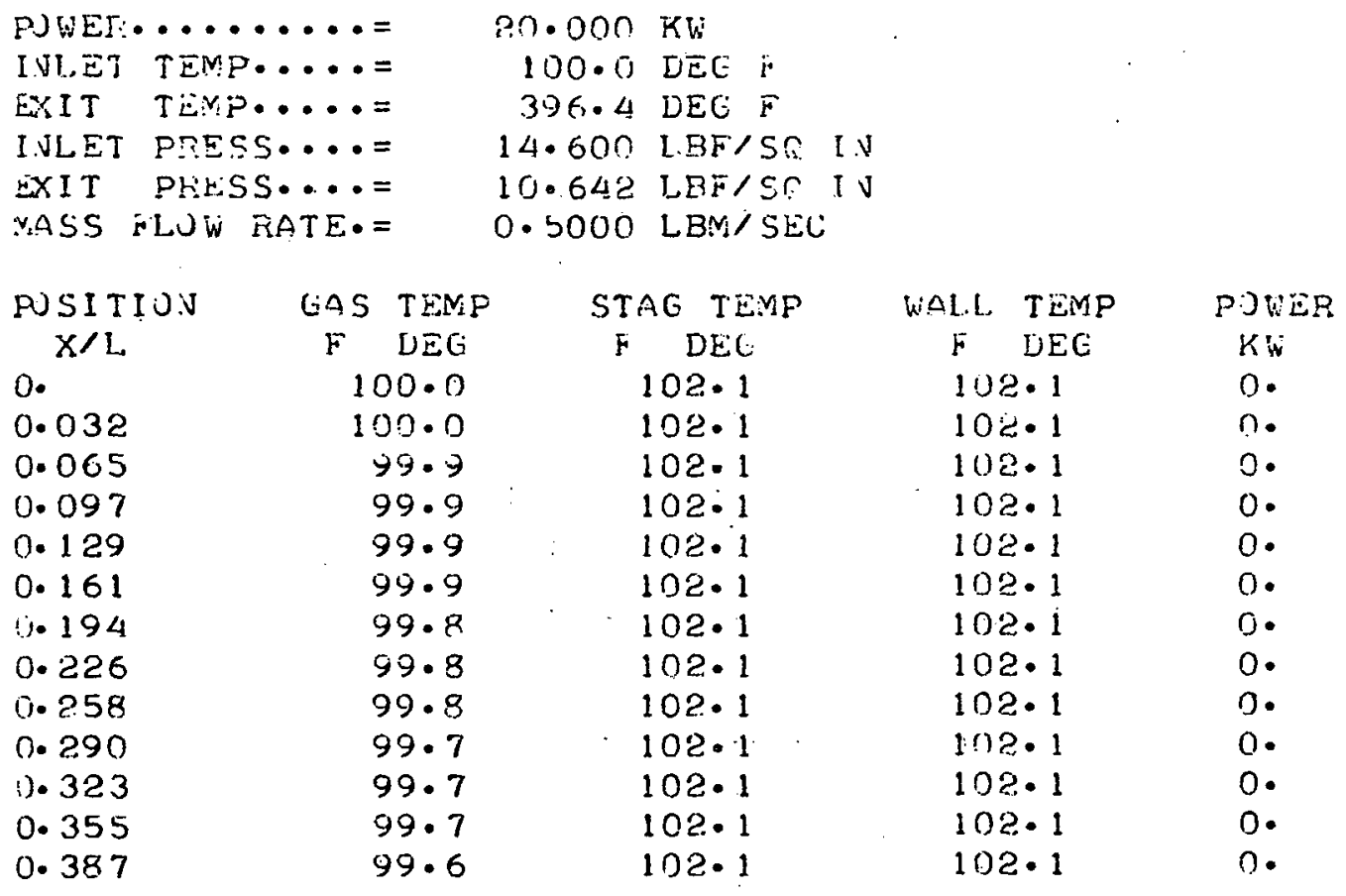


GEAP-10058

OUTPUT LISTING FOR TYPICAL MACH CASE (Continued)

\begin{tabular}{|c|c|c|c|c|}
\hline 0.417 & 99.6 & $102 \cdot 1$ & $102 \cdot 1$ & 0. \\
\hline ?. & $99 \cdot 6$ & $102 \cdot 1$ & $10 \% \cdot 1$ & 0. \\
\hline (1). 484 & $99 \cdot 5$ & $102 \cdot 1$ & $103 \cdot 1$ & 0. \\
\hline U. 516 & 99.5 & $102 \cdot 1$ & $102 \cdot 1$ & 0. \\
\hline 0.548 & $115 \cdot 2$ & 118.0 & $161 \cdot 3$ & 1.05 \\
\hline U. bo 1 & $136 \cdot 2$ & $139 \cdot 3$ & $1+2 \cdot 3$ & $1 \cdot 40$ \\
\hline 0.613 & $160 \cdot 7$ & $164 \cdot 1$ & $226 \cdot 3$ & $1 \cdot 63$ \\
\hline 0.645 & $187 \cdot 8$ & 191.6 & $261 \cdot \%$ & 1.21 \\
\hline $0.67 \%$ & $216 \cdot 8$ & $221 \cdot 0$ & $296 \cdot 3$ & $1 \cdot y 4$ \\
\hline 0.710 & $246 \cdot 7$ & $251 \cdot 3$ & $328 \cdot 0$ & $2 \cdot 00$ \\
\hline $0.74 i$ & $276 \cdot 6$ & $281 \cdot 8$ & $357 \cdot 6$ & 2.01 \\
\hline 0.774 & $305 \cdot 6$ & $311 \cdot 4$ & $384 \cdot 3$ & 1.95 \\
\hline 0.806 & $332 \cdot 9$ & $339 \cdot 3$ & $407 \cdot 0$ & $1 \cdot 84$ \\
\hline 0.839 & $357 \cdot 5$ & $364 \cdot 6$ & $425 \cdot 2$ & $1 \cdot 67$ \\
\hline 0.271 & $378 \cdot 8$ & $336 \cdot 5$ & $438 \cdot 5$ & $1 \cdot 44$ \\
\hline $0.9 .1 \mathrm{~s}$ & $396 \cdot 1$ & $404 \cdot 4$ & $446 \cdot 5$ & $1 \cdot 18$ \\
\hline $0.9: 35$ & $397 \cdot 0$ & $405 \cdot 7$ & $442 \cdot 1$ & 0.08 \\
\hline 0.968 & $396 \cdot 7$ & $405 \cdot 7$ & $405 \cdot 7$ & 0. \\
\hline $1 \cdot(1) n$ & $396 \cdot 4$ & $405 \cdot 7$ & $4 \cap 5 \cdot 7$ & 0 . \\
\hline DUSITIJN & $\because \triangle C H \quad \mathrm{VJ}$ & UELOCI TY & PRESSURE & REYN JLLDS \\
\hline$X / L$ & & FT/SEC & $\mathrm{LBF} / \mathrm{SQ}$ IN & NUMBER \\
\hline 0 & 0.106 & $114 \cdot 6805$ & $14 \cdot 600$ & 8825 \\
\hline 0.032 & 0.107 & 115.3696 & $14 \cdot 512$ & 8825 \\
\hline 0.065 & $0 \cdot 108$ & 116.0714 & $14 \cdot 424$ & 8825 \\
\hline 0.097 & 0.108 & 116.7862 & 14.335 & 8825 \\
\hline 0.12 .9 & 0.109 & 117.5146 & $14 \cdot 245$ & 8826. \\
\hline 0.161 & 0.110 & $118 \cdot 2569$ & $14 \cdot 155$ & 8826 \\
\hline 0.194 & 0.110 & 119.0136 & 14.064 & 8827. \\
\hline 0.226 & 0.111 & 119.7851 & 13.973 & 8827. \\
\hline 0.258 & 0.112 & 120.5721 & 13.881 & 8827 \\
\hline 0.290 & 0.112 & $121 \cdot 3749$ & $13 \cdot 788$ & 8828. \\
\hline $0 \cdot 32.3$ & 0.113 & $122 \cdot 1941$ & $13 \cdot 695$ & 8828. \\
\hline $0 \cdot 355$ & 0.114 & 123.0304 & $13 \cdot 601$ & 8829. \\
\hline 0.387 & 0.115 & $123 \cdot 8842$ & $13 \cdot 507$ & 8829. \\
\hline 0.419 & 0.116 & $124 \cdot 7563$ & 13.412 & 8830 . \\
\hline 0.452 & 0.116 & $125 \cdot 6473$ & $13 \cdot 316$ & 8830. \\
\hline 0.484 & 0.117 & $126 \cdot 5579$ & $13 \cdot 219$ & 8831. \\
\hline 0.516 & 0.118 & $127 \cdot 4889$ & $13 \cdot 121$ & 8831 . \\
\hline 0.548 & 0.121 & $132 \cdot 1651$ & 13.013 & 8725 \\
\hline $0 \cdot 581$ & 0.124 & $138 \cdot 2376$ & 12.896 & 8470 \\
\hline 0.613 & 0.128 & $145 \cdot 3179$ & $12 \cdot 770$ & 8145 \\
\hline 0.645 & 0.132 & 153.2813 & $12 \cdot 636$ & 7766 ' \\
\hline 0.677 & 0.137 & 161.987. & $12.49 \%$ & 7365 \\
\hline 0.710 & 0.141 & $171 \cdot 2400$ & $12 \cdot 338$ & 7225 \\
\hline 0.742 & 0.146 & $180 \cdot 8724$ & $12 \cdot 176$ & 7071 . \\
\hline 0.774 & $0 \cdot 151$ & $190 \cdot 6861$ & 12.005 & 6910. \\
\hline 0.806 & 0.156 & $200 \cdot 4779$ & 11.825 & 6787. \\
\hline 0.839 & 0.161 & $210 \cdot 0429$ & $11 \cdot 637$ & 6684. \\
\hline 0.871 & 0.166 & $219 \cdot 1793$ & 11.442 & 6589. \\
\hline 0.903 & 0.171 & $227 \cdot 6912$ & $11 \cdot 241$ & 6506 \\
\hline 0.935 & 0.174 & $232 \cdot 0004$ & 11.045 & 6465 . \\
\hline 0.968 & 0.177 & $236 \cdot 1805$ & $10 \cdot 846$ & 6464 \\
\hline 1.000 & 0.180 & 940.6019 & $10 \cdot 642$ & 6465 \\
\hline
\end{tabular}


Table E-1

VARIABLES WHICH MAY BE READ

FROM THE DATA FILE IN MACH

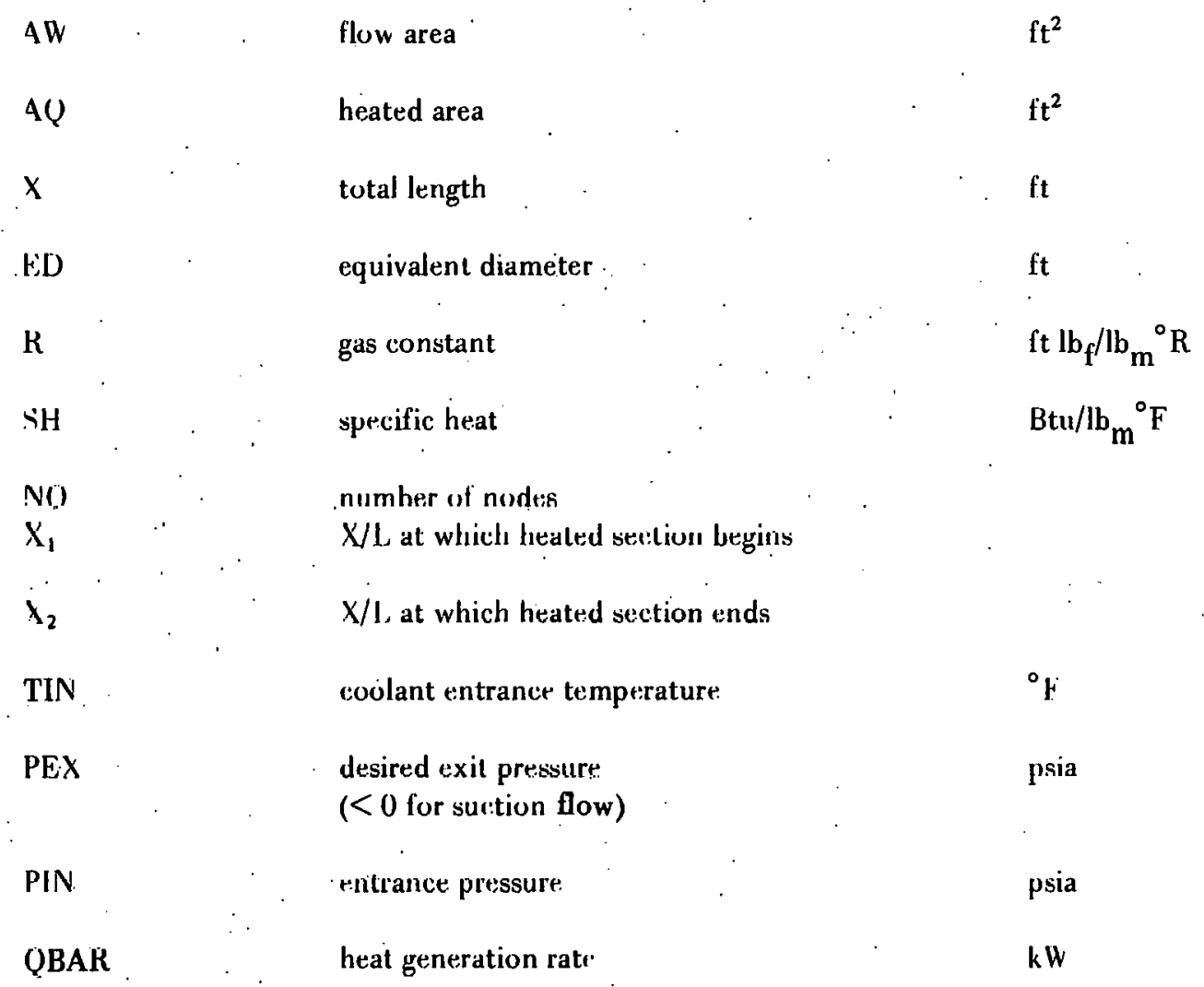

\section{E.7 DEVELOPMENT OF EQQUATINNS}

Consider the flow of a compressible fluid* through a constant area duct with friction and heating as shown in Figure E-1.

The equation of state for a perfect gas is

$P=\rho R T$

or aftor talking logarithmo and differentiating

$\frac{\mathrm{dP}}{\mathrm{P}}=\frac{\mathrm{d} \rho}{\rho}+\frac{\mathrm{d}^{\prime} \mathrm{I}}{\mathrm{T}}$.

Sonic velocity is evaluated by the equation

$\mathrm{C}=\left(\mathrm{g}_{\mathrm{c}} \gamma \mathrm{RT}\right)^{1 / 2}$

which in the log differential form for constant $\gamma$ is

* Shapiro, A. H., "The Dynamics and Thermodynamics of Compressible Fluid Flow," Ronald Press, 1953, Vul. I. $\frac{\mathrm{dr}:}{\mathrm{r}:}=\frac{1}{2} \frac{\mathrm{dT}}{\mathrm{T}}$

By definition, the MACH number is

$M^{2}=\frac{V^{2}}{C^{2}}=\frac{V^{2}}{g_{c} \gamma R^{\prime} I}$.

In log differential form, Equation (5) hersmes

$\frac{d M^{2}}{M^{2}}=\frac{d V^{2}}{V^{2}}-\frac{d T}{T}$.

Applying the conservation of mass to the fuel bun for constant flow rate,

$c:=\frac{\dot{m}}{A} \quad \rho V=$ constant.

Thus,

$\frac{\mathrm{d} \rho}{\rho}: \frac{\mathrm{l}}{2} \frac{\mathrm{dV^{2 }}}{\mathrm{V}^{2}}=0$ 
The energy equation may be written in differential form for a perfect gas as

$d Q=C_{p} T+d\left(\frac{V^{2}}{2 g_{c}}\right)$

Dividing by $\mathrm{C}_{\mathrm{p}} \mathrm{T}$ and using Equation (5),

$\frac{d Q}{C_{p} T}=\frac{d T}{T}+\frac{(\gamma-1)}{2} M^{2} \frac{d V^{2}}{V^{2}}$

Applying the principle of conservation of momèntum to an infinitesimal length increment gives

$-A d P-\tau_{w} A_{w}=\frac{\dot{m} d V}{g_{c}}$.

Substituting the definitions

$\tau_{\mathrm{w}}=\mathrm{f} \frac{\rho \mathrm{V}^{2}}{2 \mathrm{~g}_{\mathrm{c}}}$

and

$D=\frac{4 A}{d A_{w} / d x}$

into Equation (11) yields

$\frac{d P}{P}+\frac{\gamma M^{2}}{2}$ 4f $\frac{d x}{D}+\frac{\gamma M^{2}}{2}=0$

The adiabatic stagnation temperature corresponding to a given fluid state is the temperature the fluid would have if it were adiabatically decelerated to zero velocity. It is defined by the relation

$\mathrm{T}_{\mathrm{o}}=\mathrm{T}+\frac{\mathrm{V}^{2}}{2 \mathrm{~g}_{\mathrm{c}}}=\mathrm{T}\left(1+\frac{(\gamma-1)}{2} \mathrm{M}^{2}\right)$.

In log differential form, Equation (15) is

$\frac{d T_{0}}{T_{0}}=\frac{d T}{T}+\frac{(\gamma-1)}{2} M^{2} \frac{d^{2}}{V^{2}}$.

The seven Equations (2), (4), (6), (8), (10), (14), and (16) give the differential relationships between nine differential variables, $\mathrm{d} \rho / \rho, \mathrm{dP} / \mathrm{P}, \mathrm{dT} / \mathrm{T}, \mathrm{dC} / \mathrm{C}, \mathrm{dM}^{2} / \mathrm{M}^{2} \mathrm{dv}^{2} / \mathrm{v}^{2} \mathrm{dT} / \mathrm{T}_{\mathrm{o}}$, $d Q / c_{p} T$, and $d x / D$. Therefore, the first seven will be chosen as dependent variables while the last two will be specified as independent variables. For the condition of combined friction and heat transfer with the assumption of constant heat flux over the differential increment, unity recovery factor, perfect gas and constant specific heats, the above equations may be solved to give the variation in $\mathrm{MACH}$ number over the increment.

Thus

$\mathrm{dM}^{2}=\mathrm{FT}_{\mathrm{o}} \frac{\mathrm{dT}_{\mathrm{o}}}{\mathrm{T}_{\mathrm{o}}}+\mathrm{Ff}\left(4 \mathrm{f} \frac{\mathrm{dx}}{\mathrm{D}}\right)$

where:

$\mathrm{FT}_{\mathrm{o}}=\mathrm{M}^{2}\left(1+\gamma \mathrm{M}^{2}\right)\left(1+\frac{\gamma-1}{2} \mathrm{M}^{2}\right) /\left(1-\mathrm{M}^{2}\right)$

$\mathrm{Ff}=\gamma \mathrm{M}^{4}\left(1+\frac{\gamma-1}{2} \mathrm{M}^{2}\right) /\left(1-\mathrm{M}^{2}\right)$

In the unheated sections the flow is assumed to be adiabatic so that

$\mathrm{dQ}=\mathrm{dT} \mathrm{T}_{\mathrm{o}}=0$.

Therefore, the variables in Equation (17) may be separated to yield

4f $\frac{d x}{D}=\frac{1-M^{2}}{\gamma M^{4}\left(1+\frac{(\gamma-1)}{2} M^{2}\right)} d M^{2}$

Integration over an increment of length, $\triangle \mathrm{X}$, gives an equation for the exit MACH number,

$$
\begin{aligned}
M_{2}^{2}= & \left\{\frac{(\gamma+1)}{2} \ln \left[\frac{M_{1}^{2}}{M_{2}^{2}}\left(\frac{2+(\gamma-1) M_{2}^{2}}{2+(\gamma-1) M_{1}^{2}}\right)\right]\right. \\
& \left.+\frac{1}{M_{1}^{2}}-\gamma\left[\frac{4 \mathrm{fL}}{\mathrm{De}}\left(\frac{\Delta \mathrm{X}}{\mathrm{L}}\right)\right]\right\}^{-1}
\end{aligned}
$$

where the subscript 1 indicates the inlet of $\Delta \mathrm{X}$ and the subscript 2 indicates the exit.

When the change in MACH number over an increment, $\triangle X$, is known the change in stream properties may be computẹd by

$$
\begin{aligned}
& \frac{\mathrm{T}_{2}}{\mathrm{~T}_{1}}=\frac{\mathrm{T}_{1}}{\mathrm{~T}_{\mathrm{O}_{2}}}\left(\frac{2+(\gamma-1)}{2+(\gamma-1)} \frac{\mathrm{M}_{1}^{2}}{\mathrm{M}_{2}^{2}}\right) \\
& \frac{\mathrm{V}_{2}}{\mathrm{~V}_{1}}=\frac{\mathrm{M}_{2}}{\mathrm{M}_{1}}\left(\frac{\mathrm{T}_{2}}{\mathrm{~T}_{1}}\right)^{1 / 2}
\end{aligned}
$$


$\frac{\mathrm{P}_{2}}{\mathrm{P}_{1}}=\frac{\mathrm{V}_{1}}{\mathrm{~V}_{2}} \frac{\mathrm{T}_{2}}{\mathrm{~T}_{1}}=\frac{\mathrm{M}_{1}}{\mathrm{M}_{2}}\left[\frac{\mathrm{T}_{\mathrm{o}}}{\mathrm{T}_{\mathrm{O}_{2}}}\left(\frac{2+(\gamma-1) \mathrm{M}_{2}^{2}}{2+(\gamma-1) \mathrm{M}_{1}^{2}}\right)\right]^{1 / 2}$

'The energy input over each axial increment is given by the equation

$\frac{\mathrm{dQ}}{\mathrm{d}(\mathrm{X} / \mathrm{L})}=\frac{2 \pi}{3 \sqrt{3}}$ QBAR $\operatorname{SIN}\left[\frac{\pi}{6}\left(\frac{4 \mathrm{X}}{\mathrm{L}}+1\right)\right]$
Equation (25) may be integrated to give

$$
\begin{aligned}
Q= & \frac{Q B A R}{\sqrt{3}}\left\{\operatorname{Cos}\left[\frac{\pi}{6}\left(\frac{4 X_{1}}{L}+1\right)\right]\right. \\
& \left.-\operatorname{Cos}\left[\frac{\pi}{6}\left(\frac{4 X_{2}}{L}+1\right)\right]\right\}
\end{aligned}
$$

the energy input over a heated increment.

\section{Nomenclature for MACH}

\section{Symbol}

\section{Fquatinns}

A

Aw

C

$\mathrm{Cp}$

D

FF

G

ge

$\boldsymbol{\gamma}$

$\dot{\mathrm{m}}$
$\mathrm{SH}, \mathrm{CP}$

CONDCT

$\mathrm{ED}, \mathrm{DE}$

DXOL

FBAR

FTO.

FF

\section{Fortran}

$\mathrm{AW}, \mathrm{AF}$

$\mathrm{AQ}, \mathrm{AH}$

C

GAMMA

$\mathrm{H}$

MDOT

\section{Definition}

flow area

wetted area

heated area

sonic velocity

specific heat

thermal conductivity

equivalent diameter

$\mathrm{X} / \mathrm{L}$ increment for one node

friction factor

influence coefficient for stagnation temperature

influence coefficient for friction

mass flux

dimensional constant

ratio of specific heats

heat transfer coefficient

mass flow rate
Units

$\mathrm{ft}^{2}$

$\mathrm{ft}^{2}$

$\mathrm{ft}^{2}$

$\mathrm{ft} / \mathrm{sec}$

$\mathrm{Btu} / \mathrm{lb}_{\mathrm{m}} \mathrm{F}^{\mathrm{o}}$

$\mathrm{Btu} / \mathbf{f t}-\mathbf{h}-\mathrm{F}^{\circ}$

$\mathrm{ft}$

$$
\begin{aligned}
& \mathrm{lb}_{\mathrm{m}} / \mathrm{ft}^{2}-\mathrm{h} \\
& \mathrm{lb}_{\mathrm{m}} \mathrm{ft} / \mathrm{lb}_{\mathrm{f}} \mathrm{sec}^{2}
\end{aligned}
$$

$\mathrm{Btu} / \mathrm{ft}^{2}-\mathrm{h}-\mathrm{F}^{\circ}$

$\mathrm{Ib}_{\mathrm{m}} / \mathrm{sec}$ 


\section{Nomenclature for MACH.(Continued)}

\section{Equations}

H: :1

P

$\rho$

Q

$\mathbf{R}$

$\mathrm{T}$

To

$\pi w$

V

\section{Symbol}

Fortran

$M$

MBAR

ML

No. NODES

NI

$\mathbf{P}$

PIN

PEX

PBAR

PRANDTI.

RH()

Q

R

$\mathrm{RE}$

$\mathrm{T}$

TO

$T W$

TIN

TBAR

v

VBAR
Definition

Units

MACH number

average value of MACH number over increment.

dynamic viscosity

$\mathrm{Ib}_{\mathrm{m}} / \mathrm{ft}-\mathrm{h}$

number of axial nodes

kinematic viscosity

$\mathrm{ft}^{2} / \mathrm{h}$

pressure:

psia

inlet pressure:

psia

exit pressure

psia

average pressure over

increment

psi

Prandtl number

density

$\mathrm{lb}_{\mathrm{m}} / \mathrm{ft}^{3}$

heat generation rat:

kW

gas constant

$f t b_{f} / l_{b_{m}} R^{\circ}$

Reynold's number

coolant temperature

${ }^{\circ} \mathrm{R}$

stagnation temperature

${ }^{\circ} \mathrm{R}$

wall temperature

${ }^{\circ} \mathrm{R}$

coolant inlet temperature:

${ }^{\circ} \mathrm{F}$

average coolant temperature

${ }^{\circ} \mathrm{R}$

over increment

shear stress at the wall

is

'coolant velocity

psi

$\mathrm{ft} / \mathrm{sec}$

$\mathrm{ft} / \mathrm{ser}$ 
GEAP-10058

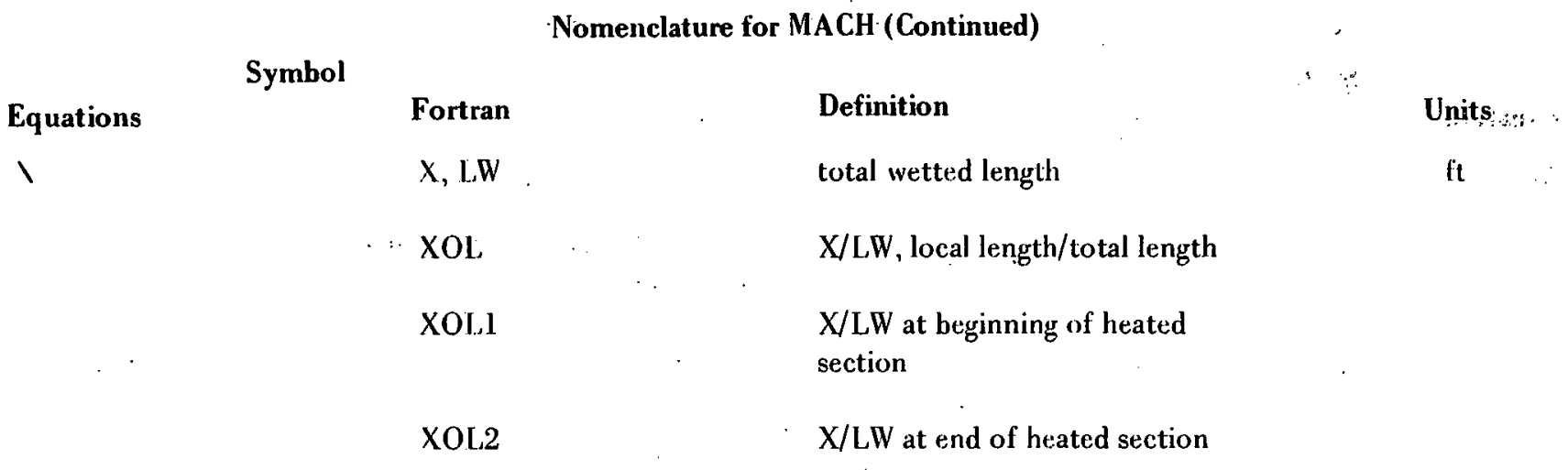




\section{APPENDIX F}

\section{EMERGENCY COOLING BY RADIATION}

\section{F. I RESULTS}

In the event forced convection cooling is lost, the fuel bundle would be cooled only by radiation. Free convection and gaseous conduction offer negligible heat transfer. The average steady-state surface temperature for the center pin of a 217-pin bundle is shown in Figure F-l for heat transfer by radiation only. For the reference heat generation rate of $20 \mathrm{~kW}$, the resulting temperature would be well above the design limit of $1500^{\circ} \mathrm{F}$. Assuming a 1.2 peak-to-average axial power factor, cladding melting can be assumed for any surface emissivity. Assuming a typical emissivity of 0.2 for irradiated fuel pins, the heat generation rate must be allowed to decay to $1.6 \mathrm{~kW}$ if the design limit temperature is not to be exceeded during a loss-of-coolant accident. A radial profile through a bundle generating $20 \mathrm{~kW}$ is shown in Figure F-2.

\section{F.2 METHOD OF ANALYSIS}

The analysis by Watson* was followed with the exception that a hexagonal rather than a square array was used. Each pin can "see" its six adjacent neighbors and, for the reference pitch-to-diameter ratio, six pins in the second row. The view factor calculation for the adjacent pins is identical to that presented in reference 6 for square arrays. Because a pin cannot "see" beyond the second row, the view factor for the outer pins is the difference between unity and the view factor for the adjacent pins.

* Watson, J. S., "Heat Transfer from Spent Reactor Fuels During Shipping: A Proposed Method for Predicting Temperature Distribution in Fuel Bundles and Comparison with Experimental Data," 1963, (ORNL-3439).
Gray body radiation factors were calculated from the expression

$\mathcal{F i j}_{\mathrm{ij}}=\frac{1}{\frac{1}{\mathrm{~F}_{\mathrm{ij}}}+2\left(\frac{1}{\epsilon}-1\right)}$

where:

$\mathfrak{F}_{\mathrm{ij}}=$ gray body radiation factor

$F_{i j}=$ view factor between pins $i$ and $j$

$\epsilon=$ emissivity

Equation (1) assumes that only surfaces $i$ and $j$ exchange energy. Temperatures were calculated by the equation

$T_{i}^{4}=\frac{\frac{Q_{i}}{A \sigma}+\sum_{j=1}^{N} \jmath_{i j} T_{j}^{4}}{\sum_{j=1}^{N} \jmath_{i j}}$

where:

$\mathrm{T}=$ absolute temperature

$Q=$ heat generation rate

$A=$ surface area

$\sigma=$ Stefan-Boltzman constant

Temperatures for a 60 degree section and the associated channel wall were determined by the method of relaxation. 


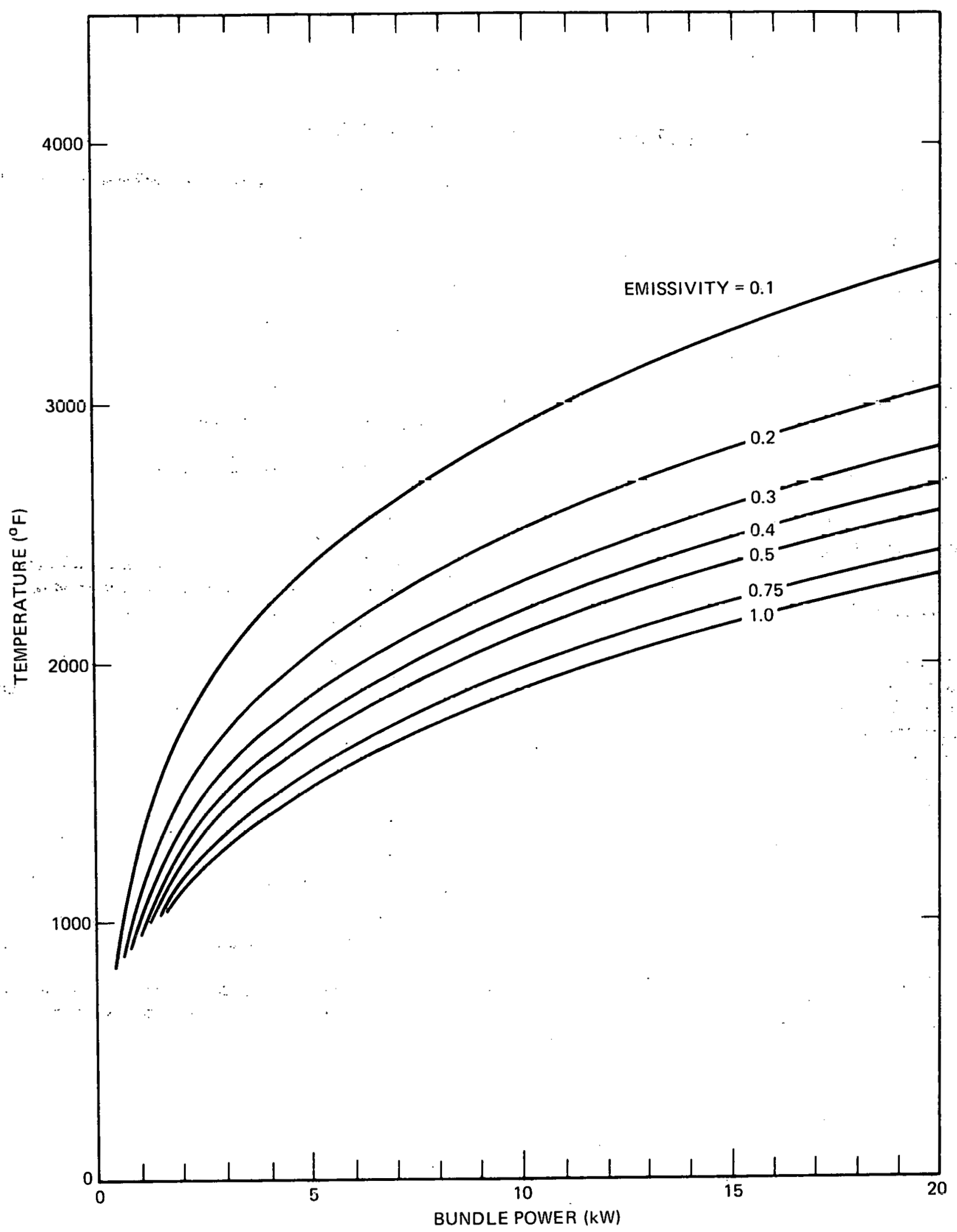

Figure F-1. Center Tod Temperature in a Hexagonal Bundle (217 Rods)Cooled Only by Radiation 


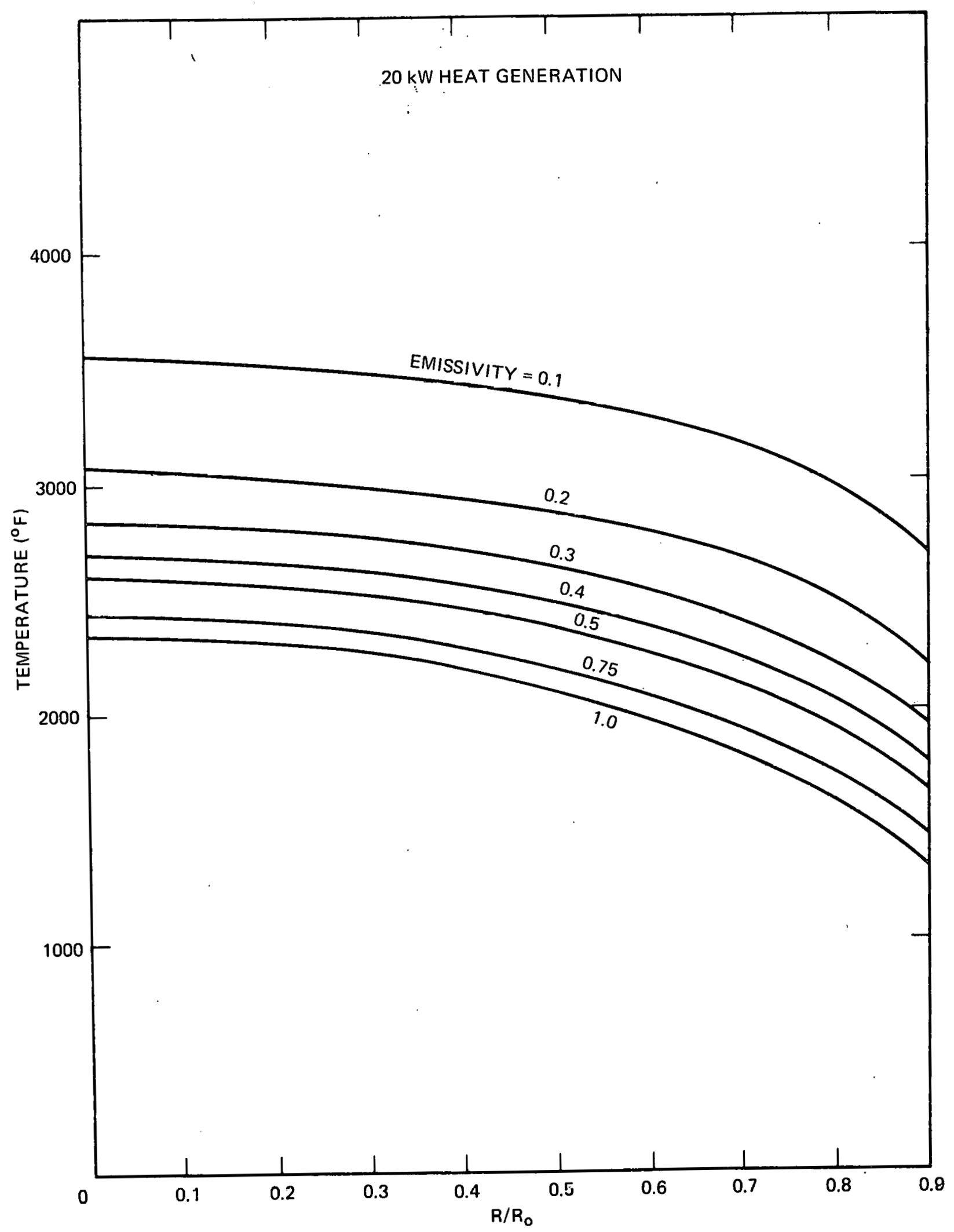

Figure F-2. Radial Temperature Profiles in a 217 Pin Hexagonal Bundle Cooled Unly by Radiation 


\section{APPENDIX G}

\section{FUEL DISASSEMBLY STATION}

Although the design of the fuel disassembly station is not part of this study, its interface with the portable axial gas cooling system must be examined to assure compatibility. The following is a very brief description of the fuel disassembly station.

To disassembly a fuel assembly, one must first remove the hexagonal shroud and then remove individual fuel pins. If reuse of the fuel assembly is anticipated, the fuel pins must be returned to the assembly and the hexagonal shroud replaced. Adequate gas cooling must be maintained during all of thesc opcrations. Four modes of cooling are used:

- axial gas cooling, when the hexagonal shroud is in place

- transition and axial gas cooling when the hexagonal shroud is partially removed

- transverse gas cooling when the hexagonal shroud is removed

- cooling of individual fuel pins after removal from the assembly. In this case, forced gas cooling may not be necessary.

The sequence of cooling and disassembly operations differs for driver fuel assemblies and instrumented test fueled assemblies. Driver fuel assemblies are constructed with the fuel pins attached to the structure at the lower end of the hexagonal shroud. Removal of the driver fuel shroud must be done with upward suction applied at the top of the assembly. The bottom end of the shroud is first cut immediately above the point of fuel support. The shroud is then removed in an upward direction. As the heat generating region becomes exposed, a transverse suction cooling port is uncovered utilizing both transverse and axial cooling methods. After the shroud is raised to a point above the heat generating region, the axial gas flow may be stopped, and cooling is entirely by transverse suction.

Transfer of the driver fuel aysimbly to the disassembly slation is done in the same manner as other fuel transfers, except that connection must be made to an upper suction device before removal of the portable axial gas cooling manifold. This upper suction device. as well as the transverse cooling device. is considered to be a part of the disassembly station.

Fuel test assemblies with contact instrumentation will normally be constructed with the fuel pins connected to the upper instrumentation extension. Removal of the shroud must be done with downward suction applied at the bottom of the assembly. The fuel and instrumentation assembly is held at the top end, as the shroud is removed in a downward direction.

Axial gas cooling with the instrumented assembly can be provided entirely by the portable axial gas cooling manifold, with any one of the following three sequences:

- Transfer the instrumented test fuel assembly to the disassembly station with the assembly remaining at approximately the same vertical elevation as it is received from the transfer cell. Subsequent removal of the fuel would be accomplished in an upward direction with the shroud remaining fixed. This procedure may be undesirable, if it increases the required overhead height of the cell.

- Transfer the instrumented fuel assembly into the disassembly station as above, but lower the suction manifold as the shroud is removed downward. This method has the disadvantage of requiring the flexible suction hose to accommodate a considerable amount of vertical motion.

- Attach the suction manifold to a flange on an enclosed shroud removal device, as shown in Figure G-1. This enclosed chamber is exposed to the pressure of the suction manifold when the valve of the suction manifold is opened. A mechanical device withın this chamber would be equipped to attach to the shroud and pull it down. Downward suction would be stopped after the heated section of the fuel assembly is uncovered and cooled entirely by transverse flow. 


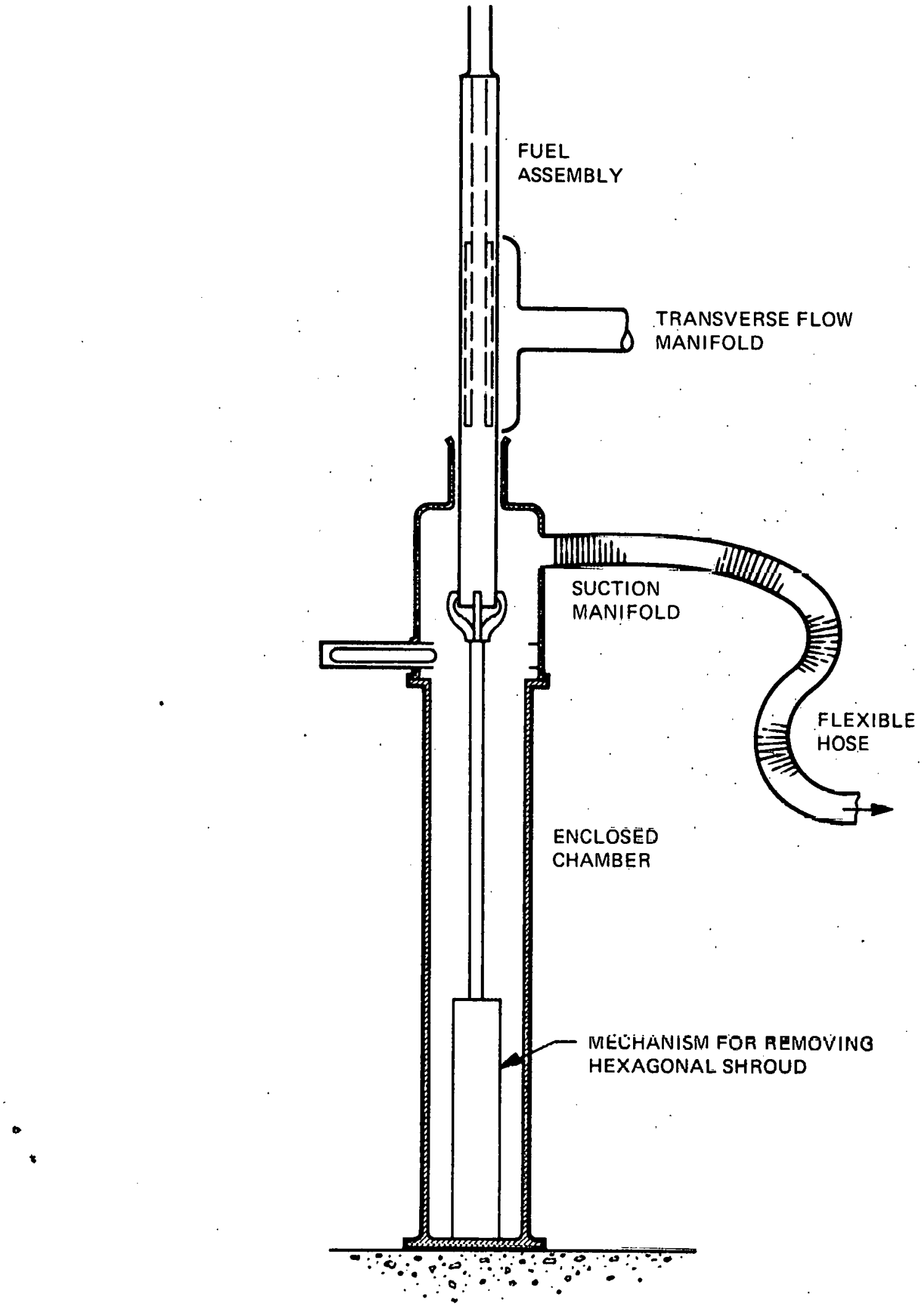

Figure G-1. Method for Utilizing Suction Manifold for Providing Down Flow Cooling During Removal of Shroud 


\section{APPENDIX H}

\section{DEVELOPMENT PROGRAM}

Appendix $\mathrm{J}$ describes the very limited relevant experience available to apply to the FFTF axial fuel cooling equipment. In addition to refining the analyses and design described in this conceptual study report. development is indicated in the areas of sealing, sodium removal, argon cleanup and mechanical handling.

\section{H.1 SEALING}

A seal must be made between the suction manifold and the hexagonal surface of the fuel assembly. 4 considerable amount of bypass leakage past the seal mav he permissible if sufficient pumping capacity is provided. although it would be desirable $t o$ keep this leakage to a minimum.

Two basic methods of sealing can be used a rigid seal. such as a labyrinth, and a flexible acal which follows the contour of the fuel bundle surfacr. In the case of a rigid seal, it must either be sufficiently long to span between two adjacent contact pads on the driver fuel assembly or else be made to accept a large clearanis gap over part of the withdrawal distance.

A flexible seal would be made to accommodate the varying bundle diameter between the contact pads and the rest of the fuel assembly. This flexible seal can be made to utilize the negative pressure to help minimize leakage.

In addition to investigating the amount of leakage flow past the seals, careful observation must be made of any situation which could lead to flow-induced vibration of the seal.

\section{H.2 SODIUM REMOVAL}

The degree of sodium removal under condition: of high argon flow should be investigated. The amount of sodium retention on the surfaces of the tuel is of concern in deciding whether or not further rleaning will be required before fuel examination. The sudium remaining in the upper (inlet) part of the fuel assembly will tend to freeze soov afles lluw is eslablished.

\section{H.3 ARGON CLEANUP}

The argon gas enters the pumping system at about $500^{\circ} \mathrm{F}$ and will contain some sodium vapor. The degree to which such vapor will be removed on heat exchanger surfaces and the amount which will pass through and be caught on filter surfaces should be noted.

\section{H.4 MECHANICAL HANDLING}

Movement of driver fuel and closed loop and open loop assemblies in and out of the suction manifold while maintaining proper cooling should be studied. Additionally, movement of the suction manifold from one station to another while maintaining coolant flow through a flexible hose or articulated suction tube should be evaluated under nonradioactive conditions. Maintainability of the cooling and pump equipment, instrumentation, and suction manifold should all be evaluated as a part of this testing program.

To perform the evaluation of items described in Table H-1, it is suggested that a testing program be carried out on a suction manifold and pumping and cooling system equipment which will ultimately be used in the FFTF. The manifold. flexible hose, pumping rquipment (separators, heat exchangers and filters) would thus be full scale equipment. The rifuipment would be tested in a temporary steel test chamber which simulates a portion of the fuel transfer cell. An electrically heated mock-up driver fuel assembly would be used in conjunction with a full size sodium pot in a mock-up transfer port. The electrically heated driver fuel assembly would have sufficient heat capacity to simulate the full heat load under decay heat conditions of the actual driver assembly It might or might not be exactly prototypical of the geometrical arrangement of the driver assembly. Tests would be performed with instruments on the mock-up fuel assembly and at positions in the suction manifold and pumping system which simulate the actual unstrument sensors to be used in the FFTF suction manifold and pumping system.

With the equipment noted, it will be possible to test the pcrformance of the heat removal equipment as the mock-up assembly is raised from the sodium pot and cooled by the gas corling system. Different types of seals in the suction manifold ran be tested for their effectiveness in minimizing bypass fluw. The degree of sodium removal under different simulated decay heat conditions can be evaluated and the argon cleanup with the separator can be studied. Modification to the equipment can be made in accordance with needs developed during the testing program. 
Table H-I

ESTIM ATED FINANCIAL AND MANPOWER NEEDS

FUK FFTF FUEL COOLING STATION R \& D

Title

Facility

Requirements
Cost (in $\$ 1000)$

$\begin{array}{cc}\begin{array}{c}\text { Equipment } \\ \text { and }\end{array} & \begin{array}{c}\text { Operating } \\ \text { or }\end{array} \\ \text { F acilities }^{\star \Delta} & \text { Engmeering }\end{array}$

None

7.5

150

Vune

None

visne

tane

h()
I.ab Shop
vone
Lab I. III
Instrument:

lath 1 all

l.at, $1 .-11$

Lab · c lell

Lath Shop

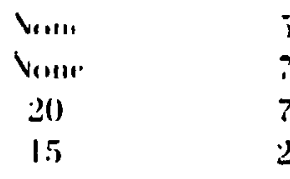

0.7

U.3

0.3

0.5

3.0

$1 . i$

$1 . .7$

V(m). 50

$4(1$

1.0

\section{FUR FlTH ISF:}

vone:

Tutals
375

* The use of huilding space for cell sirtup and test stands is assumir d

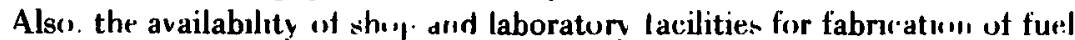
mock-ups and the avalabilitv "if a power supply tor rlectro al heatıng are assumed

** Contingency if initial design requires ime dificatıon.

In addition to the heat Inad simulation it may be desirabl. to simulate the actual geometry of a fuel assembly and test the flow chararteristic: of the system with alternative seals. Ti, accomplish this an artual geometrical mock-up of the driver assembly and lossed arid open loups ran bre falb. ricated and tested. In this imstance water can be userl as the liquid surface from which the fuel dssemblipes are remoured. vo heating would be affected dunng thrse lest. dud in tormatuon on pre:sur drip-flow rharacteristics would be the major result $f$ werond nbjertive if thes tests would be tu determine the tle chilits of handling at the equipment and the rase with whorh mantenances icould be carried sul.

An estimate of the manpower and financial needs for this program are givent in Table $\mathrm{H} . \mathrm{I}$. and o program schedule $\mathrm{k}$ given in Table $\mathrm{H}_{2}$ 
GF.4P-10058

Table H-2

SCHEDULE FOR FFTF FUEL COOLING STATION EQUIPMENT R\&D

Years from Start of Program

0

1

2

DESIGN

Preliminary Scope

Prototype Assemblies

Modification

FABRICATION. PROCUREMENT. AND INSTALLATION

COMPONENT TESTS

MODIFICATION OF COMPONENTS FOR FFTF LSF 


\section{APPENDIX I}

\section{INSTRUMENTATION}

In order to investigate the response and adequacy of instrumentation, Table I-l was developed. It shows an approximation of the readings that would be obtained with the instruments under normal conditions and under various conditions of malfunction. The numbers are only approximate and represent a somewhat higher pressure drop than the reference. The table, however, is representative and indicates the general trends. The one condition which is not adequately detected is when there is a flow blockage in the fuel assembly along with an excessive bypass leakage. This particularly points out the desirability of measuring outlet temperature directly. In order to solve this problem, one could apply an additional flow baffle as shown in Figure $\mathrm{I}-1$ to isolate the temperature reading from the cold bypass leakage. The flow paths are shown for the hot flow from the fuel assembly, as well as for the leakage flows around the hexagonal surface of the fuel assembly and past the lower gate valve. The thermocouple located inside of the shroud in this arrangement is in the hot argon stream from the fuel assembly, which will not be mixed with the bypass leakage. The next phase in the design of this equipment should consider the practicality of making the requirement for outlet gas temperature measurement.

In instrumented fuel assemblies, where thermocouples are incorporated in the assembly, suitable electrical connections could be made. This would produce the desired fuel (cladding) temperature directly.

Table I-1

APPROXIMATE READINGS OF INSTRUMENTS

UNDER VARIOUS NORMAL AND ABNORMAL CONDITIONS

Location

Number

(refer to

Figure 2-2)

$(1)^{*}$

$(2)^{*}$

(3)

(4)

(5)

(7)

(8)

(9)

(10)

(11)
Excessive

Bypass Leakage

Conditions $240 \mathrm{cu} \mathrm{ft} / \mathrm{min}$

Around Fuel Assembly $192 \mathrm{cu} \mathrm{ft} / \mathrm{min}$

$600^{\circ} \mathrm{F}$

$400^{\circ} \mathrm{F}$

-3.2 psig

$400^{\circ} \mathrm{F}$

-4.2 psig

$100^{\circ} \mathrm{F}$

$$
\begin{gathered}
\Delta \mathrm{P}=0.1 \text { psi } \\
250^{\circ} \mathrm{F} \\
-3 \text { psig }
\end{gathered}
$$

$100^{\circ} \mathrm{F}$

$250^{\circ} \mathrm{F}$

0.5 psig

$90^{\circ} \mathrm{F}$

$300 \mathrm{cu} \mathrm{ft} / \mathrm{min}$

$100^{\circ} \mathrm{F}$

$0.1 \mathrm{psi}$

$200^{\circ} \mathrm{F}$

-2.2 psig

$320 \mathrm{cu} \mathrm{ft} / \mathrm{min}$
Failure of .

Hose

Hose

$60 \mathrm{cu} \mathrm{ft} / \mathrm{min}$

Fuel Assembly

Blockage

$160 \mathrm{cu} \mathrm{ft} / \mathrm{min}$

$700^{\circ} \mathrm{F}$

$510^{\circ} \mathrm{F}$

-6 psig

-5.4 psig

-6.6 psig

$100^{\circ} \mathrm{F}$

0.04 psi

$0.1 \mathrm{psi}$

0.04 psi

$100^{\circ} \mathrm{F}$

-3.5 psig

$90^{\circ} \mathrm{F}$

$250^{\circ} \mathrm{F}$

$0.2 \mathrm{psig}$

$85^{\circ} . \mathrm{F}$

$300^{\circ} \mathrm{F}$

-3.5 psig

$100^{\circ} \mathrm{F}$

$300^{\circ} \mathrm{F}$

0.2 psig

$85^{\circ} \mathrm{F}$
Fuel Assembly

Blockage and

Excessive Bypass

Leakage

$160 \mathrm{cu} \mathrm{ft} / \mathrm{min}$

$700^{\circ} \mathrm{F}$

$420^{\circ} \mathrm{F}$

-5 psig

\section{*Not measured}

$$
100^{\circ} \mathrm{F}
$$

$200 \mathrm{cu} \mathrm{ft} / \mathrm{min}$

Note: Mcaouremonto are for flow, temperature, and pressure 


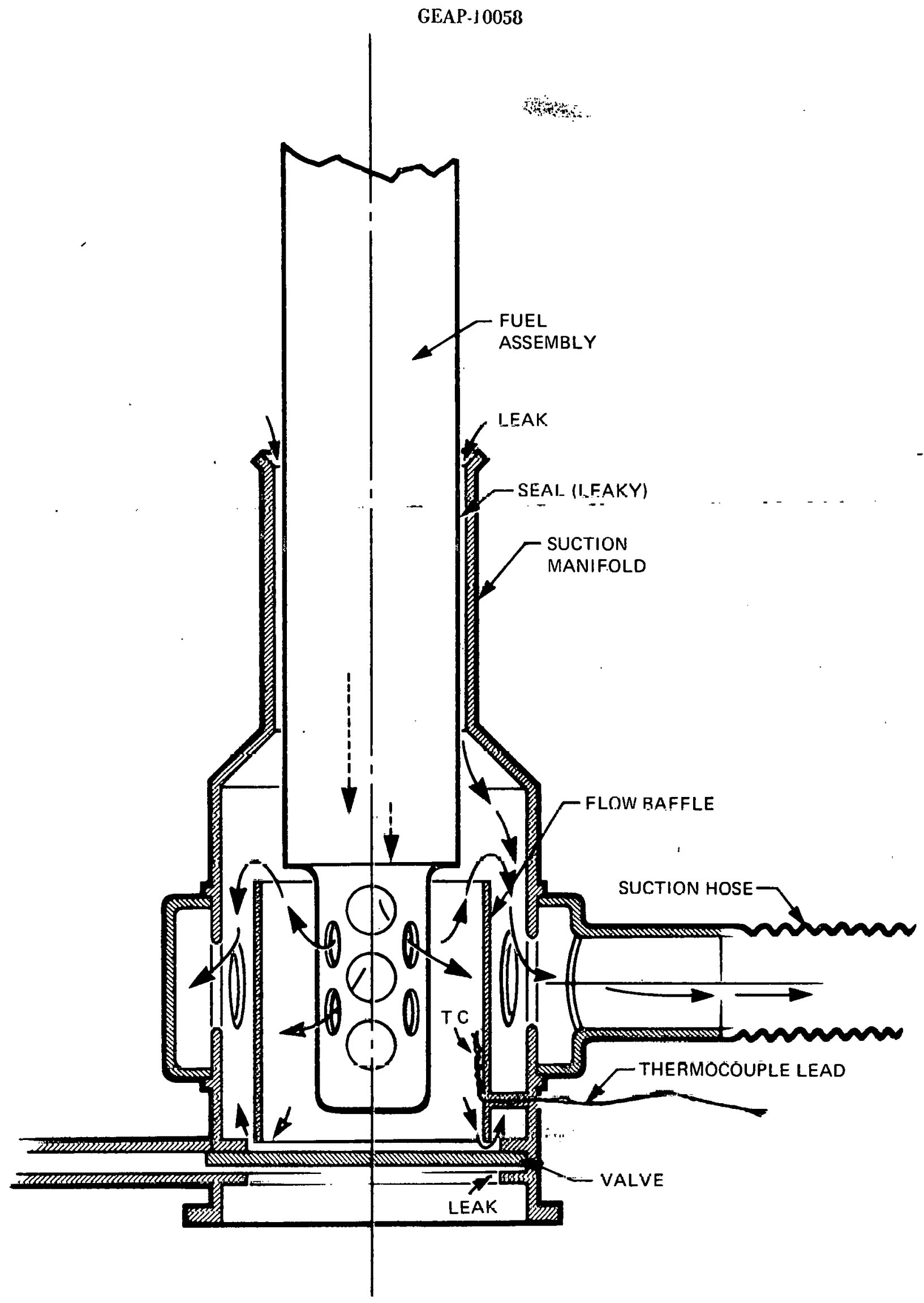

Figure I-1. Added Flow Baffle in Suction Manifold to Permit Accurate Measurement of Outlet Temperature 


\section{APPENDIX J}

\section{RELATED EXPERIENCE IN GAS COOLING}

Past experience in the gas cooling of fuel assemblies from sodium-cooled reactors is limited to fuel assemblies having a heat generation rate considerably lower than $20 \mathrm{~kW}$. For instance, EBR-II fuel is normally transferred after 15 days cooling when the total heat generation rate is only $1.2 \mathrm{~kW}$.* At this low heat generation rate, heat removal is much less critical, and total removal of cooling would not result in cladding melting.

Fuel transfer from the EBR-II reactor is accomplished with a large shielded cask with an internal reeirculating gas (argon) system which transfers heat from a fuel assembly to the inner surface of the shielding. Heat is transferred from the inner surface of the shielding by conduction into the shield. The gas circulation is pumped by a positive displacement rotary lobe-type pump

Because of the very low heat generation of the EBR-II fuel assembly, failure of the gas circulating system may be tol-

* Bernstein, G. J., Chilenskas, A. A., Malecha, R. F.. "Interbuilding Fuel Transfer Coffin for the EBK-II Reactor," September 1964, (ANL.-6934). erated if repair can be made within approximately 13 minutes. As a last resort, the fuel assembly can be cooled by filling the cavity with liquid mercury.

Handling EBR-II fuel assemblies in the air cell of the fuel cycle facility can be accomplished by means of a cooling grapple (Ref 1 ). This device is designed to remove up to 3 $\mathrm{kW}$ of heat by suction of air into a flexible hose attached to the upper end of the fuel assembly. Although this device operates with upward suction of air instead of down ward suction of argon and it can accommodate only $3 \mathrm{~kW}$ of heat, it is essentially similar to the suction cooling system proposed in this report.

Other sodium-cooled fast reactors tend to be less oriented toward complex gas-cooled handling systems if they are not designed specifically as test reactors as is the FFTF Longer decay times and less stringent cladding temperature limits considerablv reduce the cooling requirements. **

** The entire proceedings of the 16th Conference on Remote Systems Technology, American Nuclear Society, 1969. 


\section{INTERFACES}

Item Service

1. Facility Arrangement

2. Fuel Component Cooling

3. Fuel Component Transfer

1. Argon Atmosphere

5. Instruments

\section{Interfacing System}

No.

Title

$21 \quad$ Structures

35 First Core Fuel Assembly Component

41 Reactor Refueling System

82 Inert Gas Receiving and Processing System

93 Plant Instrumentation

\section{Interfacing Area}

Examination facility structures and arrangement, cell penetrations and equipment access.

Cooling of driver fuel assemblies during transfer, handling and examination.

Transfer fuel assemblies to fuel examination facility from FTR. Cooling applied when received. Transfer fuel assemblies from fuel examination facility to FTR for reinsertion.

Provision and maintenance of a filtered, cooled and purified argon atmosphere in the cell bank. Provision and maintenance of the out-of-cell portion of the gas cooling system(s).

Provision and maintenance of out-of-cell monitoring and recording instrumentation. 


\section{ACKNOWLEDGMENTS}

The following personnel made a substantial contribution to the work described in this report:

Design Drafting: F. L.. Suckow. L. Senif $\therefore$. . .
Thermal Hydraulic Analysis: D. L. Wilmer, W. A. Sangster

Development Program: A. S. Gibson

\section{DISTRIBUTION}

Pacific Northwest Laboratory

FFTF Project

P.O. Box 220

Richland, Washington 99352

Attn: Supervisor of Configurations

Contract 